\title{
The CHPRC Columbia River Protection Project Quality Assurance Project Plan
}

\author{
NJ Fix
}

November 2008

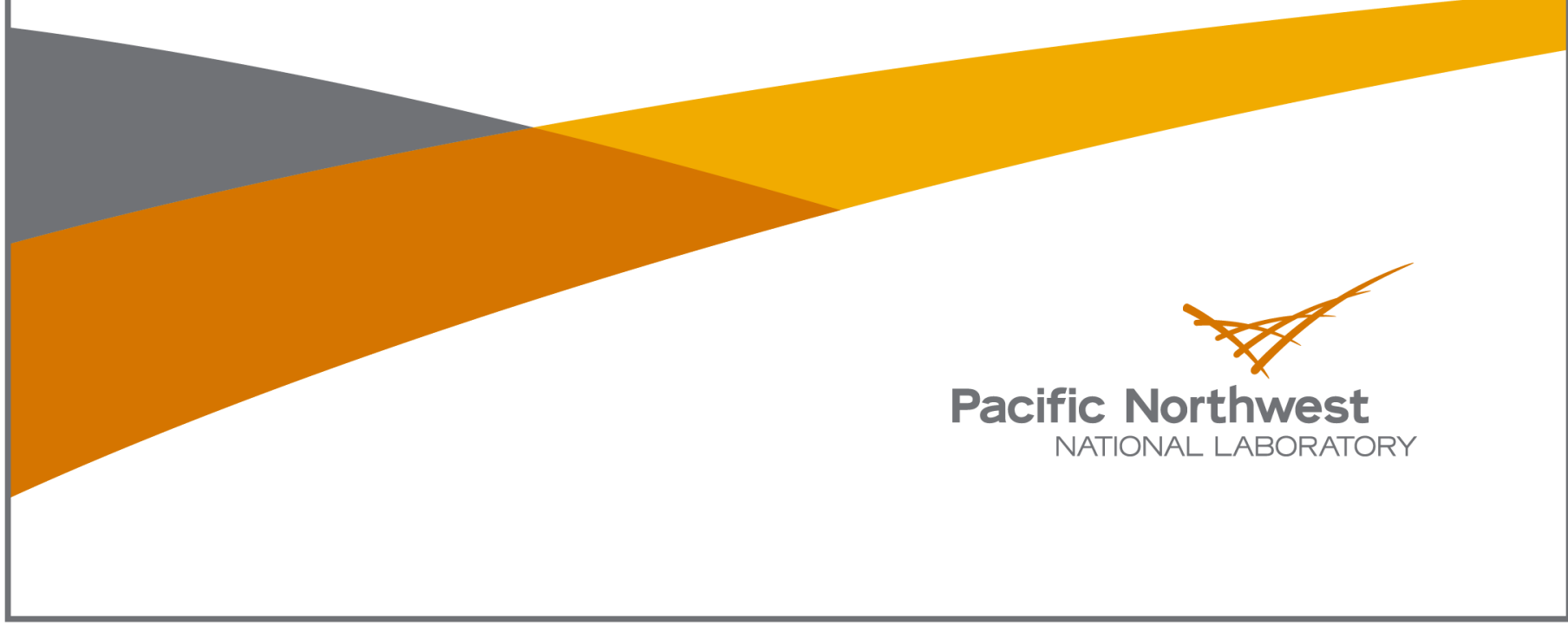




\title{
DISCLAIMER
}

This report was prepared as an account of work sponsored by an agency of the United States Government. Neither the United States Government nor any agency thereof, nor Battelle Memorial Institute, nor any of their employees, makes any warranty, express or implied, or assumes any legal liability or responsibility for the accuracy, completeness, or usefulness of any information, apparatus, product, or process disclosed, or represents that its use would not infringe privately owned rights. Reference herein to any specific commercial product, process, or service by trade name, trademark, manufacturer, or otherwise does not necessarily constitute or imply its endorsement, recommendation, or favoring by the United States Government or any agency thereof, or Battelle Memorial Institute. The views and opinions of authors expressed herein do not necessarily state or reflect those of the United States Government or any agency thereof.

\author{
PACIFIC NORTHWEST NATIONAL LABORATORY \\ operated by \\ BATTELLE \\ for the \\ UNITED STATES DEPARTMENT OF ENERGY \\ under Contract DE-AC05-76RL01830
}

Printed in the United States of America
Available to DOE and DOE contractors from the
Office of Scientific and Technical Information,
P.O. Box 62, Oak Ridge, TN 37831-0062;
ph: (865) 576-8401
fax: $(865) 576-5728$
email: reports@adonis.osti.gov

\author{
Available to the public from the National Technical Information Service, \\ U.S. Department of Commerce, 5285 Port Royal Rd., Springfield, VA 22161 \\ ph: (800) 553-6847 \\ fax: $(703) 605-6900$ \\ email: orders@ntis.fedworld.gov \\ online ordering: http://www.ntis.gov/ordering.htm
}




\section{The CHPRC Columbia River Protection Project Quality Assurance Project Plan}

NJ Fix

November 2008

Prepared for

the U.S. Department of Energy

under Contract DE-AC05-76RL01830

Pacific Northwest National Laboratory

Richland, Washington 99352 



\title{
The CHPRC Columbia River Protection Project Quality Assurance Project Plan
}

\author{
Project \# 55109
}

Prepared by

Pacific Northwest National Laboratory

Richland, Washington 99352

Issue Date: November 2008

Approval:

DD Dauble, Product Line Manager

Environmental Science \& Technology

JS Fruchter, Project Manager

CHPRC Columbia River Protection Project
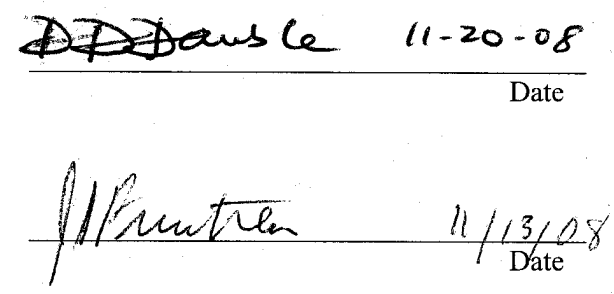

Concurrence:

NJ Fix, Project Quality Engineer Quality Assurance Services

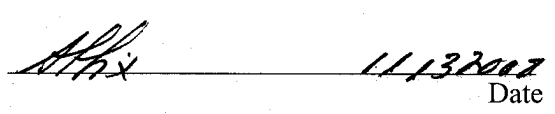





\begin{tabular}{|l|l|l|l|l|}
\hline \multicolumn{5}{|c|}{ Quality Assurance Project Plan Revision History } \\
\hline \multicolumn{4}{|c|}{ Formal revisions to this Quality Assurance Project Plan are listed below. } \\
\hline Rev. \# & \multicolumn{1}{|c|}{ Comments } & Rev. Date & $\begin{array}{l}\text { Effective } \\
\text { Date }\end{array}$ & Approvals \\
\hline 0 & $\begin{array}{l}\text { Initial Quality Assurance Project } \\
\text { Plan release. }\end{array}$ & N/A & $5 / 12 / 08$ & \\
\hline 1 & $\begin{array}{l}\text { Revised to reflect change in client } \\
\text { name, contract structure, contract } \\
\text { releases, and SBMS changes. }\end{array}$ & $11 / 08$ & $11 / 08$ & \\
\hline
\end{tabular}





\section{Executive Summary}

Pacific Northwest National Laboratory researchers are working on the CHPRC Columbia River Protection Project (hereafter referred to as the Columbia River Project). This is a follow-on project, funded by CH2M Hill Plateau Remediation Company, LLC (CHPRC), to the Fluor Hanford, Inc. Columbia River Protection Project. The work scope consists of a number of CHPRC funded, related projects that are managed under a master project (project number 55109). All contract releases associated with the Fluor Hanford Columbia River Project (Fluor Hanford, Inc. Contract 27647) and the CHPRC Columbia River Project (Contract 36402) will be collected under this master project. Each project within the master project is authorized by a CHPRC contract release that contains the project-specific statement of work. Project-specific budgets and costs are tracked separately for reporting purposes.

This Quality Assurance Project Plan provides the quality assurance requirements and processes that will be followed by the Columbia River Project staff. This plan is based on the requirements in the $E P A$ Requirements for Quality Assurance Project Plans (QA-R-5) (EPA/240/B-01/003 ${ }^{1}$ ) in accordance with the Hanford Federal Facility Agreement and Consent Order (commonly referred to as the Tri-Party Agreement [Ecology et al. 1989²]); DOE Order 414.1C, Quality Assurance 3 , and 10 Code of Federal Regulations 830, Subpart A, "Quality Assurance Requirements." The Price-Anderson Amendments Act ${ }^{5}$ also applies to this project.

\footnotetext{
${ }^{1}$ EPA/240/B-01/003. 2001. EPA Requirements for Quality Assurance Project Plans (QA/R-5). U.S. Environmental Protection Agency, Washington, D.C.

${ }^{2}$ Ecology - Washington State Department of Ecology, U.S. Environmental Protection Agency, and U.S. Department of Energy. 1989, as amended. Hanford Federal Facility Agreement and Consent Order. Document No. 89-10, Olympia, Washington.

${ }^{3}$ DOE Order 414.1C. 2005. Quality Assurance. U.S. Department of Energy, Washington, D.C.

${ }^{4} 10$ CFR 830, Subpart A, "Quality Assurance Requirements." U.S. Code of Federal Regulations.

${ }^{5}$ Price-Anderson Amendments Act. Energy Policy Act of 2005. Title VI-Nuclear Matters, Subtitle A Price-Anderson Act Amendments, Section 601 et. seq. Public Law 109-58, as amended. 42 USC 15801 et seq.
} 



\section{Acronyms and Abbreviations}

ASTM

ATS

CAWSRP

CD

CERCLA

CFR

CHPRC

CMP

DA

DOE

DQO

DVD

EPA

ERICA

ERT

ESL QAP

FY

GB

GS

HASQARD

HEIS

ICN

IRI

ISRM

LOI

LRB

M\&TE

MDA

MDL

NIST

NQA

OJT

OU

PAAA

PNNL

PMP

QA
American Society for Testing and Materials

Assessment Tracking System

Conducting Analytical Work in Support of Regulatory Programs

compact disk

Comprehensive Environmental Response, Compensation, and Liability Act Code of Federal Regulations

CH2M Hill Plateau Remediation Company, LLC

Configuration Management Plan

design authority

U.S. Department of Energy

data quality objectives

digital versatile disc

U.S. Environmental Protection Agency

Electronic Records and Information Capture Architecture

electrical resistivity tomography

Environmental Sciences Laboratory Quality Assurance Plan

fiscal year

gigabytes

General Services

Hanford Analytical Services Quality Assurance Requirements Documents

Hanford Environmental Information System

Interim Chance Notice

Information Resource Inventory

In Situ Redox Manipulation

letter of instruction

Laboratory record book

measuring and test equipment

minimum detectable activity

method detection limits

National Institute of Standards and Technology

Nuclear Quality Assurance

on-the-job-training

operable unit

Price-Anderson Amendments Act

Pacific Northwest National Laboratory

Project Management Plan

quality assurance 


$\begin{array}{ll}\text { QAPjP } & \text { Quality Assurance Project Plan } \\ \text { QC } & \text { quality control } \\ \text { QL } & \text { quality level } \\ \text { RCRA } & \text { Resource Conservation and Recovery Act } \\ \text { SAP } & \text { Sampling and Analysis Plan } \\ \text { SBMS } & \text { Standards-Based Management System } \\ \text { SC } & \text { Safety Class } \\ \text { SDD } & \text { Software Design Description } \\ \text { SOW } & \text { statements of work } \\ \text { SRS } & \text { Software Requirements Specification } \\ \text { SS } & \text { Safety significant } \\ \text { TSD } & \text { treatment, storage, and disposal } \\ \text { TRIM } & \text { Total Records Information Management } \\ \text { USGS } & \text { U.S. Geological Survey } \\ \text { VOC } & \text { volatile organic constituent } \\ \text { VVP } & \text { Verification and Validation Plan } \\ \text { VVR } & \text { Verification and Validation Review } \\ \text { VVPR } & \text { Verification and Validation Plan Review } \\ \text { WAC } & \text { Washington Administrative Code } \\ \text { WBR } & \text { workstation backup and restore } \\ \text { WPA } & \text { Work Package Authorization } \\ & \end{array}$




\section{Contents}

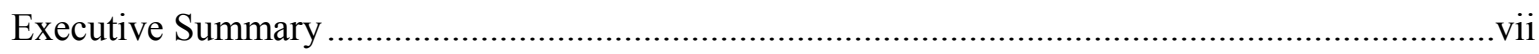

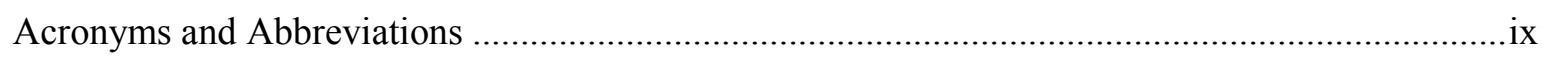

1.0 Quality Assurance Project Plan Distribution .....................................................................

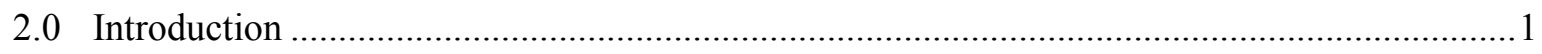

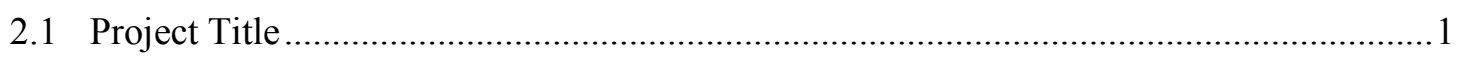

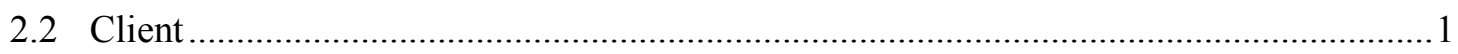

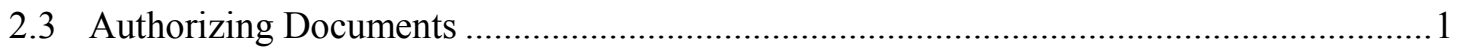

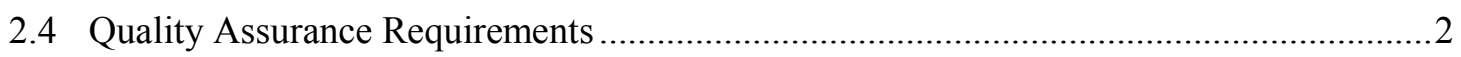

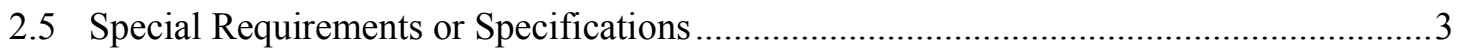

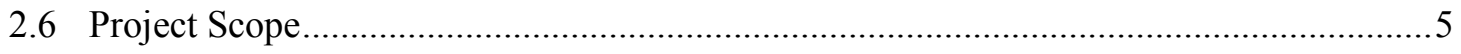

2.6.1 300-FF-5 CERCLA Support (Contract 36402, Release 32)...................................5

2.6.2 300 Area Uranium Test (CHPRC Contract 36402, Release 34) ............................6

2.6.3 Apatite Infiltration Gallery Pilot Investigation at 100-NR-2 (CHPRC Contract

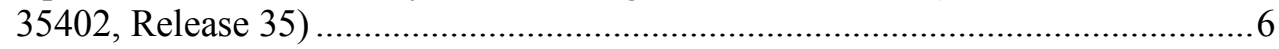

2.6.4 Strontium-90 Phytoremediation Investigation for 100-NR-2 (CHPRC Contract

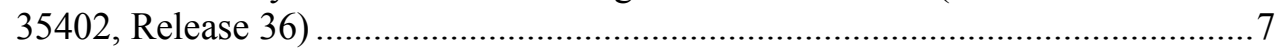

2.7 Change Control (Scope, Schedule, Budget).............................................................

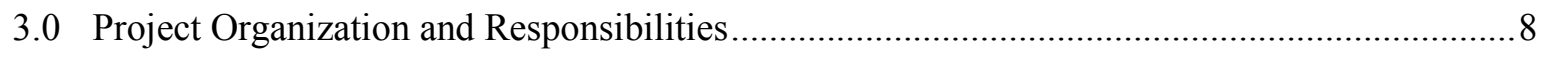

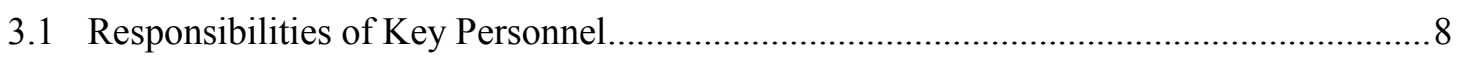

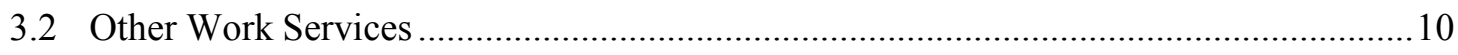

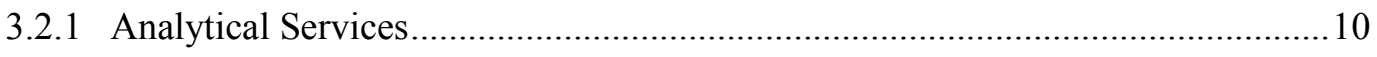

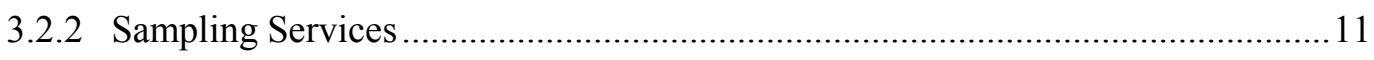

3.2.3 Well Drilling, Sampling, and Construction Services .........................................11

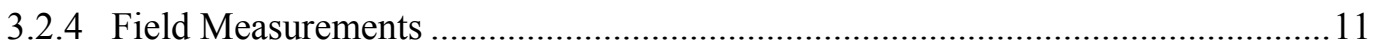

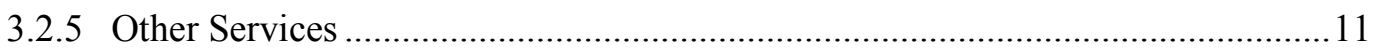

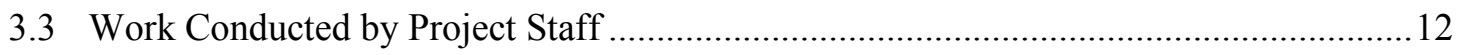

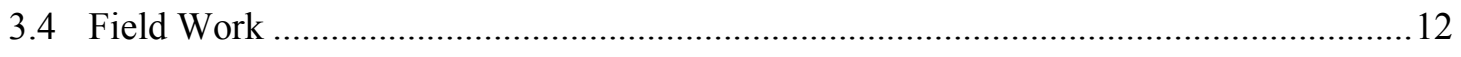

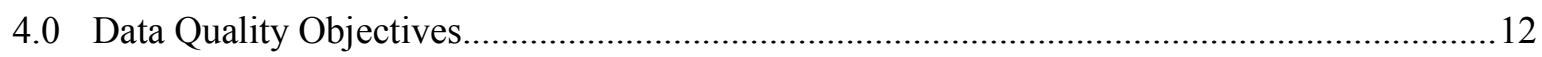

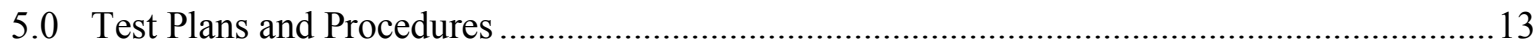

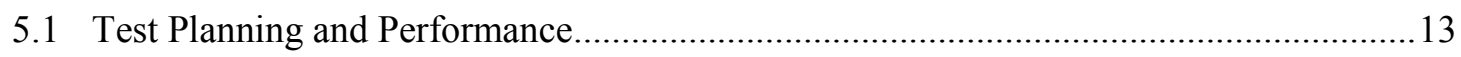

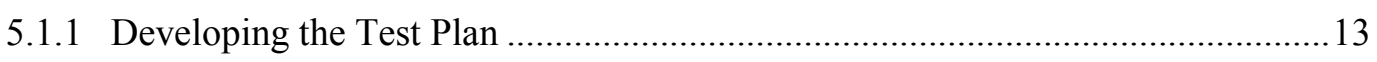

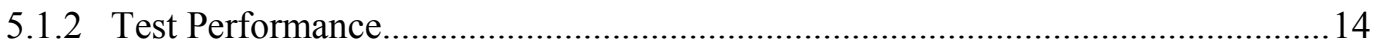

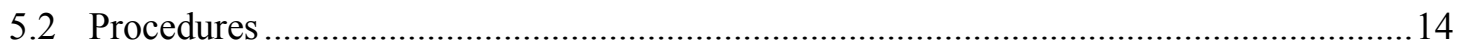

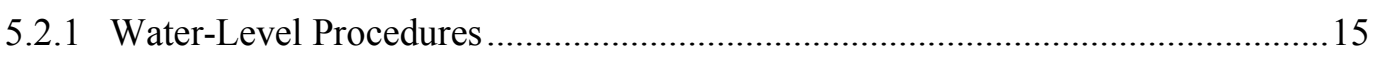

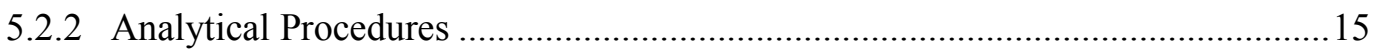

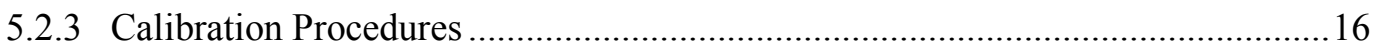

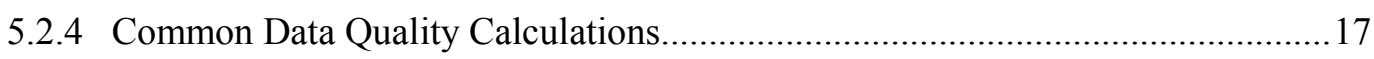


5.2.5 Well Drilling and Construction Procedures .....................................................17

5.2.6 Water and Sediment Sample Collection Procedures ...........................................17

5.2.7 Receiving and Handling Samples................................................................... 17

5.2.8 Sediment Physical Analysis Procedures.......................................................... 18

5.2.9 Sediment Core Analysis Procedures ................................................................ 18

5.2.10 Geophysical Measurement Procedures ............................................................ 18

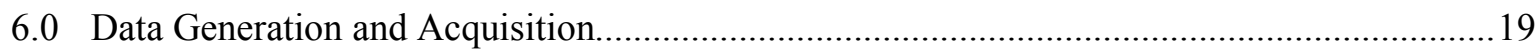

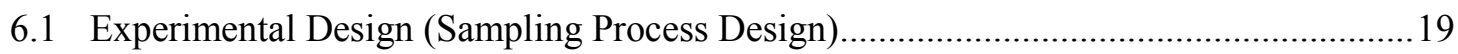

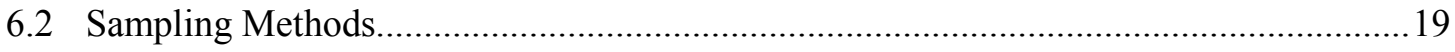

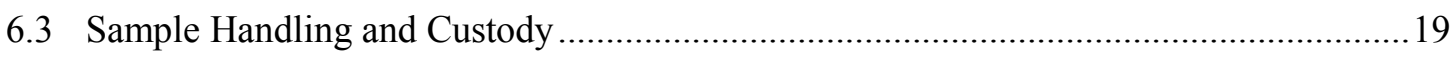

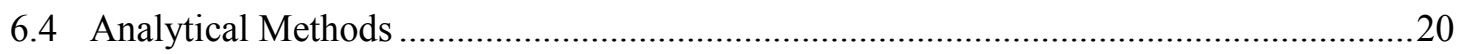

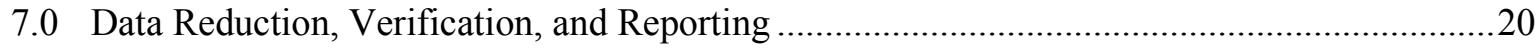

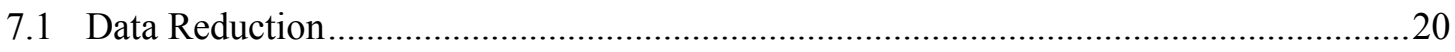

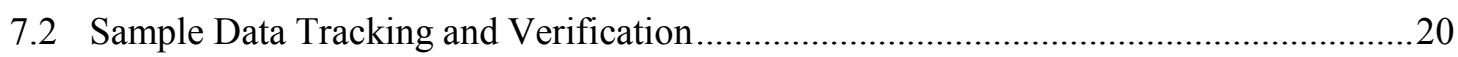

7.3 Sample Data and Tracking for Soil and Sediment Samples........................................... 21

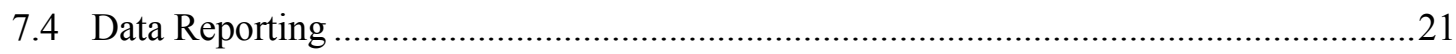

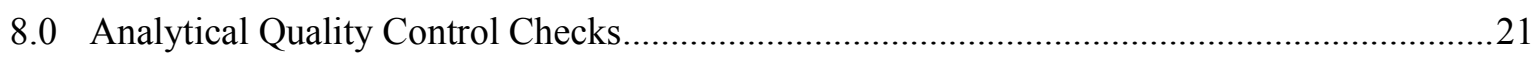

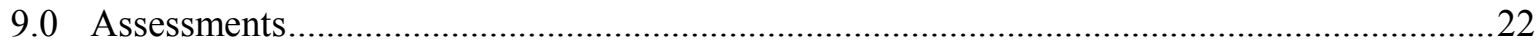

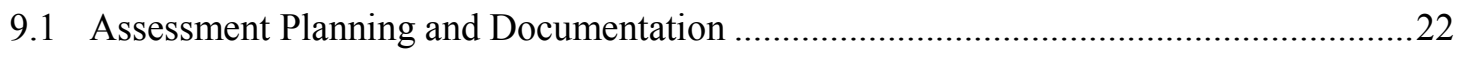

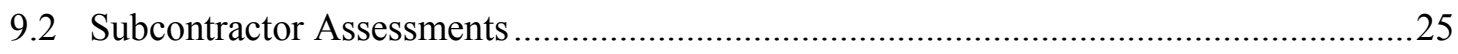

10.0 Preventive Equipment Maintenance ..............................................................................25

11.0 Specific Routine Procedures Used to Assess Data Precision, Accuracy, and Completeness ...25

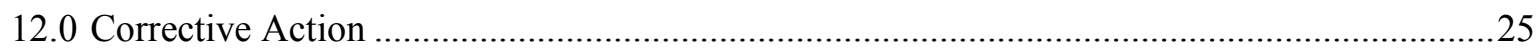

12.1 Project Corrective Actions Resulting from Assessments ..............................................25

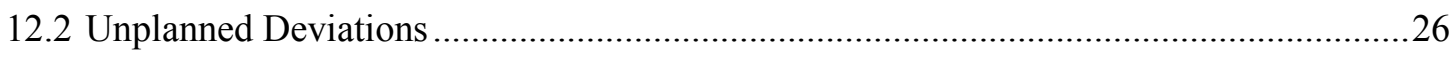

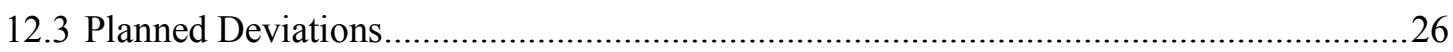

12.4 Measuring and Test Equipment Calibration Discrepancies .........................................26

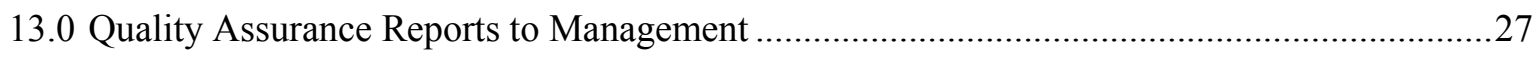

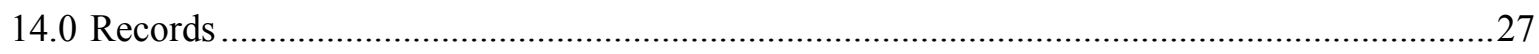

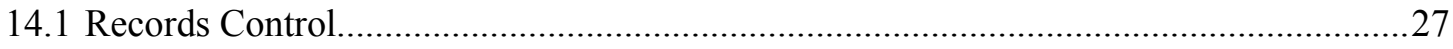

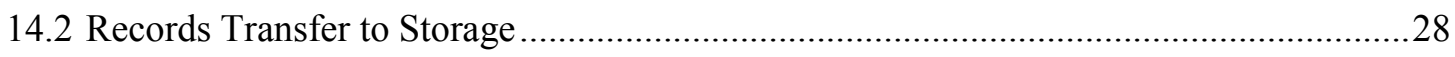

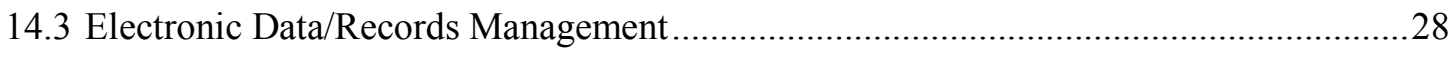

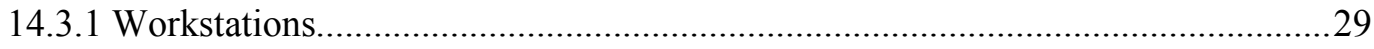

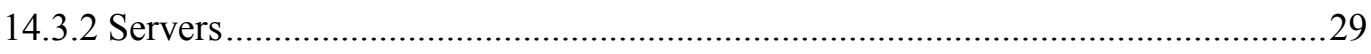

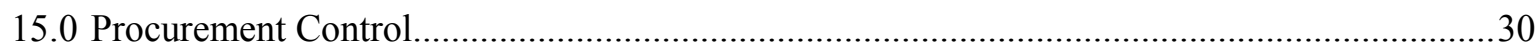

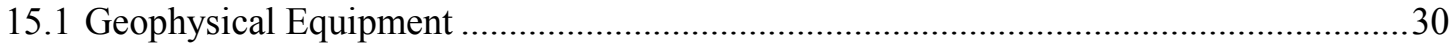

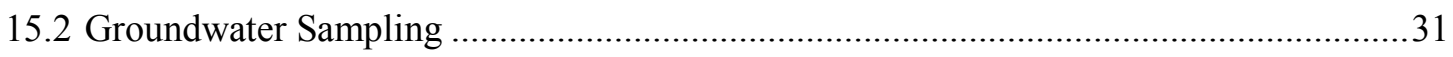

15.3 Groundwater and/or Sediment Analytical Measurements.............................................. 31

15.4 Other Hanford Site Contractor Services....................................................................... 31 


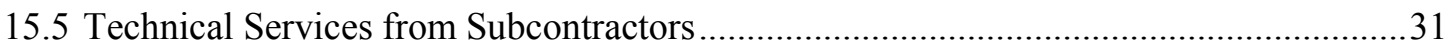

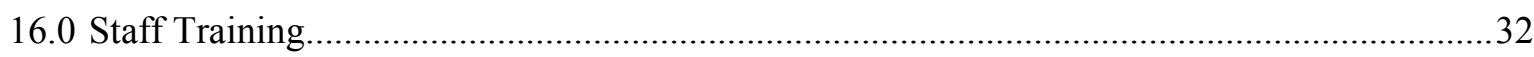

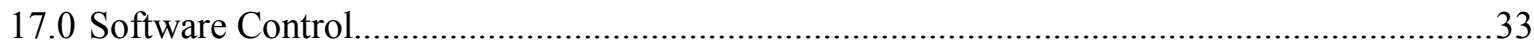

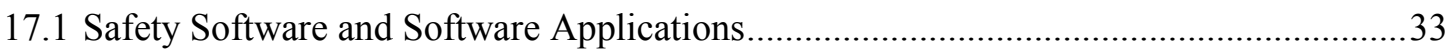

17.1.1 Minimum Documentation Requirements .............................................................. 34

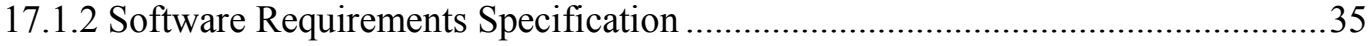

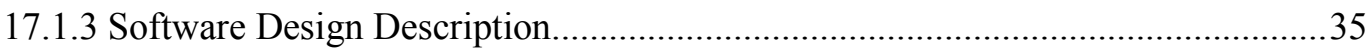

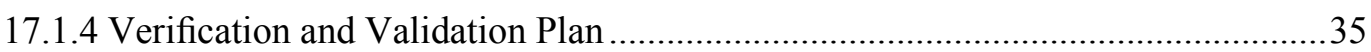

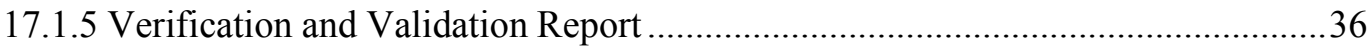

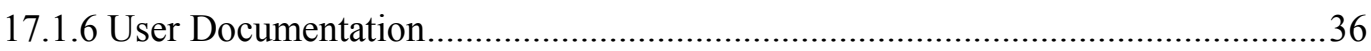

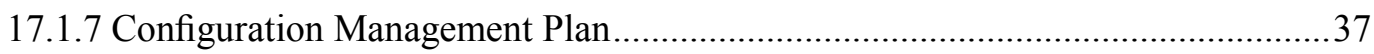

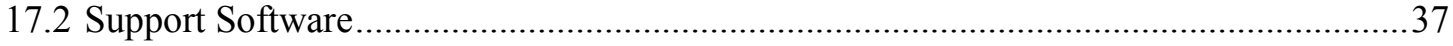

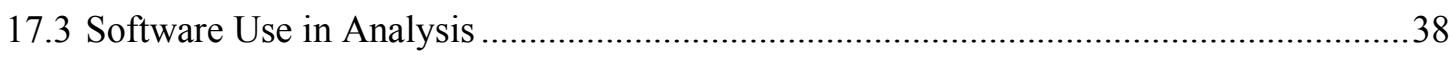

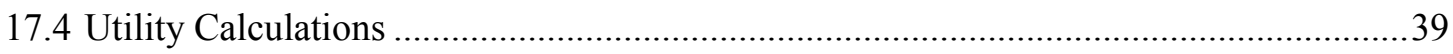

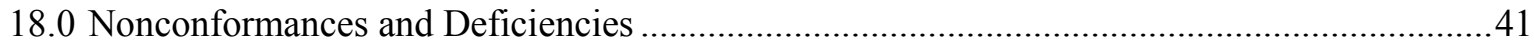

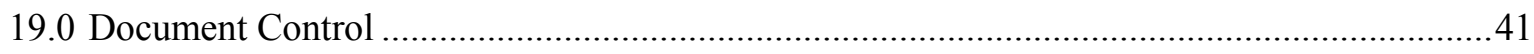

19.1 Quality Assurance Project Plan Control...................................................................... 41

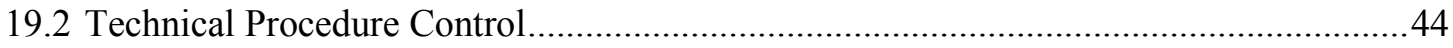

19.3 Administrative Procedure/Instruction Preparation and Control ......................................44

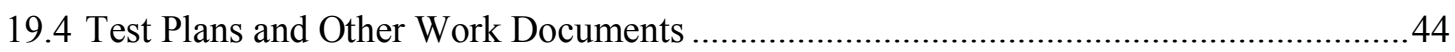

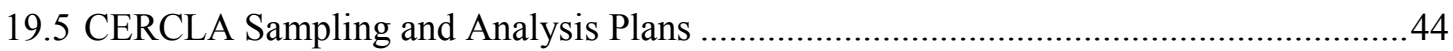

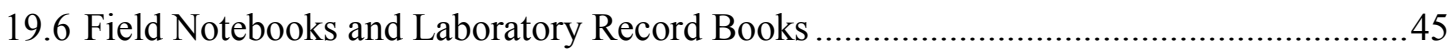

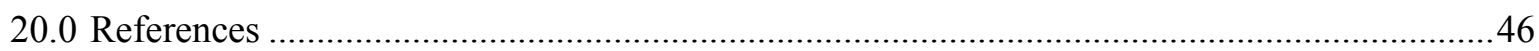

Appendix A - The CHPRC Columbia River Protection Project Quality Control Plan................... A.1

Appendix B - Experimental and Modeling Procedures for the Projects..................................... B.1

\section{Figures}

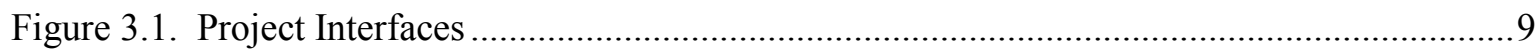

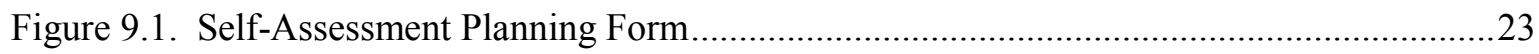

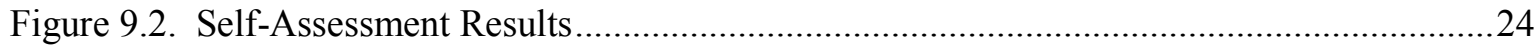

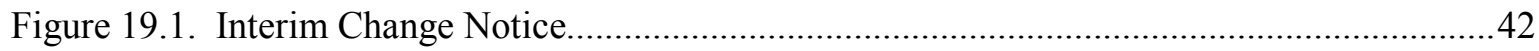

\section{Tables}

Table 2.1. Columbia River Project Contract Releases .............................................................

Table 17.1. Software Risk Management Examples .................................................................. 40 



\subsection{Quality Assurance Project Plan Distribution}

Pacific Northwest National Laboratory (PNNL) document control will distribute this Quality Assurance Project Plan (QAPjP) internally to PNNL, the U.S. Department of Energy (DOE) Reading Room, and the Hanford Technical Library. The Master Project Manager will determine the final PNNL and external distribution list. Also, the QAPjP will be published in accordance with the Standards-Based Management System (SBMS) subject area, "Publishing Scientific and Technical Information"

(PNNL 2007b).

\subsection{Introduction}

\subsection{Project Title}

The title of this project is as follows: The CHPRC Columbia River Protection Project (herein after called the Columbia River Project).

\subsection{Client}

The client is CH2M Hill Plateau Remediation Company, LLC (CHPRC), located in Richland, Washington.

\subsection{Authorizing Documents}

Work is authorized by specified contract releases to Contract 36402 that are received from and revised by CHPRC throughout the fiscal year. The contract releases are managed by the Master Project Manager in concert with the individual project managers and the project specialist. The contract releases effective October 1, 2009 are shown in Table 2.1. Additional contract releases with related scope may be added throughout the fiscal year.

Table 2.1. Columbia River Project Contract Releases

\begin{tabular}{cccc}
\hline $\begin{array}{c}\text { CHPRC } \\
\text { Release } \\
\text { Number }\end{array}$ & $\begin{array}{c}\text { PNNL } \\
\text { Project } \\
\text { Number }\end{array}$ & Contract Release Title & $\begin{array}{c}\text { PNNL Project } \\
\text { Manager }\end{array}$ \\
\hline 32 & 56173 & 300 -FF-5 CERCLA Support & RE Peterson \\
34 & 55797 & 300 Area Uranium Test & VR Vermeul \\
35 & 55165 & Apatite Infiltration Gallery Pilot Investigation at 100-NR-2 & VR Vermeul \\
36 & 55161 & Strontium-90 Phyto Remediation Investigation for 100-NR-2 & RJ Fellows \\
\hline
\end{tabular}




\subsection{Quality Assurance Requirements}

The project contained within the Columbia River Protection Project's quality assurance (QA) program shall comply with the requirements in the U.S. Environmental Protection Agency's (EPA) EPA Requirements for Quality Assurance Project Plans (QA/R-5) (EPA/240/B-01/003) in accordance with the Hanford Federal Facility Agreement and Consent Order, commonly referred to as the Tri-Party Agreement (Ecology et al. 1989). The QAPjP is also based on the QA requirements of DOE Order 414.1C, "Quality Assurance," and 10 Code of Federal Regulations (CFR) 830, Subpart A, "Quality Assurance Requirements," as delineated in the PNNL SBMS. The projects are subject to the Price Anderson Amendment Act (PAAA) as defined in the PNNL PAAA Program and implemented through the SBMS subject area, "Reporting Noncompliances with DOE Requirements for Nuclear Safety and Worker Safety and Health" (PNNL 2008h). Additionally, the Columbia River Project management staff have determined the Hanford Analytical Services Quality Assurance Requirements Documents ([HASQARD]; DOE/RL-96-68) apply to analytical work on the projects. The PNNL document for implementing HASQARD is Conducting Analytical Work in Support of Regulatory Programs (CAWSRP) located at http://etd.pnl.gov/docs/conducting-work/index.stm.

In addition, CHPRC has imposed quality levels upon various projects contained within this Master Project. For clarity and consistency the CHPRC quality levels are defined as follows:

"The environmental graded approach shall be documented in project documents such as Quality Assurance Project Plans (QAPjPs) or Sampling and Analysis Plans (SAPs) as appropriate and as required by the governing standard(s) (e.g., EPA QA/R-5).

a. Quality level 1 shall be assigned to Safety Class (SC) items and associated services and items and associated services posing a high project risk.

b. Quality Level 2 shall be assigned to Safety Significant (SS) items and associated services not designated as Quality Level 1 and items and associated services posing a medium project risk.

c. Quality Level 3 shall be assigned to:

1. General Service (GS) items and associated services posing a low project risk, but, based on engineering evaluation, require additional controls beyond standard commercial practices.

2. Any item or service with the potential to cause radiological harm (in the present or future) which has not been designated as Quality Level 1 or 2.

3. Items where independent verification is required by a national consensus standard (e.g., AWS D1.1; ANSI B31.3; ASME Section VIII) which have not been designated as Quality Level 1 or 2.

NOTE: The following are examples of GS items and services which may be graded as Quality level 3, based on an engineering evaluation:

- Item or service performs a safety function (defense-indepth), but does not meet the criteria for SC or SS.

- Item or service performs a function to minimize impact to the environment. 
- Item or service performs a function to minimize damage to the facility or its critical equipment.

d. Quality Level 0 shall be assigned to GS items and services procurements not designated as Quality Level 1, 2 or 3. The controls inherent in standard commercial practices are acceptable." (HNF-PRO-259, Revision 11).

NQA-1-2000 standards always apply to CHPRC Quality Level 1 and 2 items, but CHPRC can impose NQA-1-2000 standards on Quality Level 3 or 0 products. The additional requirements must be specifically identified in the statements of work (SOWs) and/or contract releases received from CHPRC.

\subsection{Special Requirements or Specifications}

DOE Orders 435.1, Radioactive Waste Management; 5400.5, Radiation Protection of the Public and Environment; and 450.1, Environmental Protection Program, apply to the treatability studies to ensure activities related to the radioactive materials and samples are protective of human health and the environment, and fulfill PNNL environment and stewardship requirements. Compliance and waste cleanup timetables and implementation milestones are established in the Tri-Party Agreement (Ecology et al. 1989) to achieve compliance with remedial action provisions of the Comprehensive Environmental Response, Compensation and Liability Act (CERCLA) and the treatment, storage, and disposal (TSD) unit regulations and corrective action provisions promulgated under the Resource Conservation and Recovery Act (RCRA).

Field experiment and sampling and analysis plans (see Sections 4.0 and 5.0) will be based on applying the data quality objectives (DQO) process, in accordance with the Guidance on Systematic Planning Using the Data Quality Objectives Process (QA/G-4) (EPA/240/B-06/001). Field experiment and sampling and analysis plans are reviewed and approved at the project level and updated as necessary.

Computer modeling and database activities for the project shall comply with the software requirements as specified in the SBMS subject area, "Software" (PNNL 2007d) and "Safety Software" (PNNL 2008i). Specific safety software and software requirements for the activities are based on a graded approach and are described in more detail in Section 17.0.

CHPRC has also stated in Appendix D of its Soils and Groundwater Remediation Project (S\&GRP) QAPjP that " $[\mathrm{t}]$ he following are required to be at least QL3 per HNF-PRO-259:

a. Items where independent verification is required by a national consensus standard (AWS D1.1, ANSI B31.3, ASME Section VIII.

b. Items or services with the potential to cause radiological harm.

c. Items and services that require additional controls beyond commercial practices based upon engineering evaluation.

- Items or services that perform a safety function (defense in depth)

- Items or services that minimize impact to the environment 
- Items or services that perform a function to minimize damage to a facility or its critical equipment

3. Additional Items and Services in S\&GRP that are GS QL 3 include:

a. Design and construction of critical elements of in situ groundwater barriers.

b. Testing of instruments used to demonstrate regulatory compliance.

c. Procurement of services or standards used to calibrate instruments used to collect environmental data.

d. Self performance or procurement of services for well drilling, well construction, well decommissioning, geotechnical test borings, environmental investigation wells, geophysical logging.

e. Well maintenance (maintenance where well modification is involved requiring the filing of a resource protection well report).

f. Procurement of selected materials used in self performed well construction (permanent well screens and casing).

g. Procurement of services related to analytical laboratory work.

h. Procurement of services related to groundwater/vadose modeling.

i. Procurement of services related to acquisition of Geophysical data.

j. Procurement of items or services that could directly impact data quality (e.g. sample bottles).

k. Procurement of services to develop CERCLA and RCRA response action documents that include tasks requiring the use of computational and analytical software, including spreadsheets. Such tasks would include, but not be limited to vadose zone and groundwater contaminant fate and transport modeling and the conduct of human health, ecological, and protection of groundwater risk assessments. CERCLA and RCRA response action documents include the administrative and technical plans and reports developed to support the selection and implementation of removal and/or remedial actions.

1. Procurement of selected items that are susceptible to counterfeiting as described in DOE G 414.1-3 Suspect/Counterfeit Items Guide (e.g., graded fasteners, circuit breakers, ratchet type tie downs and other items as determined by the DA [Design Authority] and QA). Purchase orders for such items shall include clauses or statements regarding procurement of potentially suspect or counterfeit items and shall require receipt inspection" (S\&GRP QAPjP, current revision).

These criteria will affect PNNL deliverables submitted to CHPRC as part of this project. 


\subsection{Project Scope}

The scope of this QAPjP provides PNNL staff with the program-specific planning, execution, assessment of work, and controls necessary to provide products/solutions and services of the highest quality consistent with project risks, in accordance with SBMS subject area, "Battelle Policies and Standards" (PNNL 2006a) and the needs, expectations, and resources of the client.

Management processes, including planning, scheduling/execution, and providing resources for work to provide project deliverables based on risk, safety, life cycle, and complexity are described in the CHPRC Columbia River Protection Project Management Plan (Project No. 55109, current revision).

DOE has conducted interim groundwater remedial activities on the Hanford Site since the mid-1990s for several groundwater contamination plumes. DOE established the Columbia River Protection Supplemental Technologies Project in 2006 to evaluate alternative treatment technologies. The project was scheduled to run for two years. Three of the original six technologies evaluated were selected in FY 08 by Fluor Hanford, Inc. for follow-on work. Fluor Hanford, Inc. was succeeded as a Hanford Site contractor by CHPRC beginning in FY 09 and these projects were transferred to CHPRC with one additional project to become the basis of the CHPRC Columbia River Protection Project. These initial projects are described in the following sections.

\subsubsection{0-FF-5 CERCLA Support (Contract 36402, Release 32)}

CHPRC requested that PNNL support activities relating to meeting CERCLA objectives for the 300 Area. PNNL is tasked to develop the 300 Area Work Plan and support the systematic planning efforts. The initial efforts are to support the completion of the systematic planning efforts, finalize the Work Plan annotated outline, and develop the Work Plan. This work plan will incorporate lessons learned from the 100 Areas work plan and systematic planning activities. Additional activities include supporting the ongoing groundwater monitoring in the area. The scope of this project consists of the following tasks:

As part of the 300 Area Remedial Investigation/Feasibility Study (RI/FS) Work Plan, PNNL shall prepare and lead the effort to develop an overarching Project Plan that will describe the scope of the project through the project vision, objectives, and work breakdown structure. It shall define when the work task and subtasks will be completed and by whom. It shall describe how the project team will ensure that the project meets quality requirements. It shall illustrate how the project team plans to manage changes and risks so impact on the project is minimal. Finally, it shall identify key project elements that need to be closed-out as the project progresses and the corresponding team members responsible for the close-out of those tasks.

PNNL shall then prepare the Work Plan in accordance with DOE's environmental guidance Remedial Investigation/Feasibility Study (RI/FS) Process, Elements, and Techniques Guidance (DOE/EH94007658) and EPA's Guidance for Conducting Remedial Investigations and Feasibility Studies Under CERCLA (EPA/540/G-89/004). The Work Plan integrates activities for both the Source and Groundwater Operable Units (OUs) and their associated contactors Washington Closure Hanford, LLC and CHPRC.

PNNL will also support ongoing groundwater monitoring and data evaluation for the 300 Area and two remote burial grounds, 618-10 and 618-11. The monitoring plan will be updated as needed, water samples will be analyzed for specified constituents on a semi-annual basis (some samples collected 
quarterly), the results will be evaluated on a regular, periodic basis as they are received from the lab, and the results and interpretations will be reported in the annual Hanford Site Groundwater Monitoring Report. Monitoring plans and data interpretations for this project will be coordinated with similar activities associated with the 300 Area Process Trenches, a RCRA Waste Management Area (WMA) located in the OU.

\subsubsection{Area Uranium Test (CHPRC Contract 36402, Release 34)}

PNNL shall support the CHPRC 300-FF-5 Groundwater OU work by continuing laboratory studies on uranium mineralogy and vadose zone polyphosphate transport and performing field test and the necessary steps to support the field test.

Source treatment in the deep vadose zone will accelerate the natural attenuation of uranium to thermodynamically stable uranium-phosphate minerals, enhancing the performance of the proposed polyphosphate remediation within the 300 Area aquifer. Data obtained from the laboratory study will be used to develop implementation cost estimates, identify implementation challenges, and investigate the ability of the technology to meet remedial objectives. This information will be used to establish the viability of the method and determine how best to implement the technology in the field. An approach will be to apply this technology to a selected field site within the 300 Area.

\subsubsection{Apatite Infiltration Gallery Pilot Investigation at 100-NR-2 (CHPRC Contract 35402, Release 35)}

A significant amount of strontium-90 $\left({ }^{90} \mathrm{Sr}\right)$ mass $(40 \%$ to $70 \%)$ in sediments along the Columbia River shoreline at 100-NR-2 is held in the variably-saturated sediments within the zone of water table fluctuation, which is driven by seasonal and diurnal variability in Columbia River Stage. It is also likely that there is a higher concentration of ${ }^{90} \mathrm{Sr}$ in low conductivity zones in this variably saturated zone, due to less water flushing. Development of a strategy to infiltrate a Ca-citrate- $\mathrm{PO}_{4}$ solution through this zone is currently funded by DOE EM-22. Small-scale and 2-D infiltration experiments conducted in the laboratory $(<1.5 \mathrm{~m})$ have shown that infiltration of a Ca-citrate- $\mathrm{PO}_{4}$ solution can be used to emplace apatite precipitate in specific locations in the vadose zone. Using a constant concentration and moderate to rapid infiltration rates of Ca-citrate- $\mathrm{PO}_{4}$ solution, apatite formation occurred primarily in the upper third of the infiltration zone. However, manipulation of the solution concentration and infiltration rate resulted in apatite precipitate formation over the lower half of the infiltrated zone, which is desired for field scale application. The project will utilize laboratory scale results available to date and conduct preliminary field-scale water infiltration experiments to evaluate: a) strategy needed to infiltrate solution (i.e., trench, drip emitters, soaker hose, etc.) and b) type of equipment needed to monitor infiltrating plume (i.e., geophysical electrical resistance tomography [ERT] measurements, neutron access tubes, and surface geophysical techniques). This work element will be designed to evaluate, over a specified range of infiltration rates, both the road bed material's ability to infiltrate the water and the water content profile developed over the targeted portion of the vadose zone (i.e., the interval from just below the fill material to the water table). The range of infiltration rates selected for evaluation will be based on results from the EM-22 funded bench- and intermediate-scale Ca-citrate- $\mathrm{PO}_{4}$ infiltration studies.

This field-scale experiment will be conducted downstream of the apatite permeable reactive barrier (PRB) location, outside the area where upper Hanford formation sediments are expected to be 
contaminated with significant amounts of ${ }^{90} \mathrm{Sr}$. The specific tasks assume that, given the limited technical risk associated with this activity, a stand-alone treatability test plan will not be required. Instead, this activity would be conducted under the Apatite PRB Treatability Test Plan (see DOE/RL 2005-96), with test specifics documented in a field test instruction.

During development of the infiltration design, PNNL will evaluate various options for implementing and monitoring a distributed infiltration experiment. PNNL will be responsible for designing, instrumenting, and conducting the test.

In addition to the infiltration gallery test, PNNL will also investigate the effectiveness of the apatite injection performed in 2005 and 2006. The 100-N sediment samples (100 g) collected during installation of six Ringold-only injection wells, an area which has previously been treated with low concentration formulation Ca-citrate- $\mathrm{PO}_{4}$ injections, will be tested to determine if measurable quantities of apatite precipitate are present and whether these apatite contents effectively reduce $\mathrm{Sr}$ and/or ${ }^{90} \mathrm{Sr}$ mobility.

\subsubsection{Strontium-90 Phytoremediation Investigation for 100-NR-2 (CHPRC Contract 35402, Release 36)}

The concentration of ${ }^{90} \mathrm{Sr}$ exceeds EPA drinking water standards in some places along the Columbia River shore in the Hanford Site 100-N Area. Currently, there is no effective method to stop ${ }^{90} \mathrm{Sr}$ associated with the riparian zone sediments from leaching into the river. Phytoremediation is a remediation technology in which plants are used to extract or isolate soil contamination. In the case of

${ }^{90} \mathrm{Sr}$, the plant incorporates the contaminant into its above ground biomass, which is later harvested. The technology is not be used alone, but employed with other methods of remediation (e.g., apatite barrier or monitored natural attenuation) as a polishing step specific to the very near river shoreline.

Six separate Tasks are required to perform this study. The first, Project Management, is an ongoing component for the life of the program. The second, Plant Maintenance and Collection, includes actual management of the site (weeding, monthly fertilization) with two harvests of new growth stems and leaves (June-July, and prior to leaf drop in October), and collection of groundwater samples at bi-monthly intervals. The third, Sample Analysis and Reporting, includes sample preparation (drying, weighing, grinding), sample analysis (ICP-AES analysis of plant and groundwater), data reduction, and reporting. The fourth, Aphid Studies, will follow the exposure and analysis of green peach aphids (Myzus persicae) and their digestive exudates, or honeydew, for ${ }^{90} \mathrm{Sr}$ content. The fifth task will be another feeding study with either the western yellowstriped armyworm (Spodoptera praefica) or the alfalfa looper (Autographa californica) and the analysis will continue through the different growth stages to the adult moths. The sixth task will include a common herbivorous insect the field cricket (Gryllus campestrus), another food source to larger predators.

\subsection{Change Control (Scope, Schedule, Budget)}

The project scope, schedule, and budget baseline are compiled, tracked, and reported using a project control system in accordance with DOE direction.

Changes in work scope, schedule, or budget may be necessary during the year. Changes may be requested of subcontractors by PNNL that will result in a change to the SOWs due to revisions of work 
scope, schedule, and/or budget. These changes will be documented in revisions or addendums to the existing SOWs and a PNNL Subcontracts Supplement Form shall be completed.

Administrative changes requested of subcontractors that are approved by Task Leaders may be made by verbal or electronic message authorization. Written documentation of the verbal changes and electronic messages should be maintained in the permanent project files. These changes may only be made if technical work scope and budget are not affected significantly.

\subsection{Project Organization and Responsibilities}

Line authority, QA authority, support within PNNL, and client interfaces are shown organizationally in Figure 3.1. The responsibilities of key PNNL personnel are summarized in Section 3.1. Changes to organizational/interface structures shown in Figure 3.1 that do not reflect a change in the overall scope of the activities, or a change of requirements will not require a QAPjP revision and will be incorporated into the next required revision of the QAPjP.

\subsection{Responsibilities of Key Personnel}

- Project Manager - Provides overall direction to task managers and project personnel within PNNL necessary to accomplish project objectives; coordinates and executes project controls associated with scope, schedule, and budget baselines; reports on project status; assures the project is staffed with technically qualified personnel; serves as primary client interface to assure that customer expectations are met in terms of quality, cost, and schedule; and assures the QAPjP is implemented.

- Technology Task Leaders - Oversees task-specific planning, control, communications, and progress reporting; prepares scope, resource needs, cost baseline, and deliverables; assures quality and timeliness of the work, in accordance to plans, policies, and procedures; provides monthly reports; and interfaces with DOE, other contractors, subcontractors, and other Task Leaders.

- Technology Principal Investigators - Provides task-specific technical plans, communications, and progress reporting to the Task Leader; prepares technical details of the task plan; assures technical quality of the work; supports the Task Leader to assure work is performed on schedule, within budget, and in accordance to plans, policies, and procedures; assigns and directs work of project staff; and interfaces with DOE, other contractors, subcontractors, and other investigators.

- Project Quality Engineer - Provides guidance and direction to Project Manager, Task Leads, and project staff within PNNL on PNNL QA Program requirements; performs assessments to assure quality of the work; develops, updates, and approves QAPjP; and reviews and approves appropriate work plans and procedures.

- Other Project Staff - Assures technical quality of the work and that it is performed on schedule, within budget, and in accordance with plans, policies, and procedures; reports concerns (such as unsafe conditions) and stops work as necessary. 


\section{Organization for the CH2M Hill Plateau \\ Remediation Company, LLC Columbia River Protection Project}

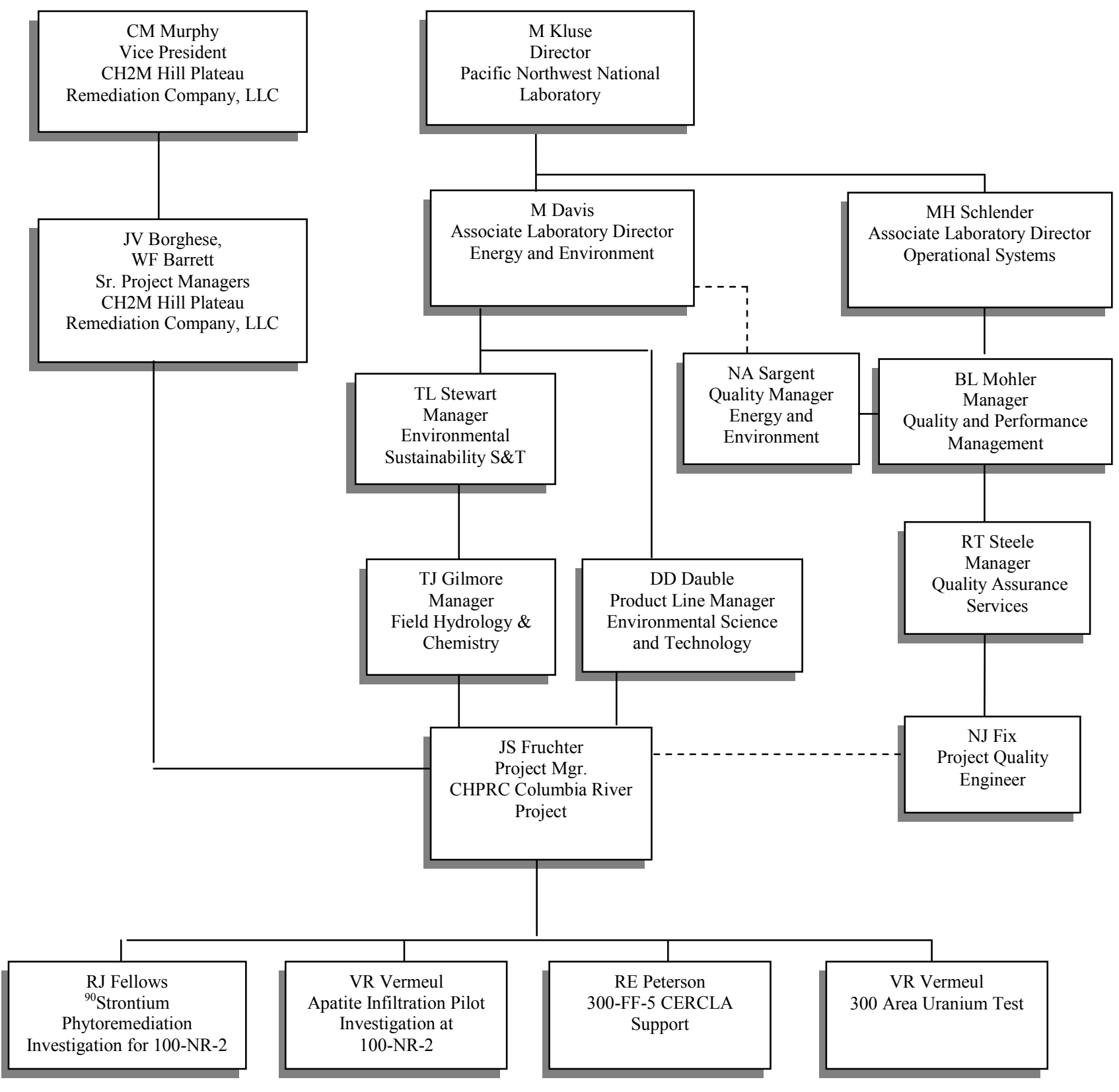

Figure 3.1. Project Interfaces 


\subsection{Other Work Services}

Other work services for various portions of project work will be through the purchasing process. General scope of work, work requirements, specifications, and QA requirements are communicated via a contracting mechanism to various subcontractors (see Section 15.0). SOWs to subcontractors used for groundwater and sediment sample analysis will require compliance with HASQARD (DOE/RL-96-68) and/or the EPA Requirements for Quality Assurance Project Plans (QA/R-5) (EPA/240/B-01/003); 10 CFR 830, Subpart A, "Quality Assurance Requirements;" DOE Order 414.1C, Quality Assurance; and specific requirements to be achieved by appropriate quality documents. The SOW will include instructions for inspecting/accepting supplies and consumables used for this project.

Subcontracts for drilling, sediment sampling, groundwater sampling, and associated support activities will include the following:

- CH2M Hill Plateau Remediation Company, LLC provides drilling, sediment and water sample collection related to drilling, and well construction services.

- Other subcontractors may provide civil surveys, special analytical services, or other services.

Other work services for various portions of project work will be through the purchasing process. General scope of work, work requirements, specifications, and QA requirements are communicated via a contracting mechanism to various subcontractors (see Section 15.0).

Project staff will perform sampling and measurements according to written and approved internal procedures. Analytical activities conducted by the project staff shall be conducted in accordance with written, standard operating procedures. Field measurements will be conducted in accordance with in-house operating procedures. Project staff members are responsible for preparing data reports that summarize the results of analyses, quality control data for the method used, and identification of data qualifiers. The results and raw data will be included in the project records.

\subsubsection{Analytical Services}

The analytical laboratories including commercial, onsite, and other DOE national laboratories, are responsible for preparing data reports that summarize the results of analyses and detailed data packages that include the following:

- Sample receipt and tracking documentation, including identification of the organization and individuals performing the analysis; names and signatures of the responsible analysts; sample holding time requirements; references to applicable chain-of-custody procedures; and dates of sample receipt, extraction (if applicable), and analysis.

- Quality control data, as appropriate for the methods used, including (as applicable) matrix spike/matrix spike duplicate data, recovery percentages, precision and accuracy data, laboratory blank data, and identification of any nonconformance that may have affected the laboratory's measurement system during the time period in which the analysis was performed.

- Analytical results or data deliverables, including reduced data and identification of data qualifiers and contractually defined reporting comments. 
These requirements, as well as QA and technical requirements, are specified in the SOW to the analytical laboratories. The requirements for the hard copy and electronic data received from the analytical laboratories are specified in respective analytical subcontractor SOW.

\subsubsection{Sampling Services}

The organization collecting soil or water samples, generally PNNL, is responsible for 1) obtaining the samples; 2) delivering samples to the laboratory; and 3) delivering completed paperwork to implementing sample tracking. All activities associated with the sample collection, sample handling, sample labeling, and custody of the samples in the field shall be consistent with the recommendations and protocol provided in Chapter 4, Section 4.2 through 4.4 in the RCRA Ground Water Monitoring Technical Enforcement Guidance Document (National Water Well Association 1986), Test Methods for Evaluating Solid Waste, SW-846 (EPA/SW-846, as amended), and the Handbook for Analytical Quality Control in Water and Wastewater Laboratories (EPA-600/4-79/019). Activities associated with the sample collection, sample handling, sample labeling, and custody of the samples in the field shall be consistent with the SOW.

\subsubsection{Well Drilling, Sampling, and Construction Services}

CHPRC provides well-drilling and construction subcontractors and oversight on the Hanford Site. CHPRC is responsible for 1) well drilling design specifications and contract management, 2) site preparation and documentation requirements, 3) sediment and water sample collection during drilling, 4) supporting hydrologic tests conducted during drilling, and 5) well construction, development, and sample pump installation. Well construction will meet the requirements of Washington Administrative Code 173-160. Well drilling and construction, sediment and water sampling, testing support, and associated quality requirements will be specified in the SOW to CHPRC. CHPRC may subcontract work activities, provided the requirements in the SOW and the CHPRC QA Program are met by subcontractor(s).

\subsubsection{Field Measurements}

Field measurements during well drilling will be conducted in accordance with CHPRC procedures, or other equivalent procedures, and as directed in the SOW. Project-specific test plans that have been reviewed and approved will address procedures during field experiments.

\subsubsection{Other Services}

Other subcontracted services received from CHPRC or other Hanford Site contractors may include construction of fences and enclosures, geophysical logging, etc. 


\subsection{Work Conducted by Project Staff}

Analytical activities conducted by project staff in support of the Columbia River Project shall be conducted in accordance with written standard operating procedures. Field measurements will be conducted in accordance with in-house operating procedures. Project staff members are responsible for preparing data reports that summarize the results of analyses, quality control data for the method used, and identification of data qualifiers. The results and raw data will be included in the project records.

Project staff will perform sampling and measurements according to written and approved test plans (Section 5.1), written procedures, or other written direction.

\subsection{Field Work}

Field work is executed by the Columbia River Projects. Prior to executing field work, project-specific test plans are developed, as described in Section 5. If supplemental information or individual parameters are needed to perform a test, a test instruction will be developed. The test instruction shall be reviewed by a technical reviewer.

Field work associated with task activities is conducted in accordance with the Surface Environmental Surveillance Procedures Manual (PNL-MA-580, current revision). The following procedures in PNL-MA-580 are used:

- Section 4.6 - "Specific Conductance"

- Section 4.7 - "pH Measurement"

- Section 4.8 - "Filtered Water Samples"

- Section 8.1 - "Chain-of-Custody."

\subsection{Data Quality Objectives}

The QA objectives for measurements generally applicable to technology investigations under the purview of this QAPjP are primarily related to the following: 1) the definition of appropriate methods and analytical precision and accuracy appropriate for chemical analysis of the analyte of interest; and 2) the definition of methods and limits and values for physical measurements associated with the investigation (e.g., column tests). Discussions of aqueous sample analytical objectives and analytical methods with corresponding target values for detection limits, precision, and accuracy are provided in Appendix A of this QAPjP, the Environmental Sciences Laboratory QA Plan (ESL QAP, current revision), individual test plans, and/or test procedures. The sediment analytical objectives and analytical methods with corresponding target values for detection limits, precision, and accuracy are provided in the ESL QA Plan, individual test plans, and/or test procedures. DQOs developed in accordance with Guidance on Systematic Planning Using the Data Quality Objectives Process (QA/G-4)

(EPA/240/B-06/001) will be applied. Other measurement objectives and methods with corresponding target values for detection limits, precision, and accuracy (as applicable) are provided in the specific work plans and/or the SOW for such activities. Specific data quality needs for individual investigations that are different than the requirements established herein shall be addressed within individual work plans. Other measurement considerations, accuracy requirements, units, and data recording and reporting protocols for 
instruments supporting stratigraphic characterization, aquifer testing and other types of field investigations shall be as specified in the applicable plans and/or procedures.

\subsection{Test Plans and Procedures}

Test plans and procedures are used to assure that activities affecting quality are performed consistently and correctly. Test plans are prepared by PNNL staff to conduct a single experiment or test as identified below. Formal procedures will be developed for quality-affecting work activities that are routinely performed. Additional procedures will be developed as needed.

\subsection{Test Planning and Performance}

Test plans will be used to document a single or related set of experiments or tests (e.g., hydrologic field tests, vertical sampling) work activity.

\subsubsection{Developing the Test Plan}

The test plan shall contain the following information:

- A title and/or number including date or revision.

- Dated signatures of the Preparer, Technical Lead, Project Manager or Task Lead, and Quality Representative.

- Individual page identification (page __ of __ ).

The content of each test plan depends on the scope of the test. The following is a brief description of mandatory and optional items to be considered in the preparation of the test plan:

- Purpose/Description (mandatory) - Provide a short narrative on the purpose of the experiment/test/activity.

Example: The purpose of this test is to provide hydrologic property data at polyphosphate treatability injection test wells.

- Prerequisites (mandatory) - List items, conditions, or other concerns that must be satisfied prior to beginning the test.

Example: Prior to beginning the work activity, the staff must complete special training on other plans or procedures that will be used in conjunction with the test plan, special handling or storage requirements, special access or permits, and required records that need to be generated as the result of the work activity.

- Safety (mandatory) - Describe the hazards associated with the work such as physical agents (e.g., temperature, pressure, noise, electrical); hazardous environments (e.g., confined spaces, remote locations, heat/cold stress); and hazardous materials (e.g., flammables, corrosives, highly toxic, carcinogens). Describe the methods used to mitigate the hazards that were identified (e.g., personal protective equipment, time periods away from the hazard, alarms, and location of nearest aid station). 
- Materials and Equipment (optional) - List the materials and equipment that are necessary to complete the work.

- Measuring and Test Equipment (mandatory) - List the equipment that will be used to make the measurements; include the calibration requirements, system checks, and quality control checks in this section or in the work instructions section of the test plan.

- Pretest Verification (mandatory) - Determine if certain items of a test require verification prior to their use and indicate how the verification will be done.

Example: A tracer solution containing bromine will be used throughout the test and the initial concentration shall be known. The solution shall be measured by the calibrated probe (as described above) and the concentration shall be recorded prior to injection.

- Documentation and Reporting (mandatory) - Describe where the data collected during the test should be documented (e.g., field record forms, laboratory record books (LRBs), computer database, downloaded from computer to hardcopy) or entered into the Hanford Environmental Information System (HEIS). Additionally, describe what will be reported, to whom, and the due date(s).

Test results documented in LRBs shall be reviewed semi-annually by a technically qualified individual who did not perform the work. The reviewer will verify that there is sufficient detail to retrace the investigation and confirm the results.

- Work Instructions (mandatory) - Provide step-by-step instructions and/or non-sequential instructions (whichever is more appropriate to the activity). Each step or instruction shall be as simple as possible but with sufficient detail so that individuals experienced in the technology or activity involved can easily understand. The following types of information should be considered for inclusion: administrative control hold points (i.e., where safety, quality, radiological, or other approvals or actions are required before proceeding); cautions that indicate potentially hazardous situations which, if not avoided, may result in death, injury, or damage to facilities or equipment; and notes that call attention to supplemental information that assist the user in making decisions or improving work performance.

\subsubsection{Test Performance}

Tests will be performed in accordance with the test plans, which shall be available at the work location. The Technical Lead is responsible for assuring that the current version is used to perform the work.

If changes to the test plan are required during work execution, the Technical Lead shall document the deviation and the justification or rationale for the change.

\subsection{Procedures}

Procedures will be developed in accordance with the SBMS subject area, "Procedures, Permits, and Other Work Instructions" (PNNL 2004). Project staff will perform scheduling, data verification, data processing, and data management as described in Section 6.0 and by following the applicable internal technical procedures or instructions. Also, project staff will perform groundwater sampling, field measurements, water-level measurements, and aquifer testing by following the appropriate internal technical procedures. 


\subsubsection{Water-Level Procedures}

Procedures for water-level measurements shall be written in accordance with industry accepted standards, such as guidelines prepared by the U.S. Geological Survey (1977), and updated as required for the latest advances in measuring equipment.

\subsubsection{Analytical Procedures}

The specific work plans and/or test plans identify the constituents to be analyzed. The analytical methods required may be contained within the following references:

- Test Methods for Evaluating Solid Waste (EPA/SW-846, as amended)

- Methods for Chemical Analysis of Water and Wastes (EPA-600/4-79-020)

- Methods for the Determination of Organic Compounds in Drinking Water (EPA-600/4-88-039)

- Prescribed Procedures for Measurement of Radioactivity in Drinking Water (EPA-600/4-80-032)

- Procedures for Radiochemical Analysis of Nuclear Reactor Aqueous Solutions (EPA-R4-73-014)

- Radiochemical Analytical Procedures for Analysis of Environmental Samples (EMSL-LV-0539-17).

Many radiochemical methods have not been standardized, but the procedures are documented in the laboratory-specific standard operating procedures. Aqueous sample chemical and radiological analytical methods and requirements for constituents are specified by the SOW, work plan, or other written direction. Most potential chemical constituents to be analyzed are provided in Appendix A, Table A.3 of this QAPjP and/or the Environmental Sciences Laboratory QA Plan (ESL QAP, current revision). Sediment and other media constituents to be analyzed and corresponding analytical methods and procedures will be passed on to the analytical laboratory by a SOW, work plan, or other written direction.

Potential chemical constituents to be analyzed, specific analytes of interest, as well as the corresponding standard analytical methods on which the primary analytical laboratory bases its procedures, are displayed in Appendix B. The contract to the analytical laboratories, which is administered by CHPRC, specifies the use of these procedures.

Method detection limits (MDLs) shall be determined for all non-radiochemical methods required by the project. Water MDLs shall be determined in accordance with 40 CFR 136, Appendix B "Definition and Procedure for the Determination of the Method Detection Limit-Revision 1.1." The laboratory provides MDL study results to PNNL as specified in the SOW. Required detection limits for radiochemical methods are provided in the SOW, work plan, or other written direction.

Sediment constituents to be analyzed for, as well as the corresponding analytical methods and procedures, will be passed on to the analytical laboratory via a SOW. The MDLs for sediment analysis shall be determined using the calculation provided in Chapter One of EPA/SW-846, as amended.

Technical procedures not previously documented will be developed and used as described in CAWSRP, Section 7, "Procedures." If supplemental information or individual parameters are needed to perform a test, a test instruction will be developed. The test instruction shall be reviewed by a technical reviewer and must include the following information: 
- A unique numerical designation

- Revision number

- Title

- Effective date

- Instructions - operating parameters and specific test run information such as sample size and /or composition, temperature, $\mathrm{pH}$, test duration, etc.

- Reference to controlling procedure or test plan

- Approval by author

- When well-established methods (e.g., American Society for Testing and Materials [ASTM], Soil Science Society of America, or EPA) are used, a PNNL cover page will not be provided unless there is a deviation from the established method.

Appendix B lists additional analyses and measurements with the respective procedures, methods, and other relevant information.

Administrative QA processes and procedures (e.g., chain-of-custody, custody logs, sample handling, storage and disposal, training) will be required from the onsite and offsite analytical laboratories and will be specified in the SOW.

\subsubsection{Calibration Procedures}

The requirements for calibrating field and analytical laboratory instruments and maintain traceability to national or international standard (e.g., National Institute of Standards and Technology [NIST]) is in accordance with Test Methods for Evaluating Solid Waste: Physical/Chemical Methods (EPA/SW-846, as amended) and HASQARD (DOE/RL-96-68). These requirements are passed to the subcontractors by a SOW. PNNL will periodically assess the use and effectiveness of procedures and systems for calibration of equipment with subcontractors.

Measuring and test equipment (M\&TE) used by PNNL staff to collect quality-affecting data that are calibrated by the user (Category $2 \mathrm{M} \& \mathrm{TE}$ ), or by an approved external or internal source (Category 1 M\&TE) will be in accordance with the SBMS subject area, "Calibration" (PNNL 2005a). Upon receiving calibrated equipment, staff must review the documentation for acceptability and verify the proper operation of the M\&TE and check the calibration label.

M\&TE shall be controlled as described in CAWSRP, Section 4, "Instrument Calibration," and in accordance with the SBMS subject area, "Calibration" (PNNL 2005a). Externally calibrated M\&TE, such as balances, will be calibrated in accordance with the manufacturer's tolerances unless other control limits are specified and justification is provided.

Data sheets and log book entries will be used to document pipette performance checks. Calibration reports and other calibration data will be maintained as project records. 
Quality control requirements are described in CAWSRP, Section 5, "Quality Control," and in Appendix A of this QAPjP. A few exceptions to CAWSRP requirements are considered necessary for the project, as described in the following sections.

\subsubsection{Common Data Quality Calculations}

Data quality parameters of precision, accuracy, measures of agreement, detection limits/sensitivity, and uncertainty will be calculated per the formulas in CAWSRP, Section 6, in the exhibit, "Calculations for Assessing Data Quality.” For radiochemistry analyses, the MDA is reported as the detection limit.

The CAWSRP exhibit, "Calculations for Assessing Data Quality," is a control charting tool used to monitor an ongoing/continuous process where there are sufficient data points to perform a representative statistical evaluation. The analyses performed within these projects are performed as research functions in which instrumental operating parameters may be changed to accomplish many different objectives. The frequency of instrumental operating changes does not allow accumulation of sufficient data points to properly utilize control charting as a statistical analysis tool. In lieu of control charts, instrument performance is monitored daily by the use of fixed control limits.

\subsubsection{Well Drilling and Construction Procedures}

CHPRC will obtain drilling services through its procurement process. SOWs to CHPRC specify well drilling, characterization (aquifer and sediment sampling, etc.) and construction requirements. The well drilling, sediment samples collection, groundwater samples collection, water-level measurements, and notification to perform geophysical logging/gyroscope well deviation survey is the responsibility of CHPRC. These activities will be performed in accordance with CHPRC procedures and/or subcontractor procedures (e.g., conducting geophysical logging/gyroscope well deviation survey). CHPRC Health and Safety, and QA procedures and waste management procedures will be followed during the drilling activity.

\subsubsection{Water and Sediment Sample Collection Procedures}

Sediment and water samples collected during drilling will be collected by or under the direction of CHPRC, and in accordance with CHPRC or subcontractor procedures. The quality requirements for sampling activities, including chain-of-custody, storage, and records requirements are specified in the work plan or test plan.

\subsubsection{Receiving and Handling Samples}

Direction for sample receipt, handling, and storage is provided in CAWSRP, Section 3, "Receiving and Handling Samples," and in the SBMS subject area, "Sample Handling, Archival, and Disposal" (PNNL 2007c).

Chain-of-custody for samples will be documented using a chain-of-custody form. An example of a chain-of-custody form is provided as an exhibit in CAWSRP. Each PNNL facility is a secured area, restricted to authorized personnel only. Chain-of-custody will be documented for moving samples from one facility to another, but not for moving samples within a secured facility. 
The samples to be received from other PNNL groups are materials from various field investigations. Documentation of unique sample and subsample identifications will be maintained for samples received from other PNNL groups and for other samples generated from tests conducted by the project. The documentation may consist of entries in LRBs or data sheets.

Disposition of unused materials may include returning the material to another group at PNNL, the client, or disposal at PNNL. Material returned to the client will be documented by a chain-of-custody. Material disposed of at PNNL will be documented by standard waste paperwork (forms). See the SBMS subject area, "Waste, Managing" (PNNL 2008j).

\subsubsection{Sediment Physical Analysis Procedures}

Sediment physical analyses including moisture content, particle-size distribution, hydraulic conductivity, water retention, water content, bulk density, particle density, and matric potential will be performed as directed in the test plan by PNNL staff. These procedures are contained in the internal Procedures for Groundwater Investigations (PNL-MA-567). For some studies, well-established methods, (e.g., ASTM, Soil Science Society of America, or EPA) are sometimes used, and additional documentation is not needed unless there is a deviation from the established method.

\subsubsection{Sediment Core Analysis Procedures}

Sediment core analyses and column experiments will be performed by PNNL staff as directed in the test plan. Procedures are contained in the individual test plans, which will either provide a procedure or reference an existing procedure.

\subsubsection{Geophysical Measurement Procedures}

Geophysical analyses may be used for data collection and analysis as part of the Columbia River Project. Geophysical techniques currently planned for use include the following:

- Electrical resistivity tomography (ERT)

- Cross-borehole seismic

- Neutron probes

- Cross-borehole ground penetrating radar.

These measurements will be conducted by PNNL staff or subcontractors, as appropriate. Measurements conducted by PNNL staff shall be performed as directed in the test plan. In addition, procedures are contained in the individual test plans, which will either provide a procedure or reference an existing procedure. Measurements conducted by subcontractors shall be performed as directed in a SOW issued by PNNL and in accordance with the subcontractor's procedures.

Currently, there exists no ASTM or community-accepted QA/QC standards for ERT. However, EPA and the U.S. Geological Survey (USGS) have developed "best practices" recommendations for both resistivity tomography field procedures and data analysis (Johnson et al. 2008). The test plans developed for implementation of ERT processes shall document the collection of reciprocal or repeat data to 
quantify measurement errors; selection of data-collection parameters, such as number of stacks and time windows; checks for outlier data and bad electrodes or channels; and selection of inversion parameters to prevent incorrect fitting of data.

\subsection{Data Generation and Acquisition}

\subsection{Experimental Design (Sampling Process Design)}

The data generation and data collection designs for each of the treatability study projects are described in the individual work plans and sampling and analysis plans.

Sampling processes to support the treatability studies will be in accordance with the waste management area sampling design, based on the regulatory requirements (e.g., RCRA or CERCLA) and applying the DQO process in accordance with Guidance on Systematic Planning Using the Data Quality Objectives Process ( $Q A / G-4)(\mathrm{EPA} / 240 / \mathrm{B}-06 / 001)$. A description of these processes will be included in sampling and analysis plans along with the number of samples, when to sample, number of sample locations, number of quality control samples (field replicates, etc.), analysis methods and QC criteria, and the groundwater level measurements.

\subsection{Sampling Methods}

The procedures for collecting samples and identifying the sampling methods and equipment, including any implementation requirements, sample preservation requirements, decontamination procedures, and materials needed for projects involving physical sampling, are described in the projectspecific work plans and procedures. Specific performance requirements for the methods are also described. If a failure in the sampling or measurement system occurs, documentation of and recovery from the failure will be documented in the project-specific LRB. The Principal Investigator for the project is responsible for ensuring corrective actions are effective and appropriately documented.

Preparation and decontamination of sampling equipment, including the disposal of decontamination by-products; the selection and preparation of sample containers, sample volumes, and preservation methods; and maximum holding times for sample extraction and/or analysis is treatability-study topic specific. These processes will be managed in accordance with EPA/SW-846 (as amended), or PNNL-specific procedures, as applicable. Waste generated as a result of the activities will be handled in accordance with the SBMS subject areas, "Treatability Studies" (PNNL 1999) and "Waste, Managing" (PNNL 2008j).

\subsection{Sample Handling and Custody}

Water samples will be collected in accordance with CHPRC and/or PNNL-approved project-specific procedures. Custody of the samples in the field and receipt at the laboratory will be documented on the chain-of-custody forms in accordance with PNNL procedures. Shipping and transporting of the samples will be handled by CHPRC in accordance with CHPRC procedures and federal regulations. If PNNL is 
responsible for sample shipping and transporting, samples will be handled in accordance with PNNL procedures and the SBMS subject area, "Hazardous Materials, Packaging and Shipping" (PNNL 2007a).

\subsection{Analytical Methods}

The sampling and analysis plan for each site will identify the sample constituents and the analytical method as described in Section 5.2.2. The sampling package will be generated by an internal procedure, which identifies such data as the analytical methods used and sample identification on the chain-ofcustody form. The chain-of-custody form and samples are provided to the appropriate analytical laboratory.

\subsection{Data Reduction, Verification, and Reporting}

\subsection{Data Reduction}

Data measured during the Columbia River Project investigations are compiled, evaluated, and documented as described in the following sections. Samples and associated analyses will be scheduled and tracked to assure successful sample collection. Selected data may be loaded into the Hanford Environmental Information System (HEIS) database, as identified in the respective test plan.

Verification of analytical data provided by laboratories is performed in accordance with Appendix A of this QAPjP. Results are reviewed to assure the reliability and validity of the field and laboratory measurements based on accuracy, precision, and detection limits. Representativeness, completeness, and comparability may also be evaluated for overall quality. These parameters are evaluated through laboratory QC checks, replicate sampling and analyses, analysis of blind standards and blanks, and interlaboratory comparison. Acceptance criteria are established for each of these parameters in Appendix A of this QAPjP, the Environmental Sciences Laboratory QA Plan (ESL QAP, current revision), and/or in specific test plans. When a parameter is outside the criteria, corrective actions are taken to prevent a future occurrence and any data impacted are appropriately identified. If appropriate, the review will assess results of the quality control evaluation as defined in the internal procedure QC-5, "Groundwater Data Validation and Process" (see PNL-MA-567), and review results are documented as stated in the test plan.

\subsection{Sample Data Tracking and Verification}

The process for tracking and scheduling sampling and analysis requirements, sampling field activities, chains-of-custody, and laboratory analysis is managed using a variety of electronic data management tools. Groundwater data are reviewed after they are generated to assure the reliability and validity of the field and laboratory measurements collected for groundwater samples. The reliability and validity of the measurements are based on accuracy, precision, and detection limits. Representativeness, completeness, and comparability may also be evaluated for overall quality. These parameters are evaluated through laboratory QC checks (e.g., matrix spikes, laboratory blanks), replicate sampling and analyses, analysis of blind standards and blanks, and interlaboratory comparisons. Acceptance criteria are established for each of these parameters in Appendix A of this plan. When a parameter is outside the 
criteria, corrective actions are taken to prevent a future occurrence and any data impacted are

appropriately identified. Reports documenting the QC evaluation results are discussed in Section 8.0.

\subsection{Sample Data and Tracking for Soil and Sediment Samples}

Completed data packages for soil and sediment samples will be verified by qualified PNNL personnel. Verification will consist of verifying required deliverables for completeness, required QC results, chain-of-custody forms, and case narratives that describe any issues related to the sample analyses for all data packages. Verification may also include evaluating and qualifying results based on holding times, method blanks, matrix spikes, laboratory control samples, laboratory duplicates, and chemical and tracer recoveries, as appropriate to the methods used. No other verification, validation, or calculation checks will be performed. At least $10 \%$ of all data types (i.e., volatile organic constituents [VOCs], semivolatile organic constituents [semi-VOCs], metal, etc.) will be verified. Verification will be documented on checklists to be that will be included in the project files.

\subsection{Data Reporting}

Data measured during the projects are compiled, evaluated, and documented as described below. When the data review identifies suspect data, those data are investigated to establish whether they reflect true conditions or an error.

Requirements for reporting analytical data are described in CAWSRP, Section 8, "Reporting Analytical Data." All data reported shall be traceable to the M\&TE and procedure (including procedure revisions) or test plan used, and if the reported results are quantitative, a valid calibration. The analyst shall sign or initial and date the data reports unless the results printed by the instrument include identification of the analyst and date. A staff member other than the person who performed the work, and who is knowledgeable in the area being reviewed, shall review the data before results are reported.

Interpretative data, test results, and reports will be released through the information release process in accordance with the SBMS subject area, "Publishing Scientific and Technical Information"

(PNNL 2007b).

\subsection{Analytical Quality Control Checks}

Analytical QC checks are performed on internal and external samples. A summary of QC check samples is outlined in Appendix A of this QAPjP, the Environmental Sciences Laboratory QA Plan (ESL QAP, current revision), and/or in specific test plans. Internal QC data are generated when the analytical laboratory prepares QC samples to monitor the quality of its analyses.

The QC activities needed for sampling, laboratory (internal and external) and field analysis, or measurement technique will be defined in the appropriate treatability study or project test plans. For each required QC activity, the associated method, acceptance criteria, and corrective action will be listed. Also included for the field and laboratory QC activities are the use of blanks, duplicates, matrix spikes, laboratory control samples, and surrogates in the plans. The project specific QA Plans also identify the procedure, formulae, or references for calculating the percent recovery, bias, and precision. 


\subsection{Assessments}

Assessments are performed to gather results that can be evaluated to measure the effectiveness of the quality systems and processes implemented by the project. Assessments will be performed periodically during the year. The following types of assessments may be used at varying frequencies during the year:

- Management self assessment — an assessment performed by those immediately responsible for overseeing and/or performing the work to establish whether policies, practices, and procedures are adequate for assuring results needed.

- Management independent assessment - an assessment performed by an individual or group independent of the work performed to assure that policies, practices, and procedures are adequate for assuring results needed.

- Technical independent assessment - an assessment performed by an individual or group technically competent to do the work but independent of the work being performed to assure qualitative and quantitative aspects of the work are accomplished according to documented specifications.

Data quality assessments are conducted as project quality control checks. The focus of data quality assessments is independent verification of reported results. Data quality is routinely evaluated through technical review. If the complexity and/or significance of the work performed warrants it, the Project Manager will direct the QA representative and/or another staff member to conduct an additional quality assessment. The assessment is documented and retained in the project records. Documentation of the above assessments, as well as any external assessments performed, is maintained as project records. The Project Manager is responsible for ensuring that any deficiencies are corrected in a timely manner.

\subsection{Assessment Planning and Documentation}

Assessment planning is done by the project management team (including Project Manager, Task Leaders, Principal Investigator, and appropriate staff) in consultation with the project Quality Engineer. Assessments are in accordance with the SBMS subject area, "Assessment Management" (PNNL 2008a). The assessor plans the assessment on a Self-Assessment Planning Form (see example in Figure 9.1) where the scope of the assessment, topic, and supporting references are documented in the plan. A unique identification number is assigned to the plan and entered on an Assessment Log Sheet.

Results of assessments will be documented on a Self-Assessment Results form (see example in Figure 9.2). The corrective action and action owner will be documented on the assessment report. The Task Manager will assign the action owners, and the Project Manager will prioritize the corrective actions. An action item log will be maintained by the project Quality Engineer to track and close out actions, and to finally verify the corrective actions. The Project Manager will sign the assessment report when the corrective actions have been closed. The assessment plan and report will distributed to the appropriate Task Managers, Project Manager, and project records. 


\begin{tabular}{|l|l|}
\hline Scope \& Location: (General: Maintenance, Operations) & $\begin{array}{l}\text { I.D. Number: (ATS Number or other unique tracking } \\
\text { number) }\end{array}$ \\
\hline Topic: (Describe what will be assessed) & Date: (Date planning form is prepared) \\
\hline $\begin{array}{l}\text { References: (Cite source documents for performance expectations: i.e., Regulation, Environmental Permit, DOE Order, } \\
\text { A-Manual, Standards Based Management System [SBMS], Requirements, Procedures and Guidelines [RPG]). }\end{array}$ \\
\begin{tabular}{|l|}
\hline \multicolumn{1}{|c|}{ Performance Expectations } \\
Criteria developed from source documents that will be applied throughout the assessment. Each criteria/expectation will \\
RPG). Performance expectations should be limited to six maximum to allow the assessment to remain focused. Additional \\
planning forms can be completed to expand the scope of a particular assessment.
\end{tabular} \\
\hline $\mathbf{1 .}$ \\
\hline $\mathbf{2 .}$ \\
\hline $\mathbf{3 .}$ \\
\hline $\mathbf{4 .}$ \\
\hline $\mathbf{5 .}$ \\
\hline $\mathbf{6}$
\end{tabular}

Procedure: (Perform the following as applicable for the assessment)

Review assessment planning form

- Review applicable procedure/requirements. (references)

- Conduct performance tests and data validation.

- Observe the activity controlled by the procedure.

- Interview appropriate personnel about requirements and practices.

- Record observations based on comparison to plan.

- Document the results after receiving final information on the Self-Assessment Results form.

\section{Basics for the [ ] Planned [ ] Lessons Learned \\ Assessment: [] Responsive [ ] Other}

Work Package Number (optional):

\section{Assessment Requestor/Authorizing Person:}

\section{Assessor(s):}

Figure 9.1. Self-Assessment Planning Form 


\begin{tabular}{|l|l|}
\hline Assessor: & I.D. Number: \\
\hline Assessment Location: & Date: (Date assessment performed) \\
\hline
\end{tabular}

(Related to associated performance expectations)

(Use additional pages if necessary.) Concise and objective statements are the goal. Subjective comments may be added at the end and must be based upon a series of facts that support the comments. Include strengths and improvement opportunities. Include date the information is obtained and list of line managers or points-of-contact during assessment. Summary

1.

2.

3.

4.

5.

Subsequent Actions

(Related to associated results)

\begin{tabular}{|c|c|c|}
\hline Assigned Action & Action Owner & Due Date \\
\hline \multicolumn{3}{|l|}{1.} \\
\hline \multicolumn{3}{|l|}{2.} \\
\hline \multicolumn{3}{|l|}{3.} \\
\hline \multicolumn{3}{|l|}{4.} \\
\hline \multicolumn{2}{|l|}{ Actions Assigned By: } & Date: \\
\hline \multicolumn{3}{|c|}{ Completion (To be signed by Lead Assessor when assessment is completed.) } \\
\hline \multicolumn{3}{|l|}{ Signature: } \\
\hline \multicolumn{3}{|l|}{ Date: } \\
\hline \multicolumn{3}{|c|}{ Completion (To be signed by Manager when assessment is completed and all actions have been entered into ATS) } \\
\hline \multicolumn{3}{|l|}{ Signature: } \\
\hline Date: & & \\
\hline
\end{tabular}

Figure 9.2. Self-Assessment Results 


\subsection{Subcontractor Assessments}

If PNNL passes work on to subcontractors, periodic assessments of analytical subcontractors are performed as an oversight function or prior to contract award in accordance with the internal acquisition quality procedures. Provisions are made in the SOW for oversight assessment activities to be performed as necessary.

The results of all subcontractors' assessments (including surveillances and audits) will be made available to project and line management, individuals contacted, and the client as requested. The corrective action tracking, corrective action and closure response will be in accordance with the internal acquisition quality procedures. The official assessment report files and responses (audits and surveillances) are maintained in the PNNL Suppliers History File by the Quality Assurance Services group.

Periodic assessments of the well drilling and construction, drilling and sampling-related activities, and the Environmental Sciences Laboratory may also be performed in accordance with the requirements discussed above

\subsection{Preventive Equipment Maintenance}

Subcontracted organizations will be required to implement preventive maintenance on their equipment to mitigate the possibility of down time affecting cost and schedule. This will be specified in the SOW to the respective organizations.

\subsection{Specific Routine Procedures Used to Assess Data Precision, Accuracy, and Completeness}

The evaluation of laboratory precision, accuracy, and completeness is accomplished during the verification process performed upon receipt of data (see Section 7.0 of this plan).

\subsection{Corrective Action}

\subsection{Project Corrective Actions Resulting from Assessments}

As part of the continuous improvement processes initiated by the project management team, assessments will be tracked and improvement actions identified and prioritized. The Assessment Tracking System (ATS) is the process used by this master project for tracking and managing assessments, including determining Conditions and the development of actions. ATS supports the identification, control, and correction of items, services, and processes that do not meet established requirements. The SBMS subject area, "Assessment Management" (PNNL 2008a) documents this corrective action management process for handling and documenting events and assessments, including those that must be tracked in ATS such as formal project reviews or audits performed by the client or their representative; 
and management-initiated assessments. If immediate corrective action is required, the quality problem will be entered directly into the ATS and actions taken as specified in Section 12.2.

\subsection{Unplanned Deviations}

Corrective action must be initiated by the Project Manager or cognizant Task Leader when unplanned deviations from procedural, contractual, regulatory requirements, or construction specifications occur. These deviations will be documented by entering the quality problem information directly into the ATS in accordance with the SBMS subject area, "Assessment Management" (PNNL 2008a). The assessment must describe the problem, the cause of the deviation, the impact of the problem, and corrective action needed to remedy the immediate problem and to prevent recurrence.

Subcontractors will be required to have a system in place to identify, correct, and prevent recurrence of contractual, procedural or regulatory requirement(s) deviations, and to notify the PNNL point-ofcontact specified when such an event occurs. These requirements will be passed on in a SOW to the subcontractors.

\subsection{Planned Deviations}

Planned deviations from procedure, documented (including justification) and approved by the Project Manager or Task Leader in advance, do not constitute a deficiency and do not require generation of an assessment item. Documentation may consist of a hard copy e-mail or memo to the Project Manager or Task Leader. This documentation must include either an approval signature if on a memo or electronic approval via a reply to the e-mail indicating such approval.

\subsection{Measuring and Test Equipment Calibration Discrepancies}

Project staff must investigate instruments or equipment found to be operating outside acceptable operating ranges (as specified in the applicable technical procedure or manufacturer's instructions), and issues must be addressed in accordance with the SBMS subject area, "Assessment Management" (PNNL 2008a). When as-found data on an instrument's calibration report are found to be out of tolerance during the review and acceptance process of the contract, and supplier documents submitted in response to quality requirements, an "Out-of-Tolerance Notification" will be generated using the ATS in accordance with the SBMS subject area, Assessment Management (PNNL 2008a). Then the project staff must determine if there was any impact on data. When it is determined from calibration verification that Category 1 or 2 M\&TE is out of tolerance, proceed with the evaluation to determine impact on data and document the results with justification in the ATS.

Subcontractors will be required to maintain a system for identifying calibration discrepancies and tracing data or samples that may have been affected. Subcontractors will be required, via a SOW, to notify the PNNL point-of-contact as soon as possible when such an incident occurs. PNNL will perform periodic assessments to assess the effectiveness of subcontractor procedures and processes for calibration control. 


\subsection{Quality Assurance Reports to Management}

Quality activities such as project improvement efforts, significant deficiencies identified and the associated corrective actions, and summary of assessment results will be reported to the Project Manager. When major quality problems are identified, they shall be reported to the Project Manager. Surveillance plans and results of the surveillances are provided to the Project Manager and Task Manager after a surveillance event.

Quality-related problems identified by project personnel must be reported to project management immediately for resolution. Any problems involving data quality, sample integrity, or test measurements will be thoroughly documented and communicated to the appropriate Task Leader and Project Manager for resolution.

Significant quality-related problems that may affect customer satisfaction shall be communicated to the Product Line Manager by the Project Manager.

\subsection{Records}

\subsection{Records Control}

The SBMS definitions of project records and record material apply to this project. As stated in the SBMS subject areas, "Records Management" (PNNL 2008g), project records are any recorded information relating to a specific research project. Record material includes information, regardless of its media (e.g., hard copy, electronic, microfilm), created or received in connection with PNWD business or research activities that documents research and administrative functions, policies, decisions, procedures, operations, or other activities, and which is preserved for its value.

Note: E-mail that is record material must be printed out and maintained as the record copy unless the email is put directly into the PNNL Total Records Information Management (TRIM) System.

Record material that is not stored in field notebooks or laboratory records books (see Section 19.5 of this QAPjP) or is not electronic data gathered from sensors or instruments in the field and/or laboratory (see Section 14.3 of this QAPjP) such as project-specific field data forms, shall be scanned and managed as PDF files in accordance with Section 14.3. The record material shall be scanned and archived at least quarterly or more often, such as weekly or monthly, if the accumulation of the material is significant and inadvertent damage or loss would cause irreparable damage to the project.

Records that document the sampling subcontractor activities, analytical results, verification and compliance checks, quarterly and annual reports, test plans and associated results, groundwater monitoring plans, and assessment reports will be maintained as project records. Individual monitoring plans and work plans may identify other records requirements. Project records will be legible, identifiable, and maintained in accordance with the SBMS subject area, "Records Management" (PNNL 2008g). 
The Project Records Specialist prepares and submits a File Plan (See File Plan Form) for review and approval by the records management representative, project manager, and Quality Engineer. The Records Custodian reviews and updates the File Plan annually at a minimum, or when a major change to the program occurs. Records retention schedules are based on requirements in the Tri-Party Agreement (Ecology et al. 1989), which requires the retention of records for 10 years after termination of the Tri-Party Agreement.

\subsection{Records Transfer to Storage}

On an annual basis, the records custodian will transfer to storage inactive records as identified by project staff as not required for day-to-day operations. Sampling and analysis plans, assessments, and special project correspondences will be maintained by the project until the completion of the activity or project. The Project Records Specialist generates the internal form (e.g., Records Storage Form). The records management representative will sign the Records Storage Form as acknowledging receipt of the records and return a copy of this form to the Records Custodian. The Records Storage Form is then placed in project records.

Within 90 days of project completion or termination, records shall be transferred to storage and/or the client. The Project Records Specialist completes the appropriate internal form (e.g., Records Storage Form). The records management representative will sign the Records Storage Form as acknowledging receipt of the records and return a copy of this form to the Records Custodian. The Records Storage Form is then placed in project records.

\subsection{Electronic Data/Records Management}

Electronic data gathered from sensors or instruments in the field and/or the laboratory will be maintained and managed appropriately to allow for reproducible results. Electronic data that are directly delivered and/or used in analysis, i.e., delivered to the customer, will be maintained as project records in accordance with requirements in the SBMS subject area, "Records Management" (PNNL 2008g).

Electronic data produced by instrumentation or sensors are usually stored on that instrument and are only usable by the system itself. It is necessary for the electronic data to be transferred, without error, to a form that can be used by a variety of software applications. An example would be to transfer an ASCII file into a Microsoft Excel ${ }^{\circledR}$ file. ${ }^{1}$ To ensure the data-transfer process has occurred in an acceptable manner, a review of a representative sample, of sufficient data points to provide confidence that the data have been transferred properly, shall occur. The review method used and results obtained shall be documented and retained as project records in the LRB, in accordance with Section 19.5 of this plan. For retrieval of the data, the staff member shall record the use of the data on the media used to store the raw data and in the project records. The staff member shall ensure that unauthorized modifications are not made to the data during its use. The method of control shall be documented in the project records by the staff member. The staff member shall ensure that a backup of the data is maintained in the project records. The use of the data in software applications shall be documented, along with the software application name and version number.

\footnotetext{
${ }^{1}$ Microsoft Excel is a registered trademark of Microsoft Corporation.
} 
Electronic data shall be archived and saved as project records based on the project's record retention period. When the project records are required be maintained for a minimum of 10 years, after the close of the project, saving the raw electronic data files to a CD/DVD is sufficient. When the project's record retention requirements are longer than 10 years, the raw data files should be saved either to magnetic media (TRIM, tape) or optical media (CD, DVD). The TRIM system is one option for storing raw data files and is approved for projects that have a permanent retention period.

Backup and archive processes shall be followed for maintaining the data during the life of the project. Electronic data backups shall be performed nightly, in accordance with the requirements identified by the PNNL IT Computing Services - InfoSource website. The computer backup procedures in the PNNL InfoSource website for Data Backup Options shall be followed based on the type of computer or server on which the data are stored. The data backup process is identified in the following sections.

\subsubsection{Workstations}

PNNL staff members are responsible for ensuring data on their computers are regularly backed up. There are three options for backing up these data:

1. The staff member can sign up for one of the PNNL workstation backup and restore (WBR) services: WBR Connected DataProtector for Windows ${ }^{\circledR}$, WBR Mac for Macintosh ${ }^{\circledR}$, or WBR Networker for all other systems. ${ }^{1,2}$ WBR is free to each PNNL staff member for one workstation. Additional backup subscriptions are available for a small monthly fee. (See the WBR website for restore instructions.) The maximum backup size is 100 gigabytes (GB) for Windows workstations.

2. A network shared folder may be used to store files on a PNNL network file server. Network shared folders are backed up nightly. To retrieve files from a backup, request a file restore by calling the PNNL Help Desk at 375-6789 or send an e-mail. They will need the complete name of the shared folder (for example, $\backslash \backslash$ pnl10 \projects) and the name and date of the file or directory that needs to be restored.

3. Manually copy files to floppy disks, CDs, or DVDs. Most computers purchased through the Managed Hardware Program (MHP) come with large-capacity floppy drives, CD-RW drives, and/or DVD drives. A CD can hold 600 megabytes or more while DVDs can store $4.7 \mathrm{~GB}$. Either of these methods is suitable for backing up important data files, but not recommended for backing up the entire system.

\subsubsection{Servers}

The data backup options for servers include the following:

1. The Workstation Backup and Restore (WBR) service. For a small monthly fee, WBR performs a full backup of all the project's programs and data. (See the WBR website for restore instructions.)

2. Backing up to Zip disks or to a tape drive connected to the server. If a tape drive connected to the project server is used, refer to the manufacturer's instructions for establishing backup schedules and performing restores.

\footnotetext{
${ }^{1}$ Windows is a registered trademark of Microsoft Corporation.

${ }^{2}$ Macintosh is a registered trademark of Apple, Inc.
} 
Data archiving shall occur at least every two 2 weeks. It is recommended archiving occur at least once a week. The electronic data shall be archived to a CD/DVD and kept in the project working files until the electronic data are no longer being used; at that time, the electronic data shall be moved to TRIM when longer storage retention is required by records requirements.

\subsection{Procurement Control}

To ensure that procured items and services satisfy the technical and quality requirements of the user and/or client, all procurements shall be obtained in accordance with the applicable SBMS subject areas, "Procurement" (PNNL 2008c), "Purchase Orders/Subcontracts (PNNL 2008d)," "Purchasing Cards (PCards)" (PNNL 2008e), "Purchasing Through the Business-to-Business Program" (PNNL 2008f), and "Suspect/Counterfeit Items and Misrepresented Products, Reporting and Handling" (PNNL 2006d). In addition, electrical equipment purchased for use on the project shall also be obtained in accordance with the SBMS subject area, "Electrical Equipment: Designing, Purchasing, and Installing" (PNNL 2006c).

Quality-affecting materials (e.g., calibration standards, chemicals), equipment (e.g., instruments, geophysical measurement equipment), or services (e.g., calibration, analytical services, geophysical measurements, or other subcontracts for technical services) will be obtained in accordance with the SBMS subject area, "Purchase Orders/Subcontracts" (PNNL 2008d). For this project, the majority of procurements will result in purchases of services such as drilling, sampling, and analysis. All procurements will be obtained in accordance with the SBMS subject area, "Purchase Orders/ Subcontracts" (PNNL 2008d). SOWs for purchasing services shall be reviewed and signed by the project Quality Engineer to assure consistency of QA requirements specified to subcontractors with project quality standards in this QAPjP.

A QA representative shall approve all procurements containing QA requirements. Procurement documents shall specify technical and QA requirements, including documentation to be furnished by the supplier. Submittals from suppliers shall be reviewed to verify their compliance with the procurement document technical and QA requirements, in accordance with implementing procedure AQP-06, Review of Supplier/Subcontractor Submitted Documents. This review is performed by a QA representative.

Project staff members shall verify that items and services requested are acceptable when received in accordance with the above SBMS subject areas.

\subsection{Geophysical Equipment}

Procured instruments, components, and equipment (including rental equipment) used for geophysical work shall meet applicable standards such as those published by the Underwriter's Laboratory, American National Standards Institute, or the Institute of Electrical and Electronics Engineers, and whenever possible, should be listed by a nationally recognized testing laboratory. Upon arrival on site, all electrical equipment and instruments shall be inspected by a qualified electrical worker and staff with knowledge of the equipment. The equipment shall be powered for testing and the qualified electrical worker shall follow the appropriate diagnostics and testing procedure in the SBMS subject area, "Electrical Equipment: Designing, Purchasing, and Installing" (PNNL 2006c). Inspection results shall be 
documented on the Electrical Safety Design Criteria Checklist and forwarded to the PNNL Electrical Safety Engineer for approval prior to acceptance and use of the equipment in the field.

Note: The examination process and documentation described in the preceding paragraph is not required for minor components such as resistors, diodes, circuit boards, or similar electronic parts.

\subsection{Groundwater Sampling}

Test plans used for field experiments will include requirements for sample collection, sample handling, sample labeling, custody of the samples in the field to delivery to the laboratory or shipper, and water level measurements. The test plan procedure will pass on the requirements of the $E P A$ Requirements for Quality Assurance Project Plans (QA/R-5) (EPA/240/B-01/003) and HASQARD (DOE/RL-96-68). A review must be performed by the Quality Engineer during the planning stages and preparation of the test plan procedure.

\subsection{Groundwater and/or Sediment Analytical Measurements}

If the groundwater or sediment analysis will be conducted by subcontractors or collaborators on the project, requirements will be specified in the SOW or Letter of Instruction (LOI) as applicable, which shall be used to obtain the analytical services. The LOI is the mechanism to be used for work requests to other Hanford Site contractors. An LOI or SOW must also accompany each purchase order. A review must be performed by the Quality Engineer during the planning and preparation of the SOW/LOI. The SOW must define the data quality and any additional project requirements associated with the service requested. The data quality requirements should include a description of the QC samples for each analysis for determining the level of possible contamination from preparation and analysis. The project requirements should include information on analysis method, calibration standards traceable to the NIST, sample turnaround time and reporting requirements, and disposal requirements for remaining sample material and any process waste. The LOI/SOW will pass on the requirements of the EPA Requirements for Quality Assurance Project Plans (QA/R-5) (EPA/240/B-01/003) and HASQARD (DOE/RL-96-68) to the analyst.

\subsection{Other Hanford Site Contractor Services}

Other Hanford Site contractor services (e.g., well drilling and construction) will be obtained using the procurement process. An electronic requisition will be generated by project staff accompanied by a work authorization document (LOI or SOW). The work authorization document will describe the requirements for the requested services. The SOW/LOI will pass on the requirements of the EPA Requirements for Quality Assurance Project Plans (QA/R-5) (EPA/240/B-01/003) and HASQARD (DOE/RL-96-68) to the subcontractor. A review must be performed by the Quality Engineer during the planning stages and preparation of the SOW or LOI.

\subsection{Technical Services from Subcontractors}

Technical services from subcontractors will be procured by using a work authorization document (LOI or SOW) accompanied by a work package authorization (WPA) or work orders. A review must be 
performed by the Quality Engineer during the planning stages and preparation of the SOW/LOI. The work authorization document must define the data quality and any additional project requirements associated with the service requested. The data quality requirements should include a description of the QC samples for each analysis for determining the level of possible contamination from preparation and analysis. The project requirements should include information on analysis method, calibration standards traceable to the NIST, sample turnaround time and reporting requirements, and disposal requirements for remaining sample material and process waste. The SOW will pass on the requirements of the $E P A$ Requirements for Quality Assurance Project Plans (QA/R-5) (EPA/240/B-01/003) and HASQARD (DOE/RL-96-68) to the subcontractor. Where software is involved, DOE Order 414.1C requirements will be passed on to the subcontractor.

\subsection{Staff Training}

Staff performing activities affecting quality shall be issued documented training assignments, including applicable project administrative and technical procedures and this plan.

1. Task Leaders and staff members will assess project-specific training needs. The assessment will include evaluating cumulative training records of the staff.

2. Task Leaders will assign reading and/or briefings of procedures as needed. If training is assessed and the need for formalized training is identified, the staff member will be scheduled to attend a formal training class.

3. Task Leaders and staff will document training on a Briefing Document, an individual on-the-job training (OJT) form, a Reading Assignment Documentation form, or a Group OJT or Reading Assignment Documentation form. These forms are available internally to PNNL staff.

Documentation shall be sent to the PNNL Laboratory Training Coordinator for input into the training database. The training database will contain the record copy of project staff training.

Subcontractors are responsible for special training of its staff in accordance with the respective SOW.

The Columbia River Project shall utilize personnel who are knowledgeable and possess adequate technical, managerial, or professional skills to perform all their assigned tasks. The Project Manager will identify any additional specific project-related processes that will require the project staff training and qualification, and who will be responsible for assuring the project-specific training will be developed, delivered, and changes managed in accordance with the SBMS subject area, "Training Design, Development, Implementation and Evaluation" (PNNL 2002). The project shall maintain training documentation for project-required coursework or OJT taken by staff that is not capable of being tracked in the Laboratory's training database in accordance with the SBMS subject area, "Training and Qualification for Staff and Non-Staff' (PNNL 2005b).

The Project Manager or his/her delegate, shall inform the immediate manager of project staff of his/her requirement to take project-required training and assure that the training has been completed prior to project staff conducting work that requires the training. The immediate manager of project staff, or delegate, shall record the need for identified project-required training and assuring training (and retraining for changes) records (for both Lab-level and project -specific training) will be maintained in accordance with the SBMS subject area, "Training and Qualification for Staff and Non-Staff" (PNNL 2005b). 
The development of software products that require complex or unfamiliar interactions with users and operators should include a comprehensive plan for training. The training plan should include the following:

a. A description of the populations to be trained, the training objectives for each population, and the content to be covered in the training

b. An estimate of the amount of resources necessary for training development, delivery, and time expenditures

c. Procedures for evaluating the effectiveness of the training and for making modifications to the training.

The Project Manager has identified the following project-specific training requirements on which the project core team members will have been briefed:

- The Project Management Plan (PMP)

- QAPjP

- Health and Safety Plan

The individual projects shall maintain training documentation for project-required coursework, or OJT training taken by staff, which is not capable of being tracked in the Laboratory's training database in accordance with the SBMS subject area, "Training and Qualification for Staff and Non-Staff"

(PNNL 2005b).

\subsection{Software Control}

Various tasks of the project require the use of databases and software, which are managed, controlled, and operated by entities outside PNNL. The project also requires the use of databases and software that are developed, managed, controlled, and operated by PNNL. A graded approach is used to establish software QA requirements based on identified risk. Software QA at PNNL is based on DOE Order 414.1C, Quality Assurance, which establishes specific requirements for software related to safety and nuclear facilities.

The project uses databases, custom applications, and configurable software to support various activities. These databases, custom applications, and configurable software (spreadsheets, and queries) used to generate reportable results shall be documented in accordance with the SBMS subject area, Software (PNNL 2007d). This documentation is maintained in project files.

\subsection{Safety Software and Software Applications}

"Software" is defined as computer programs, including computer programs embedded in firmware (see the SBMS subject areas, "Safety Software" [PNNL 2008i] or "Software" [PNNL 2007d]). Software that is an integral part of firmware or equipment, where all software maintenance is performed by the vendor, and the software is verified as an integral part of the system (e.g., calibration with known standard materials) is excluded. Any vendor will be required to follow the NQA-1-2000 standards for software when the software that is part of firmware is identified as safety software. The safety software 
clause (QA-197a) will be passed down in any SOWs, at a minimum, and possibly with additional clarification, when requested by the vendor and the software being used or developed has been identified as safety software. The software clause (QA-197b) will be passed down in any SOWs, at a minimum, and possibly with additional clarification, when requested by the vendor for non-safety applications being developed.

All software applications used for project work under this plan will be reviewed and identified as safety software or software. The grading process for safety software will be recorded and copies for each application will be maintained as project records for each project that falls under this plan. Software applications that will follow this plan have the potential to be identified as safety software and when graded as such, will follow the "Safety Software" (PNNL 2008i) Level C requirements at a minimum as identified in SBMS. The SBMS subject area, "Safety Software" (PNNL 2008i) is based on DOE Order 414.1C, which includes the NQA-1-2000 standard.

If applications are not identified as safety software, they will be documented as software and the documentation will be maintained as project records for each project. Safety software and software applications identified for the projects in this plan will perform the work activities identified below that pertain to custom developed, configurable, acquired/legacy, utility calculations, and commercial design and analysis software.

All safety software applications are required to be identified in the Information Resource Inventory (IRI). All safety software will be identified as safety system software, safety and hazard analysis software and design software, or safety management and administrative controls software. The following will also be identified for each software application in the IRI: type of software, graded level, version of the software and the scope of the software, for the intended use with the project. The owner and point of contact information will also be identified in the IRI.

\subsubsection{Minimum Documentation Requirements}

To ensure that the implementation of the software satisfies requirements, the following documentation is required as a minimum for all safety software applications. These document requirements must be reviewed and processed through ERICA for software code being developed as a deliverable. The rigor of the documentation will be decided based on the grading of the safety software application. Refer to the SQA Activity Tailoring exhibit, in the SBMS subject area, "Safety Software" (PNNL 2008i), for guidance on the rigor needed for the documentation requirements. The document requirements will be for each document identified below. The document requirements may be grouped together in one document or may be separated into separate documents identified below:

a. Software Requirements Specifications (SRS)

b. Software Design Description (SDD)

c. Verification and Validation Plan (VVP)

d. Verification and Validation Report (VVR)

e. Configuration Management Plan (CMP)

1. A problem reporting and corrective action tracking system will be identified with the CMP documentation. 
2. Data management process will also be identified, when applicable.

f. Procurement contractual documentation, when applicable.

\subsubsection{Software Requirements Specification}

The Software Requirements Specification (SRS) shall clearly and precisely describe each of the essential requirements (functions, performances, design constraints, and attributes) of the software and the external interfaces. Each requirement shall be defined such that its achievement is capable of being objectively verified and validated by a prescribed method (e.g., inspection, analysis, demonstration, or test).

The SRS is subject to the Software Requirements Review (SRR), identified in applicable configuration management plans when needed, which identifies the QA aspects of work activities.

\subsubsection{Software Design Description}

The Software Design Description (SDD) shall depict how the software will be structured to satisfy the requirements in the SRS. The design document shall describe the components and subcomponents of the software design, including databases and internal interfaces, and provide a technical description of how the software will meet the requirements established in the requirements specification. Its most important function is to describe a decomposition of the whole system into components (subsystems, segments, etc.) that are complete and well bounded. In addition, it should document the rationale for the more important design decisions to facilitate the understanding of the system structure.

The SDD will document major system features such as databases, diagnostics, external and internal interfaces, as well as the overall structure of the design. It involves descriptions of the operating environment, timing, system throughput, tables, sizing, centralized or distributed processing, extent of parallelism, client/server, reusable objects library, program design language (PDL), prototypes, modeling, simulation, etc. The design description will also document any input and output data that may be required. The QA organizational element can observe demonstrations, which is a more efficient way to review and assess written design documentation.

The SDD will be updated after each significant review. A new version containing a more detailed design description is developed for each subsequent review.

\subsubsection{Verification and Validation Plan}

The Verification and Validation Plan (VVP) shall identify and describe the methods (e.g., inspection, analysis, demonstration, or test) to be used:

1. To verify the following:

- Requirements in the SRS have been approved by staff with appropriate authority

- Requirements in the requirements specifications are implemented as described in the SDD

- Design documented in the SDD is implemented in the code. 
2. To validate that the code, when executed, complies with the requirements expressed in the requirements specification.

The VVP describes the overall approach for verification and validation of the software or modeling approach and will be produced and reviewed incrementally, for safety software applications. The tasks, methods, and criteria for verification and validation will be described in the appropriate VVPs for each application.

The VVP will be used for documentation of the testing standards and practices as they are defined in the plan for each application. The VVP will document the scope of the validation testing to ensure the baseline requirements, and describe the stages of development that require customer review and the extent of the verification that will precede such a review.

The VVP will specify minimum test documentation requirements for each test performed. Additionally, a section of each plan will identify a verification matrix where the requirements are listed with their corresponding test. A matrix will be maintained during the life of the software and will be used to verify all the requirements have been met, identified, and tested.

The contents of the VVP will be evaluated at a Verification and Validation Plan Review (VVPR) prior to testing. Such a review will be conducted when significant changes are made to the baseline. The VVPR will be used to identify all changes to be tested and to pass on pertinent information to the appropriate testing staff.

\subsubsection{Verification and Validation Report}

The Verification and Validation Report (VVR) shall describe the results of the execution of the VVPR. The report summarizes the observed status of the software as a result of the execution of the VVP. The report should include the following information:

a. Summary of all life-cycle verification and validation tasks.

b. Summary of task results.

c. Summary of anomalies and resolutions.

d. Assessment of overall software quality.

e. Summary from the verification matrix.

f. Recommendations such as whether the software is, or is not, ready for operational use.

The report may be a full report or a summary (depending upon the grading of the software).

\subsubsection{User Documentation}

User documentation will be developed for applications where the code is part of the deliverable. 


\subsubsection{Configuration Management Plan}

The Configuration Management Plan (CMP) shall document methods to be used for identifying software items, controlling and implementing changes, and recording and reporting change implementation status. The CMP should describe the tasks, methodology, and tools required to assure that adequate configuration management procedures and controls are documented and being correctly implemented. If the CMP is not a stand-alone document, and is included in the QAPjP or PMP, it is not necessary that the QA organizational element prepare it; however, it is essential that one exist for each project or set of applications under each project.

The CMP should describe the methods to be used for the following:

a. Identifying all configuration items (each software item will be identified if it is considered to be safety software or not; if identified as safety software, the level will be identified as well)

b. Controlling and implementing changes.

c. Recording and reporting change and problem reports implementation status.

d. Conducting configuration audits.

e. Identifying review and approval cycle as well as signature authority.

f. Identifying personnel responsible for maintaining the baselines and distributing the plan.

The CMP shall contain the information identified in the SBMS subject area, "Safety Software" (PNNL 2008i) for the appropriate level of software to which the application was graded. Most software application for the work under this project will be graded at Level C.

\subsection{Support Software}

Support software is software that is not incorporated directly into the safety software product, but is used to support development, operation, and/or maintenance during the software life cycle and directly affects the performance of the software product. Support software includes both software tools and system software.

Support software can be critical to the successful deployment, operation, or maintenance of a software product. Based on the impact of the given support software on the product, the software engineering activities and documentation will be planned for and applied. (See the SBMS subject area, "Safety Software" [PNNL 2008i] Exhibit: Support Software Grading and Tailoring.) Support software is classified as either a software tool or system software.

A software tool is defined as a computer program used in the development, testing, analysis, or maintenance of a program. More specifically, tools are software with a direct impact on performance, such as tools that generate code or build source code into executables, tools that execute requirementsverification test cases generating test data or results. Tools that have no direct impact on performance are excluded, such as text editors (non-compiling), TRIM, configuration management software (e.g., Subversion $^{\circledR}$, PVCS $^{\circledR}$, Concurrent Version System [CVS], SourceSafe ${ }^{\circledR}$ ), diagramming and document 
creation tools, MS Project $^{\circledR}$, etc. ${ }^{1,2,3,4,5}$ Performance for the purposes of the above definition depends on the specific product type. In the example of a process controller, speed and accuracy may be part of its performance. Correctness is also part of performance. Consequently failure of automated verification software to identify a defect in the product is an impact on requirements performance.

System software is software that is designed to enable the operation and maintenance of a computer system and its associated computer programs. An example of system software is the operating system that the application runs on.

The following steps shall be followed, at a minimum, to document support software that will be used to support the safety software applications. Additional clarification and support can be obtained from the project Quality Engineer and the PNNL Software Quality Assurance Subject Matter Expert.

1. At the project planning phase, identify and document the support software that will be used on the project, and classify it as either a software tool or system software. A list of examples is provided in the SBMS subject area, "Safety Software" (PNNL 2008i) Exhibit: Examples of Support Software. If any of the support software is currently listed in the DOE Safety Software Central Registry, this may reduce the need for additional activity or documentation.

2. From the list of support software generated in step 1, determine and document how each piece of software will be evaluated, reviewed, tested, and accepted for use. Evaluate the impact of support software changes on the software product to determine the level of review and testing that will be required. See the SBMS subject area, "Safety Software" (PNNL 2008i) Exhibit: Support Software Grading and Tailoring.

3. From the list of support software generated in step 1, determine and document the level of configuration control that will be applied to each piece of software. Software tools must be placed under configuration control. All system software that affects the performance of the product must be placed under configuration control.

4. In terms of testing, the extent of system software evaluation/testing should be documented along with justifications for the planned approach.

5. Software tools that affect the performance of the software must be evaluated, reviewed, tested, and accepted for use.

\subsection{Software Use in Analysis}

The use of software of any kind to conduct analyses delivered, or in support of a deliverable to the customer, includes data analysis tools, such as spreadsheets and statistical analysis software, databases, modeling and simulation tools. Excluded are software productivity tools such as word processors and spreadsheets when no automated calculations, macros, or scripts are used. Staff working on projects under this plan shall work in accordance with requirements for the control of software used in analyses as

\footnotetext{
${ }^{1}$ Subversion is a registered trademark of CollabNet Inc.

${ }^{2} \mathrm{PVCS}$ is a registered trademark of the Serena Software Company.

${ }^{3} \mathrm{CVS}$ is freeware available from GNU.org.

${ }^{4}$ SourceSafe is a registered trademark of the Microsoft Corporation.

${ }^{5} \mathrm{MS}$ Project is a registered trademark of the Microsoft Corporation.
} 
defined in the SBMS subject area, "Safety Software" (PNNL 2008i) or "Software" (PNNL 2007d) based on how the software being used is graded.

\subsection{Utility Calculations}

The purpose of this section is to define a uniform method for documenting the quality controls in place when using software packages (e.g., Excel, Mathematica ${ }^{\circledR}$, Matlab $^{\circledR}$, Mathcad ${ }^{\circledR}$, etc. known as Utility Calculations) for calculations that are a significant part of a client deliverable, but not classified as safety software. ${ }^{1,2,3}$ As stated above, the safety software classification involves software failure that could result in the loss of life or serious injury, exposure to hazardous materials in excess of standards, serious damage to the environment, or noncompliance with laws or regulations.

Excel or other utility calculation analyses that are not used for a significant part of a client deliverable, or are only used as a double check are exempt from these instructions. These instructions apply to the use of scripts and/or macros, within Excel, as well as Excel basic calculations. Portions of this project that have been identified as containing safety software must follow the SBMS subject area, "Exhibit: Utility Calculation Guidance" identified in "Safety Software" (PNNL 2008i). For additional information, refer to the SBMS "Software" (PNNL 2007d) subject area, "Section 11: Using Software to Conduct Analysis."

NOTE: Excel is used as the example in these instructions; however, the process is the same for all other utility calculations.

These requirements and instructions apply to Project Managers and staff who will use Excel to conduct analysis to be delivered to the client, or to conduct analyses in support of a deliverable to the client. The process shall be implemented as follows:

- Requirements and Risk Identification: Plan out the analysis that will be performed and assess the risk associated with the failure of the software. Document the associated risk and the analysis to be performed (this could be one paragraph in a Microsoft Word $\AA$ document or on another tab in the Excel spreadsheet itself).4 (See risk examples in Table 17.1.)

- Design and Validation Planning: Prepare and document how the Excel file will be validated/ reviewed and tested by an independent technical reviewer. Identify and document who will perform the independent technical review. (Identify what the problem is that is trying to be solved and what actual calculations are being performed to solve the problem. This information will be useful for the independent technical reviewer. This could be one paragraph in a Word document or on another tab in the Excel spreadsheet itself.)

\footnotetext{
${ }^{1}$ Mathematica is a registered trademark of Wolfram Research, Inc.

${ }^{2}$ Mathcad is a registered trademark of Parametric Technology Corporation

${ }^{3}$ Matlab is a registered trademark of The MathWorks, Inc.

${ }^{4}$ Microsoft Word is a registered trademark of the Microsoft Corporation.
} 
Table 17.1. Software Risk Management Examples

\begin{tabular}{|c|c|c|c|c|c|}
\hline Identified Risk & $\begin{array}{l}\text { Overall } \\
\text { Risk } \\
\text { to Project }\end{array}$ & Preventive Action & $\begin{array}{c}\text { Contingency } \\
\text { Action }\end{array}$ & Trigger & Owner \\
\hline $\begin{array}{l}\text { Changing } \\
\text { requirements } \\
\text { after starting } \\
\text { design// } \\
\text { development. }\end{array}$ & Medium & $\begin{array}{l}\text { Customer approval of } \\
\text { requirements before } \\
\text { design/ development, } \\
\text { flexible design and CM } \\
\text { process. }\end{array}$ & $\begin{array}{l}\text { Changes affect } \\
\text { either schedule } \\
\text { or resource } \\
\text { allocation. }\end{array}$ & $\begin{array}{l}\text { Customer } \\
\text { request. }\end{array}$ & $\begin{array}{l}\text { Battelle/ } \\
\text { Customer }\end{array}$ \\
\hline $\begin{array}{l}\text { Incomplete input } \\
\text { data. }\end{array}$ & High & $\begin{array}{l}\text { Identify appropriate } \\
\text { sources of validation data. }\end{array}$ & $\begin{array}{l}\text { Manual updates } \\
\text { to input tables } \\
\text { are tracked } \\
\text { through the } \\
\text { change control } \\
\text { process. }\end{array}$ & $\begin{array}{l}\text { Appropriate } \\
\text { input tables not } \\
\text { available. }\end{array}$ & $\begin{array}{l}\text { Battelle/ } \\
\text { Customer }\end{array}$ \\
\hline Identified Risk & $\begin{array}{l}\text { Overall Risk } \\
\text { to Project }\end{array}$ & Preventive Action & $\begin{array}{l}\text { Contingency } \\
\text { Action }\end{array}$ & Trigger & Owner \\
\hline $\begin{array}{l}\text { Change in project } \\
\text { budget or/or } \\
\text { schedule. }\end{array}$ & Low & $\begin{array}{l}\text { Define and implement new } \\
\text { process. }\end{array}$ & $\begin{array}{l}\text { Continue current } \\
\text { process. }\end{array}$ & $\begin{array}{l}\text { Coordination } \\
\text { issues with } \\
\text { customer. }\end{array}$ & $\begin{array}{l}\text { Battelle/ } \\
\text { Customer }\end{array}$ \\
\hline $\begin{array}{l}\text { Invalid regulatory } \\
\text { products that rely } \\
\text { on calculations } \\
\text { performed with } \\
\text { this software. }\end{array}$ & Low & $\begin{array}{l}\text { Development and } \\
\text { execution of a Software } \\
\text { Test Plan to cover all } \\
\text { calculations in the system. }\end{array}$ & $\begin{array}{l}\text { Identify critical } \\
\text { calculations and } \\
\text { test based on use } \\
\text { of the system. }\end{array}$ & $\begin{array}{l}\text { Software codes } \\
\text { are required to } \\
\text { be reviewed } \\
\text { with a customer } \\
\text { QA/QC } \\
\text { process. }\end{array}$ & Customer \\
\hline
\end{tabular}

Overall risk rating is medium.

- Implementation: Conduct the analysis using the Excel spreadsheet with the appropriate calculations based on the planning previously performed. (If the implementation of the analysis has changed, go back and update the risk associated with the analysis and the documentation to be used for the validation, if applicable).

- Verification: Review/verify the results of the analysis. Review the results produced from the analysis. Determine if the analysis and results support the problem that is trying to be solved. Document the verification/review step. (Documenting this step can be done with one paragraph, in a Word document or on another tab in the Excel spreadsheet itself, of what was reviewed and identify if the outcome was acceptable, or if additional work needs to be done.)

- Validation: Conduct independent reviews of results and validation. Provide the identified independent technical reviewer the Excel spreadsheet and Word document, if applicable. (The reviewer needs to have all the information regarding the requirements, risk, design, and review expectations to perform the review.)

- Independent Technical Review: Reviewer performs the review, per the instructions provided, and documents any additional checks performed on the file that extended outside the original scope of the review and the method used to perform the review of the results. The reviewer documents the outcome of the review. (The documentation can be one paragraph in a Word document or on another tab in the Excel spreadsheet itself.) 
- The results shall be determined based on using an alternate method to perform the analysis. Typical alternate methods include literature review, empirical data, hand-calculations, or executing the analysis on a comparable but different tool.

- Documentation: Print the Excel spreadsheet with the analysis/results and attach the Word document or the tab in the Excel spreadsheet itself that contains the identified requirements, risk, design, validation steps, verification, and independent technical review steps and results. Have the independent technical reviewer sign the document. The verifier needs to sign the verification step. Place this signed document in project records.

\subsection{Nonconformances and Deficiencies}

For procured materials found to be in nonconformance with specifications or where the quality of an activity is found not to be in compliance, the quality problem will be documented in the ATS in accordance with the SBMS subject area, "Assessment Management" (PNNL 2008a). Corrective actions are documented in ATS in accordance with the SBMS subject area, "Assessment Management" (PNNL 2008a).

If a deficiency is found where a procedure or process is not followed or the activity is not in compliance with a procedure or process, the deficiency will be documented into the ATS in accordance with the SBMS subject area, "Assessment Management" (PNNL 2008a). Corrective actions will be documented using ATS in accordance with the SBMS subject area, "Assessment Management" (PNNL 2008a).

Subcontractors will be required to have a system to identify and disposition nonconforming items, procedure deficiencies, processes not followed, or activities not in compliance to a procedure or a process. This requirement will be specified in a SOW.

\subsection{Document Control}

\subsection{Quality Assurance Project Plan Control}

Distribution and control of this QAPjP shall be performed in accordance with the SBMS subject area, "Publishing Scientific and Technical Information" (PNNL 2007b). Modifications to this plan shall be made either by revision or by issuing an Interim Change Notice (ICN). (See Figure 19.1 for the ICN form and instructions.) This plan will be revised to the next revision number after four ICNs or a major change in project scope or requirements. Any PNNL staff member may request a change to this QAPjP by submitting the requested change in writing to the Project Manager and Quality Engineer. All reviewers listed on the signature page and affected by the change will approve the revision. The ICN will be placed in front of the signature page and the individual pages will be placed, or the necessary correction will be lined out and corrections added with the appropriate initials and date. The QAPjP will be reviewed at least every 2 years. 
HEADER:

\section{INSTRUCTIONS FOR ICN FORM}

The ICN number is identified as ICN No.-

For a published document, each page of the ICN shall have a header on the right upper corner that includes the report number, the date and the pagination. The number of the ICN must be placed after the PNNL number. The second line of the header should show the date and pagination. The cover sheet needs to identify how many pages in the ICN packet.

Example header: PNNL-xxxxx-ICN-x

Month, day, year; Page $\mathrm{x}$ of $\mathrm{xx}$

\section{SECTION A.}

Self-explanatory.

\section{SECTION B.}

Include all actions that the document holder must take to update the procedure or instruction. Possible actions include: replacing pages of the document with pages that are distributed with the ICN and marking up the document (in ink) to reflect the changes identified on the ICN or attach the ICN cover sheet to the front of the document.

For a "Published" groundwater monitoring plan include the following statement: "Attach this ICN to the front of the document, just before the title page."

\section{SECTION C.}

Identify, by title, all personnel whose job functions will be affected by the change and include a brief description of the effect. If there is no effect on personnel (e.g., the change was made to clarify the intent of the procedure or to correct a typographical error) this block should be marked "N/A."

\section{SECTION D.}

State the reason for the change followed by a description of the change (including the affected paragraph, information which is deleted, and the actual wording of any replacement test) for each change included on the ICN.

\section{SECTION E.}

The Cognizant Manager shall document the reason for not obtaining original reviewers approval and/or any other decisions that must be documented. Additionally, list the individuals who will receive the document (distribution list).

\section{SECTION F.}

Identify type of change and document required approvals.

Figure 19.1. Interim Change Notice 
Page of

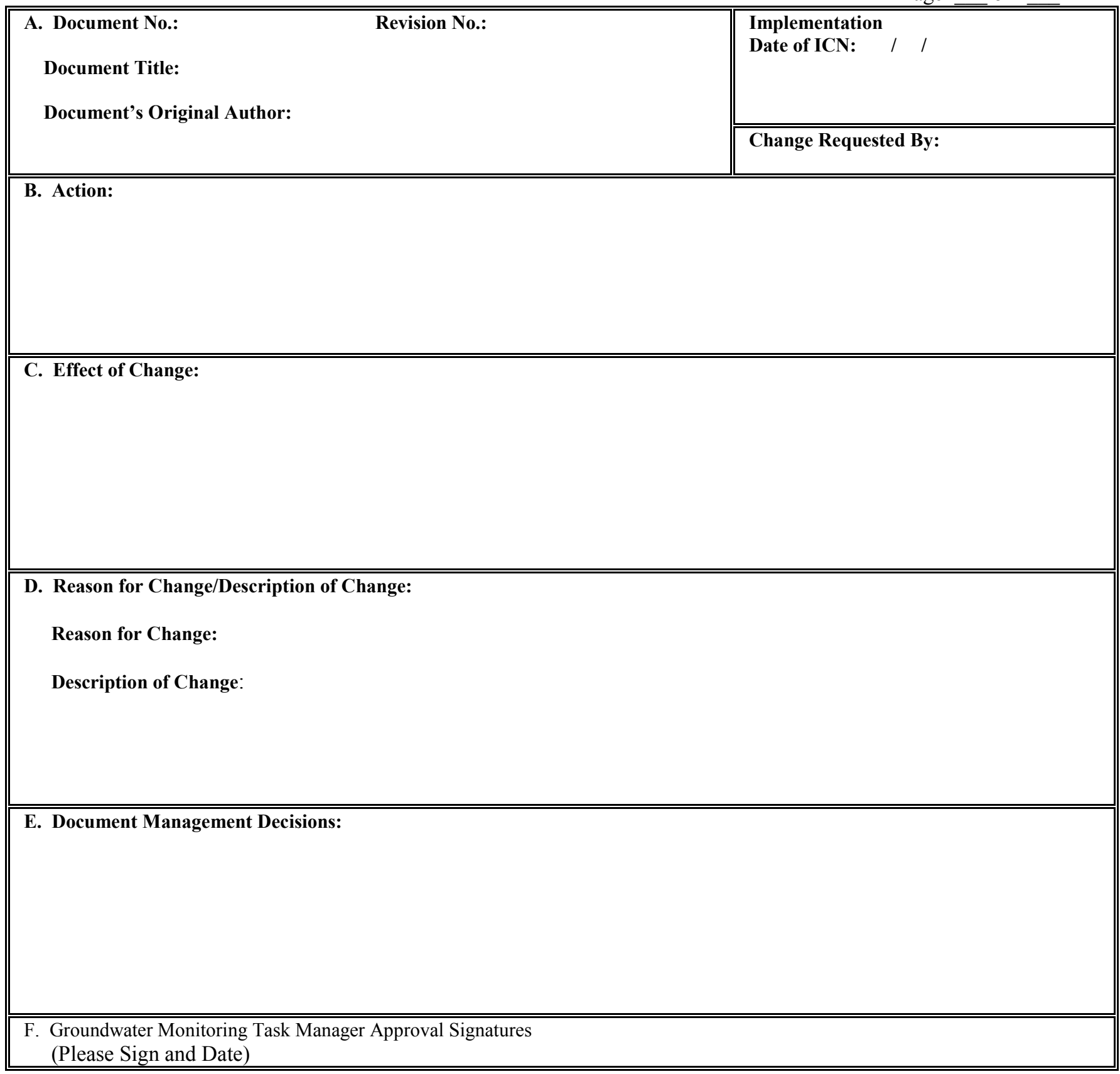

Project Quality Engineer Approval:

Date:

Author Approval:

Date:

Other Approvals:

Date:

Figure 19.1. (contd) 


\subsection{Technical Procedure Control}

Technical procedures referenced by this QAPjP and used by PNNL staff will be contained in a PNNL internal procedure manual, Procedures for Ground-Water Investigations (PNL-MA-567) or other procedure manual as appropriate. Technical procedures will be distributed and controlled in accordance with the SBMS subject area, "Document Control" (PNNL 2006b). Modifications to any of the internal procedures shall be made either by revision or by issuance of an ICN.

Procedures will be revised after two major ICNs or if the procedure format has changed. Any PNNL staff member may request a change to procedures at any time by submitting the requested change in writing to the author. The author, technical reviewer, Task Manager, and project Quality Engineer will review and approve the ICN. The ICN will be placed in front of the signature page and the individual pages will be placed or the necessary correction will be lined out and corrections added with initial and date. Contact the Project Quality Engineer for the electronic copy of the ICN. New or revised technical procedures whether they will be included in the internal procedures manual or not, must be developed in accordance with SBMS subject area, "Procedures, Permits, and Other Work Instructions" (PNNL 2004). The procedure owner is required to review the procedure at least every 2 years.

\subsection{Administrative Procedure/Instruction Preparation and Control}

Administrative procedures/instructions used by PNNL staff will be developed, approved, and controlled to ensure consistent application by those staff performing the defined task(s). These procedures/instructions will be developed, approved, and controlled in a manner that has been approved by the Project Manager and Quality Engineer.

\subsection{Test Plans and Other Work Documents}

Test Plans and other work instructions used by PNNL staff will be developed, approved, and controlled to ensure consistent application by those staff performing the defined task(s). These procedures/instructions will be developed, approved, and controlled in a manner that has been approved by the Project Manager and Quality Engineer.

Distribution and control of test plans and other plans shall be performed in accordance with the SBMS subject area, "Publishing Scientific and Technical Information" (PNNL 2007b).

\subsection{CERCLA Sampling and Analysis Plans}

Monitoring plans supporting CERCLA groundwater operable units are referred to specifically as SAPs and are released as DOE documents. Distribution and control of these plans shall be performed in accordance with the SBMS subject area, "Publishing Scientific and Technical Information" (PNNL 2007b). The SAPs are reviewed and, if necessary, revised annually; this requires DOE and regulatory agency review and approval. The SAPs may have temporary (periods less than 1 year) additions (adding constituents, wells, or increasing frequency), or unavoidable changes (such as dry wells, missed or delayed samples); these require notification to project management and DOE, as well as notification to the regulatory agency via e-mail messages or Unit Manager Meeting minutes. 
Permanent changes (for periods more than 1 year) are identified to DOE and regulatory agencies for approval prior to documenting them in the revised SAPs. Distribution and control of the revised SAPs shall be by the project editor.

Project change control in the interim period between SAP revisions is maintained by issuance of an ICN in accordance with the process described in the SBMS subject area, "Document Control" (PNNL 2006b). These changes are approved by project management, attached to the current plan in the project records, and implemented via the project scheduling system.

Waste Control Plans and Waste Management Plans also support CERCLA groundwater operable unit activities, and are released as DOE documents. These plans may be revised as needed, based on changes in the activities occurring within the respective operable unit. These plans may have changes made to the well tables (e.g., new wells) that are documented by submitting the revised page(s) to the Unit Manager Meeting minutes. These page revisions are placed with the original plan in the associated operable unit File Record category of the project records.

\subsection{Field Notebooks and Laboratory Record Books}

Field notebooks and LRBs used by the Columbia River Project staff will be managed, controlled, and reviewed in accordance with the SBMS subject area, "Laboratory Record Books" (PNNL 2000).

The PM shall ensure that all field notebooks and LRBs are reviewed at least twice per year. The reviewer, a qualified individual, confirms there is sufficient detail to trace the investigation and confirm the test results or repeat the investigation and achieve comparable results, without recourse to the original investigator.

Non-PNNL project staff, such as subcontractors and/or collaborators shall comply with the following procedural steps regarding laboratory records books, or a project-approved equivalent:

1. Use LRBs with beige-colored binding.

2. The initial LRB custodian shall complete the title, author, and period covered sections of the information block (first sheet inside the cover). If the LRB is transferred, the new custodian shall enter their name, payroll number, location, and date received to the lower portion of the information block.

3. If persons other than the custodian make entries, the custodian shall list above or below the information block on the first sheet inside the cover, the names of those persons and obtain sample signature and initials from each.

4. Use the following procedure as new project number and project or activities are initiated.

- Record the starting page, the project or activity title in the table of contents.

- Record as the first entry the research activity title, the project or work authorization number, and a brief description of the objectives and planned approach.

- Record observations/data chronologically. Describe (narrative or sketch) experimental apparatus, equipment, and any procedures, data sheets, etc., that are used.

5. Date and sign each page. List person(s) who performed the work.

6. Record information only in permanent ink, line out unused portions of pages, and keep pages intact. 
7. Do not erase or obliterate entries. Mark out errors or corrections with single lines. Initial and date all changes other than editorial corrections. If the change is substantive, record the reason for it.

8. Use the following steps if it is necessary to attach a loose sheet.

a. Attach the sheet to an unused page of the LRB by tape or glue.

b. Write the LRB and page numbers on the attached sheet (in case it comes loose).

c. Make an entry in the LRB to introduce or describe the attached sheet.

9. Maintain a list in the project or activity file identifying the LRB numbers, custodians, and locations.

10. Record as the last entry for a project or activity a statement noting completion of the work or, if appropriate, reference to a subsequent LRB.

11. Store LRBs in metal file cabinets or receptacles that prevent physical damage or access by unauthorized persons when not in use, and allow easy retrieval for periodic inventory.

12. Notify Document Control in writing when LRBs are reassigned.

13. Return LRBs to Document Control when complete or at project end. Users may copy appropriate pages for their personal files and future reference. If the staff member for future reference retains the LRBs, they must be protected from physical damage or access by unauthorized persons and made available for periodic inventory.

14. Return LRBs to Document Control or request reassignment when the custodian terminates employment.

15. Make copies of LRBs, or applicable pages, for inclusion in project files, when appropriate.

\subsection{References}

10 CFR 830, Subpart A- “Quality Assurance Requirements.” U.S. Code of Federal Regulations.

40 CFR 136, Chapter 1, Appendix B (7/1/01). U.S. Environmental Protection Agency. "Guidelines Establishing Test Procedures for the Analysis of Pollutants." U.S. Code of Federal Regulations.

40 CFR 264. "Standards for Owners and Operators of Hazardous Waste Treatment, Storage, and Disposal Facilities." U.S. Code of Federal Regulations.

40 CFR 265. "Interim Status Standards for Owners and Operators of Hazardous Waste Treatment, Storage, and Disposal Facilities." U.S. Code of Federal Regulations.

Atomic Energy Act. 1954, as amended, Ch. 1073, 68 Stat. 919, 42 USC 2011 et seq.

CAWSRP - Conducting Analytical Work in Support of Regulatory Programs. 2006. Pacific Northwest National Laboratory. Available online at http://etd.pnl.gov/docs/conducting-work/index.stm

CERCLA - Comprehensive Environmental Response, Compensation, and Liability Act. 1980. Public Law 96-150, as amended, 94 Stat. 2767, 42 USC 9601 et seq. 
DOE Guide 414.1-3. 2004, as amended. Suspect/Counterfeit Items Guide for Use with 10 CFR 830 Subpart A, Quality Assurance Requirements, and DOE O 414.1B. U.S. Department of Energy, Washington, D.C.

DOE Order 414.1C. 2005, as amended. Quality Assurance. U.S. Department of Energy, Washington, D.C.

DOE Order 435.1. 2001, as amended. Radioactive Waste Management. U.S. Department of Energy, Washington, D.C.

DOE Order 450.1. 2003, as amended. Environmental Management System. U.S. Department of Energy, Washington, D.C.

DOE Order 5400.5. 1993, as amended. Radiation Protection of the Public and the Environment. U.S. Department of Energy, Washington, D.C.

DOE/EH-94007658. 1993. Remedial Investigation/Feasibility Study (RI/FS) Process, Elements, and Techniques Guidance. U.S. Department of Energy, Washington, D.C.

DOE/RL-96-68. 2007. Hanford Analytical Services Quality Assurance Requirements Documents. HASQARD, Volumes 1, 2, 3, and 4. U.S. Department of Energy, Richland Operations Office, Richland, Washington.

DOE/RL-2005-96. 2006. Strontium-90 Treatability Test Plan for 100-NR-2 Groundwater Operable Unit. Revision 0. U.S. Department of Energy, Richland Operations Office, Richland, Washington.

Ecology - Washington State Department of Ecology. 1994, as amended. Hanford Facility Resource Conservation and Recovery Act Permit, Dangerous Waste Portion Revision 8 for the Treatment, Storage, and Disposal of Dangerous Waste, Permit Number: WA7890008967. Olympia, Washington.

Ecology - Washington State Department of Ecology, U.S. Environmental Protection Agency, and U.S. Department of Energy. 1989, as amended. Hanford Federal Facility Agreement and Consent Order. Document No. 89-10 (The Tri-Party Agreement), Olympia, Washington.

EMSL-LV-0539-17. 1979. Radiochemical Analytical Procedures for Analysis of Environmental Samples. U.S. Environmental Protection Agency, Las Vegas, Nevada.

EPA/240/B-01/003. 2001. EPA Requirements for Quality Assurance Project Plans (QA/R-5).

U.S. Environmental Protection Agency, Washington, D.C.

EPA/240/B-06/001. 2006. Guidance on Systematic Planning Using the Data Quality Objectives Process $(Q A / G-4)$. U.S. Environmental Protection Agency, Washington, D.C.

EPA/540/G-89/004. 1988. Guidance for Conducting Remedial Investigations and Feasibility Studies Under CERCLA. U.S. Environmental Protection Agency, Washington, D.C.

EPA-600/4-79/019. 1979. Handbook for Analytical Quality Control in Water and Wastewater Laboratories. U.S. Environmental Protection Agency, Cincinnati, Ohio.

EPA-600/4-79-020. 1983. Methods for Chemical Analysis of Water and Wastes. U.S. Environmental Protection Agency, Washington, D.C. 
EPA-600/4-80-032. 1980. Prescribed Procedures for Measurement of Radioactivity in Drinking Water. U.S. Environmental Protection Agency, Cincinnati, Ohio.

EPA-600/4-88-039. 1988. Methods for the Determination of Organic Compounds in Drinking Water. U.S. Environmental Protection Agency, Washington, D.C.

EPA-R4-73-014. 1973. Procedures for Radiochemical Analysis of Nuclear Reactor Aqueous Solutions. U.S. Environmental Protection Agency, Cincinnati, Ohio.

EPA/SW-846. 1986, as amended. Test Methods for Evaluating Solid Waste: Physical/Chemical Methods, SW-846, Third Edition. Office of Solid Waste and Emergency Response, U.S. Environmental Protection Agency, Washington, D.C. Available online at http://www.epa.gov/epaoswer/hazwaste/test/main.htm

ESL QAP. Environmental Sciences Laboratory QA Plan, current revision. Pacific Northwest National Laboratory, Richland, Washington.

HNF-PRO-259. 2008. Quality Assurance, Graded Approach, Revision 1, CH2M Hill Plateau Remediation Company, LLC, Richland, Washington.

Johnson TC, FD Day-Lewis, K Singha, CD Johnson, RJ Versteeg, and JW Lane, Jr. 2008. Best Practices for Crosshole Electrical Resistivity Tomography. U.S. Geological Survey, Storrs, Connecticut (in process).

National Water Well Association. 1986. RCRA Ground Water Monitoring Technical Enforcement Guidance Document. Dublin, Ohio.

NQA-1-2000. 2001. Quality Assurance Requirements for Nuclear Facility Applications. The American Society of Mechanical Engineers, New York, New York.

PAAA-Price-Anderson Amendments Act. Energy Policy Act of 2005. Title VI-Nuclear Matters, Subtitle A-Price-Anderson Act Amendments, Section 601 et. seq. Public Law 109-58, as amended. 42 USC 15801 et seq.

PNL-MA-567. 1993, as amended. Procedures for Ground-Water Investigations. Pacific Northwest National Laboratory, Richland, Washington.

PNL-MA-580. 2004, as amended. Surface Environmental Surveillance Procedures Manual, Revision 4. Pacific Northwest National Laboratory, Richland, Washington.

PNNL 1999. Treatability Studies. Standards-Based Management System, Pacific Northwest National Laboratory, Richland, Washington. Available online at http://sbms.pnl.gov/standard/3z/3z00t010.htm

PNNL. 2000. Laboratory Record Books. Standards-Based Management System, Pacific Northwest National Laboratory, Richland, Washington. Available online at http://sbms.pnl.gov/standard/21/2100t010.htm

PNNL. 2002. Training Design, Development, Implementation and Evaluation. Standards-Based Management System, Pacific Northwest National Laboratory, Richland, Washington. Available online at http://sbms.pnl.gov/standard/1f/1f00t010.htm 
PNNL. 2004. Procedures, Permits, and Other Work Instructions. Standards-Based Management System, Pacific Northwest National Laboratory, Richland, Washington. Available online at http://sbms.pnl.gov/standard/74/7400t010.htm

PNNL. 2005a. Calibration. Standards-Based Management System, Pacific Northwest National Laboratory, Richland, Washington. Available online at http://sbms.pnl.gov/standard/79/7900t010.htm

PNNL. 2005b. Training and Qualification for Staff and Non-Staff. Standards-Based Management System, Pacific Northwest National Laboratory, Richland, Washington. Available online at http://sbms.pnl.gov/standard/1e/1e00t010.htm

PNNL. 2006a. Battelle Policies and Standards. Standards-Based Management System, Pacific Northwest National Laboratory, Richland, Washington. Available online at http://sbms.pnl.gov/private/policies/bp00t010.htm

PNNL. 2006b. Document Control. Standards-Based Management System, Pacific Northwest National Laboratory, Richland, Washington. Available online at http://sbms.pnl.gov/standard $/ 2 \mathrm{~m} / 2 \mathrm{~m} 00 \mathrm{t} 010 . \mathrm{htm}$

PNNL 2006c, Electrical Equipment: Designing, Purchasing, and Installing. Standards-Based Management System, Pacific Northwest National Laboratory, Richland, Washington. Available online at http://sbms.pnl.gov/standard/5j/5j00t010.htm

PNNL. 2006d. Suspect/Counterfeit Items and Misrepresented Products, Reporting and Handling. Pacific Northwest National Laboratory, Richland, Washington. Available online at http://sbms.pnl.gov/standard/2t/2t00t010.htm.

PNNL 2007a. Hazardous Materials, Packaging and Shipping. Standards-Based Management System, Pacific Northwest National Laboratory, Richland, Washington. Available online at http://sbms.pnl.gov/standard/66/6600t010.htm

PNNL. 2007b. Publishing Scientific and Technical Information. Standards-Based Management System, Pacific Northwest National Laboratory, Richland, Washington. Available online at http://sbms.pnl.gov/standard/80/8000t010.htm

PNNL. 2007c. Sample Handling, Archival, and Disposal. Standards-Based Management System, Pacific Northwest National Laboratory, Richland, Washington. Available online at http://sbms.pnl.gov/standard/2h/2h00t010.htm

PNNL. 2007d. Software. Standards-Based Management System, Pacific Northwest National Laboratory, Richland, Washington. Available online at http://sbms.pnl.gov/standard/94/9400t010.htm

PNNL. 2008a. Assessment Management. Standards-Based Management System, Pacific Northwest National Laboratory, Richland, Washington. Available online at http://sbms.pnl.gov/standard/4i/4i00t010.htm

PNNL. 2008b. Issues Management. Standards-Based Management System, Pacific Northwest National Laboratory, Richland, Washington. Available online at http://sbms.pnl.gov/standard/5i/5i00a010.htm

PNNL. 2008c. Procurement. Standards-Based Management System, Pacific Northwest National Laboratory, Richland, Washington. Available online at http://sbms.pnl.gov/standard/6c/6c00t010.htm 
PNNL. 2008d. Purchase Orders/Subcontracts. Standards-Based Management System, Pacific Northwest National Laboratory, Richland, Washington. Available online at http://sbms.pnl.gov/standard/3i/3i00t010.htm

PNNL. 2008e. Purchasing Cards (P-Cards). Standards-Based Management System, Pacific Northwest National Laboratory, Richland, Washington. Available online at http://sbms.pnl.gov/standard/1v/1v00t010.htm

PNNL. 2008f. Purchasing Through the Business-to-Business Program. Standards-Based Management System, Pacific Northwest National Laboratory, Richland, Washington. Available online at http://sbms.pnl.gov/standard/4u/4u00t010.htm

PNNL. 2008g. Records Management. Standards-Based Management System, Pacific Northwest National Laboratory, Richland, Washington. Available online at http://sbms.pnl.gov/standard/1a/1a00t010.htm

PNNL. 2008h. Reporting Noncompliances with DOE Requirements for Nuclear Safety and Worker Safety and Health. Standards-Based Management System, Pacific Northwest National Laboratory, Richland, Washington. Available online at http://sbms.pnl.gov/standard/11/1100t010.htm

PNNL. 2008i. Safety Software. Standards-Based Management System, Pacific Northwest National Laboratory, Richland, Washington. Available online at http://sbms.pnl.gov/standard/6e/6e00t010.htm

PNNL. 2008j. Waste, Managing. Standards-Based Management System, Pacific Northwest National Laboratory, Richland, Washington. Available online at http://sbms.pnl.gov/standard/0f/0f00t010.htm

RCRA - Resource Conservation and Recovery Act. 1976. Public Law 94-580, as amended, 90 Stat. 2795,42 USC 6901 et seq.

U.S. Geological Survey. 1977. National Handbook of Recommended Methods for Water Data Acquisition. Office of Water Data Coordination. Reston, Virginia.

WAC 173-160. "Minimum Standards for Construction and Maintenance of Wells." Washington Administrative Code, Olympia, Washington. 


\section{Appendix A}

The CHPRC Columbia River Protection Project

Quality Control Plan 



\section{Appendix A}

\section{The CHPRC Columbia River Protection Project Quality Control Plan}

\section{A.1 Introduction}

This appendix describes the basic methods and procedures to implement a quality control task for sampling and analysis conducted in association with the CH2M Hill Plateau Remediation Company, LLC (CHPRC) Columbia River Protection Project (Columbia River Project). The quality control (QC) practices described in this plan help to evaluate whether samples free of contamination are obtained during sampling and that the laboratory performed sample analyses within the accuracy and precision limits required by the project.

Most of the information in this appendix applies only to groundwater samples. QC practices and requirements that pertain to soil and sediment samples are described in Section A.5.

The primary objectives of this plan are listed below:

1. Identify the QC elements selected for the Columbia River Project

2. Provide data quality objectives (DQO) for reporting limits, precision, accuracy, and completeness

3. Indicate actions that are to be taken for out of tolerance data.

\section{A.2 Technical Requirements}

The technical requirements for QC are divided into two types - components that provide checks on field and laboratory activities (Field QC) and factors that help to monitor laboratory performance (Laboratory QC). Each type of QC sample has required frequencies and acceptance criteria.

The following guidance documents were used as aids in determining the QC elements necessary for the Columbia River Project:

1. Quality Assurance Manual for the Waste Management Branch Investigations (EPA 910/9-86-00).

2. Resource Conservation and Recovery Act (RCRA) Groundwater Monitoring Technical Enforcement Guidance Document (EPA/OSWER-9950.1).

3. Test Methods for Evaluating Solid Waste: Physical/Chemical Methods, SW-846, Third Edition (EPA/SW-846).

4. Handbook for Analytical Quality Control in Water and Wastewater Laboratories (EPA-600/4-79-019).

5. Hanford Analytical Services Quality Assurance Requirements Documents ([HASQARD] DOE/RL-96-68). 
QC elements were selected based on the needs of the project and value that results from each type of sample will add to the database.

\section{A.2.1 Field Quality Control}

To indicate whether samples are collected in a consistent manner and are properly preserved, three types of QC samples will be collected before or during sampling:

1. Sampling Event Blanks - These samples will be prepared by the sampling team before traveling to a sampling site. A preserved bottle set, identical to the set that will be used for sample collection in the field, will be filled with reagent water (carbon free, deionized water). Dead water from well 699-S11-E12AP is used for low-level tritium. The bottles will be sealed by the sampling team and transported unopened to the field in the same storage container that will be used for the samples collected that day. These samples will be typically analyzed for the same constituents as the samples from the associated well.

2. Equipment Blanks - Reagent water will be passed through the pump or manifold after decontamination (sometimes just prior to sampling) to collect blank samples identical to a set that will be collected in the field. Preserved bottles will be used. The equipment blank bottles will be placed in the same container as the associated field samples and not removed from the container until delivery to the laboratory.

3. Field Duplicates - A replicate sample that is collected at one well. After each type of bottle is filled, a second, identical bottle will be filled for each type of analysis as directed by chain-of-custody requirements. Both sets of samples will be stored and transported together.

Using several types of field blank samples provides checks on bottle cleanliness, preservative purity, equipment decontamination, proper storage and transport of samples, and reveals whether or not samples may have been contaminated during collection. Sampling in replicate provides information about sampling reproducibility. Field QC sample frequencies are shown in Table A.1. In addition to the evaluation characteristics described in Table A.1, the field QC samples also provide a check on the analytical results. The field QC data are designed to give an overall impression of the performance of the sampling and analysis of the Columbia River Project; however, individual data points associated with field QC samples that are outside of the acceptance criteria are flagged in the database.

The results of each type of field QC sample are evaluated according to criteria defined in Table A.2. 
Table A.1. Quality Control Samples

\begin{tabular}{|c|c|c|}
\hline \multicolumn{3}{|c|}{ Field Quality Control } \\
\hline Sample Event Blank & Contamination from containers or transportation & 1 per 20 wells sampled \\
\hline Equipment Blank & Contamination from non-dedicated equipment & As needed(a) \\
\hline Replicate/Duplicate Samples & Reproducibility & 1 per 20 wells sampled \\
\hline \multicolumn{3}{|c|}{ Laboratory Quality Control } \\
\hline Sample Type & Primary Characteristics Evaluated & Frequency \\
\hline Method Blanks & Laboratory Contamination & 1 per batch \\
\hline Lab Duplicates & Laboratory Reproducibility & (b) \\
\hline Matrix Spikes & Matrix Effect and Laboratory Accuracy & (b) \\
\hline Matrix Spike Duplicates & Laboratory Reproducibility/Accuracy & (b) \\
\hline Surrogates & Recovery/Yield & (b) \\
\hline Laboratory Control Samples & Method Accuracy & 1 per batch \\
\hline \multicolumn{3}{|c|}{$\begin{array}{l}\text { (a) For portable Grundfos pumps, equipment blanks are collected one per ten well trips. Whenever a new type of non-dedicated } \\
\text { equipment is used, an equipment blank shall be collected every time sampling occurs until it can be shown that less frequent } \\
\text { collection of equipment blanks is adequate to monitor the decontamination procedure for the non-dedicated equipment. } \\
\text { (b) As defined in the laboratory contract or QA plan and/or analysis procedures. }\end{array}$} \\
\hline
\end{tabular}

Table A.2. Field and Laboratory QC Elements and Acceptance Criteria

\begin{tabular}{|c|c|c|c|}
\hline Method & QC Element & Acceptance Criteria & Corrective Action \\
\hline \multicolumn{4}{|c|}{ General Chemical Parameters } \\
\hline \multirow{8}{*}{$\begin{array}{l}\text { Alkalinity - EPA } 600 \text { Series, } 310.1 \\
\text { Chemical Oxygen Demand - EPA } 600 \text { Series, } 410.4 \\
\text { Conductivity - EPA } 600 \text { Series, } 120.1 \\
\text { Oil and Grease - EPA } 600 \text { Series, } 413.1 \\
\text { pH - EPA } 600 \text { Series, } 150.1 \\
\text { Total Dissolved Solids - EPA } 600 \text { Series, } 160.1 \\
\text { Total Organic Carbon - EPA/SW-846, as amended, } \\
9060 \\
\text { Total Organic Halides - EPA/SW-846, as amended, } \\
9020\end{array}$} & $\mathrm{MB}(\mathrm{a})$ & $<\mathrm{MDL}$ & Flagged with "C" \\
\hline & LCS & $80-120 \%$ recovery(b) & Data reviewed(c) \\
\hline & DUP & $\pm 20 \% \mathrm{RPD}(\mathrm{b})$ & Data reviewed(c) \\
\hline & $\operatorname{MS}(d)$ & $75-125 \%$ recovery $(b)$ & Flagged with "N" \\
\hline & $\mathrm{EB}, \mathrm{FTB}$ & $<2 \mathrm{X}$ MDL & Flagged with "Q" \\
\hline & Field Duplicate & $\pm 20 \% \mathrm{RPD}(\mathrm{e})$ & Flagged with "Q" \\
\hline & & & \\
\hline & & & \\
\hline \multicolumn{4}{|c|}{ Ammonia and Anions } \\
\hline \multirow{6}{*}{$\begin{array}{l}\text { Ammonia - EPA } 600 \text { Series, } 350.1 \\
\text { Anions by IC - EPA } 600 \text { Series, } 300.0 \\
\text { Cyanide - EPA/SW-846, as amended, } 9012\end{array}$} & MB & $<\mathrm{MDL}$ & Flagged with "C" \\
\hline & LCS & $80-120 \%$ recovery(b) & Data reviewed(c) \\
\hline & DUP & $\pm 20 \% \mathrm{RPD}(\mathrm{b})$ & Data reviewed(c) \\
\hline & MS & $75-125 \%$ recovery $(b)$ & Flagged with "N" \\
\hline & EB, FTB & $<2 \mathrm{X}$ MDL & Flagged with "Q" \\
\hline & Field Duplicate & $\pm 20 \% \mathrm{RPD}(\mathrm{e})$ & Flagged with "Q" \\
\hline
\end{tabular}


Table A.2. (contd)

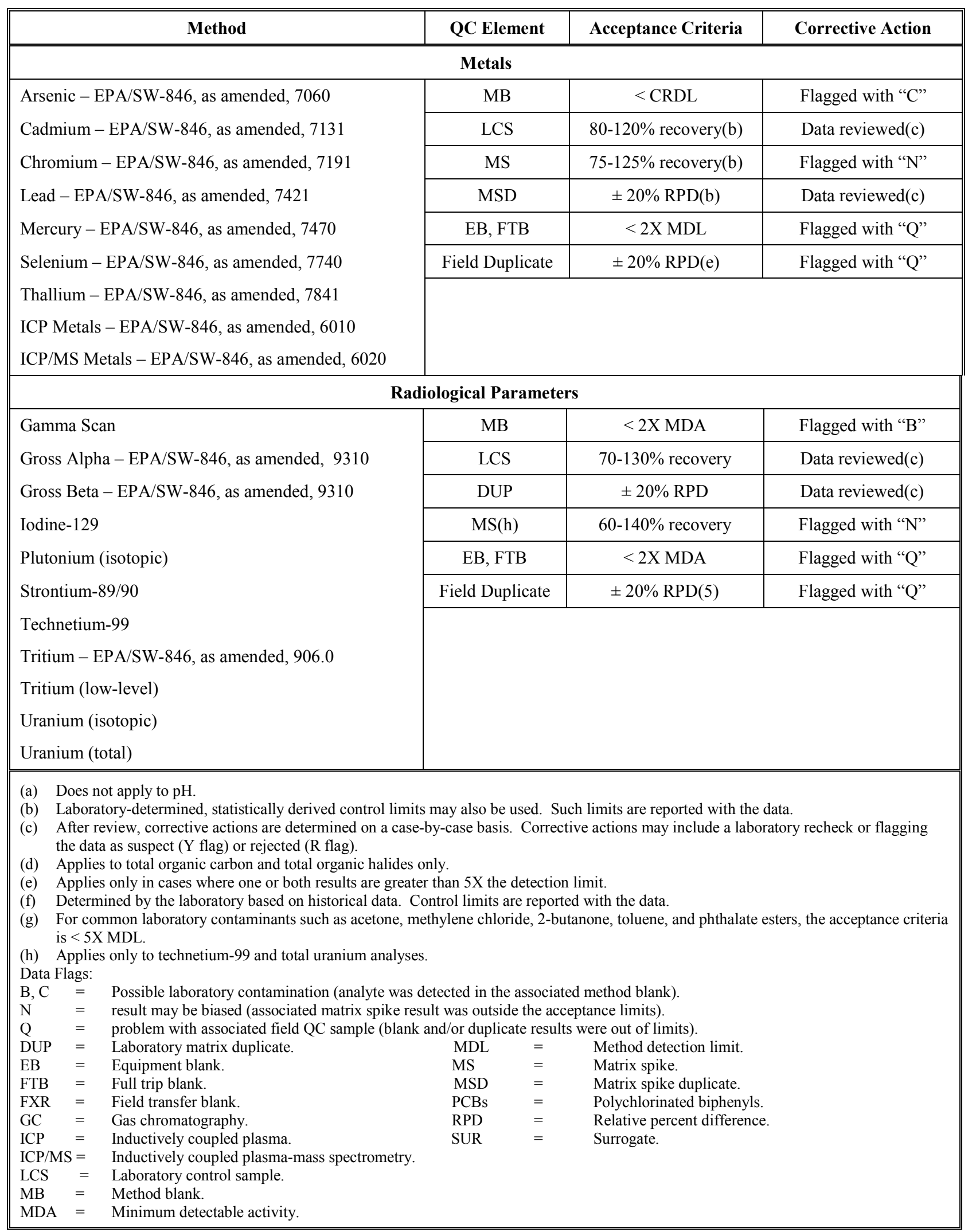


Bias will be assessed by comparing a measured value to a known or accepted reference value or the recovery of a known amount of spiked contaminant into a sample (i.e., a matrix spike). For a matrix spike (MS) bias caused by matrix effects will be calculated as follows in Equation (A.1):

$$
\mathrm{B}=\left(\mathrm{X}_{\mathrm{s}}-\mathrm{X}_{\mathrm{u}}\right)-\mathrm{K}
$$

Where

$$
\begin{aligned}
& \mathrm{X}_{\mathrm{s}}=\text { measured value of spiked sample } \\
& \mathrm{X}_{\mathrm{u}}=\text { sample or miscellaneous contribution } \\
& \mathrm{K}=\text { known value of spike }
\end{aligned}
$$

Using Equation (A.2) yields percent recovery (\%R):

$$
\% \mathrm{R}=100\left(\mathrm{X}_{\mathrm{s}}-\mathrm{X}_{\mathrm{u}}\right) / \mathrm{K}
$$

Analytical precision will be determined by analyzing duplicates (field or lab). Precision is expressed as either percent relative standard deviation (RSD) or relative percent difference (RPD). Duplicate results will be flagged if the results of both samples are quantifiable (i.e., the result is greater than the five times the instrument detection limit [IDL]/method detection limit [MDL]/minimum detectable activity [MDA]) and the RPD is greater than 20\%. The RPD is calculated as follows in Equation (A.3):

$$
R P D=\frac{D_{1}-D_{2}}{\left(D_{1}+D_{2}\right) / 2} \times 100
$$

Where

$\mathrm{D}_{1}=$ original sample value

$\mathrm{D}_{2}=$ duplicate sample value

When more than two data values are present, precision is calculated by the RSD as shown in Equation (A.4):

$$
\mathrm{RSD}=\frac{\text { standard deviation }}{\text { mean }} \times 100
$$

\section{A.2.2 Quality Control in the Laboratory}

The ability to perform sample analyses within the limits established by the project will be monitored in several ways. This QAPjP governs laboratory work performed by staff participating in the Columbia River Project. The work activities in the laboratories will be periodically reviewed, including selected laboratories of subcontracted Columbia River Project collaborators. The laboratory QA effort includes a comprehensive quality control program, which includes the use of matrix spikes, matrix duplicates, matrix spike duplicates, laboratory control samples, surrogates, tracers, and blanks. These samples are recommended in the guidance documents and are required by U.S. Environmental Protection Agency (EPA) protocol.

- Matrix Duplicate (MD) - An intra-laboratory split sample used to evaluate the precision of a method in a given sample matrix. 
- Matrix Spike (MS) - An aliquot of a sample spiked with a known concentration of target analyte(s). The MS will be used to assess the bias of a method in a given sample matrix. Spiking will be done prior to sample preparation and analysis.

- Matrix Spike Duplicate (MSD) - A replicate spiked aliquot of a sample subjected to the entire sample preparation and analytical process. The results from these samples will be used to determine the bias and precision of a method in a given sample matrix.

- Laboratory Control Sample (LCS) - A control matrix spike (e.g., deionized water) spiked with analytes representative of the target analytes or a certified reference material used to evaluate laboratory accuracy.

- Method Blank - An analyte-free matrix to which all reagents are added in the same volumes or proportions as used in sample processing. The method blank will be carried through the complete sample preparations and analytical procedure, and used to quantify contamination resulting from the analytical process.

- Tracers - A tracer is a known quantity of a chemical or radioactive isotope that is different from that of the isotope of interest but is expected to behave similarly and is added to an aliquot of sample. Sample results are generally corrected based on tracer recovery.

The samples are analyzed within the holding times specified by the analysis procedure. In some instances, constituents in samples not analyzed within the holding time may be compromised by volatilization, decomposition or other chemical changes. Data from samples analyzed outside the holding time are flagged in the EM-20 database with an $\mathrm{H}$. The holding times for constituents analyzed by the Columbia River Project are listed in Table A.3.

Other tools are used by the project to evaluate analytical work. Double-blind standards of the constituents of concern will be used to evaluate laboratory performance. Because the results of double-blind standards provide information on laboratory precision and accuracy, these standards are useful tools to verify that the project DQOs are being met. Table A.4 lists the typical blind-standard constituents. The list of constituents is subject to change based on need. Specific information about the constituents used and their spiking levels will be maintained in project files.

Blind standards are prepared by spiking matrix groundwater and deionized water with known concentrations of constituents of interest. Spiking concentrations range from MDA or MDL, depending on the constituent measured, to the upper limit of concentration determined in groundwater on the Hanford Site. The matrix groundwater wells chosen are 699-49-100C for radiochemical analytes, and total organic halides (TOX); and 699-19-88 for cyanide, anions, inductively coupled plasma (ICP) metals, and total organic carbon (TOC). Deionized water is used to prepare VOCs. Well 699-49-100C is located to the west of the Hanford Site. Well 699-19-88 is a southern boundary well. Both wells are considered free of the contaminant migration zone. Dead water from well 699-S11-E12AP is used to prepare low-level tritium blind standards.

Blind-standard results are evaluated by comparing the laboratory results to the actual spike values. Laboratory precision is also considered as the samples are sent to the laboratory in replicate. Laboratory results are evaluated based on the recovery and precision criteria listed in Table A.4. Results outside of these control limits are investigated and appropriate actions are taken, if necessary. 
Table A.3. Columbia River Project Holding Times

\begin{tabular}{|l|l|l||}
\hline \multicolumn{1}{|c|}{ Constituents } & \multicolumn{1}{c|}{ Methods $^{(\mathbf{a})}$} & \multicolumn{1}{c|}{ Holding Times } \\
\hline \hline ICP metals & SW-846, 6010 & 6 months \\
\hline ICP-MS & SW-846, 6020 & 6 months \\
\hline Arsenic & SW-846, 7060 & 6 months \\
\hline Lead & SW-846, 7421 & 6 months \\
\hline Mercury & SW-846, 7470/7471 & 28 days \\
\hline Selenium & SW-846, 7740 & 6 months \\
\hline Thallium & SW-846, 7841 & 6 months \\
\hline Alkalinity & EPA 600 Series, 310.1 & 14 days \\
\hline Cyanide & SW-846, 9010/9012 & 14 days \\
\hline Bromide & EPA 600 Series, 300.0 & 28 days \\
\hline Chloride & EPA 600 Series, 300.0 & 28 days \\
\hline Fluoride & EPA 600 Series, 300.0 & 28 days \\
\hline Nitrate & EPA 600 Series, 300.0 & 48 hours \\
\hline Nitrite & EPA 600 Series, 300.0 & 48 hours \\
\hline Phosphate & EPA 600 Series, 300.0 & 48 hours \\
\hline Sulfate & EPA 600 Series, 300.0 & 28 days \\
\hline Total organic carbon & SW-846, 9060 & 28 days \\
\hline Total organic halides & SW-846, 9020 & 28 days \\
\hline Chemical oxygen demand & EPA 600 Series, 410.4 & 28 days \\
\hline \hline $\begin{array}{l}\text { (a) EPA/SW-846, as amended. } \\
\text { ICP/MS }=\text { Inductively coupled plasma-mass spectrometry. }\end{array}$ & \\
\hline \hline & & \\
\hline
\end{tabular}


Table A.4. Blind-Standard Constituents and Schedule

\begin{tabular}{|c|c|c|}
\hline Constituents & Recommended Recovery (\%) ${ }^{(\mathrm{a})}$ & Precision $\left(\%\right.$ RSD) ${ }^{(\mathrm{a})}$ \\
\hline Fluoride & $\pm 25 \%$ & $\pm 25 \%$ \\
\hline Nitrate & $\pm 25 \%$ & $\pm 25 \%$ \\
\hline Cyanide & $\pm 25 \%$ & $\pm 25 \%$ \\
\hline Chromium & $\pm 20 \%$ & $\pm 20 \%$ \\
\hline Total Organic Carbon ${ }^{(\mathrm{b})}$ & Varies according to spiking compound & Varies according to spiking compound \\
\hline Total Organic Halides ${ }^{(\mathrm{c})}$ & Varies according to spiking compound & Varies according to spiking compound \\
\hline Gross alpha $^{(\mathrm{d})}$ & $70-130 \%$ & $\pm 20 \%$ \\
\hline Gross beta $^{(\mathrm{e})}$ & $70-130 \%$ & $\pm 20 \%$ \\
\hline Tritium & $70-130 \%$ & $\pm 20 \%$ \\
\hline Tritium (low level) & $70-130 \%$ & $\pm 20 \%$ \\
\hline Cobalt- 60 & $70-130 \%$ & $\pm 20 \%$ \\
\hline Strontium-90 & $70-130 \%$ & $\pm 20 \%$ \\
\hline Technetium-99 & $70-130 \%$ & $\pm 20 \%$ \\
\hline Iodine-129 & $70-130 \%$ & $\pm 20 \%$ \\
\hline Cesium-137 & $70-130 \%$ & $\pm 20 \%$ \\
\hline Uranium & $70-130 \%$ & $\pm 20 \%$ \\
\hline Plutonium-239/240 & $70-130 \%$ & $\pm 20 \%$ \\
\hline
\end{tabular}

(a) If the results are less than five times the required detection limit, the criteria is that the difference of the results of the replicates is less than the required detection limit.

(b) The spiking compound generally used for total organic carbon (TOC) is potassium phthalate. Other spiking compounds may also be used.

(c) Two sets of spikes for total organic halides (TOX) will be used. The spiking compound for one set should be 2,4,5-trichlorophenol. The spiking compound for the second set should include the constituents used for the volatile organic compounds (VOC) sample (carbon tetrachloride, chloroform, trichloroethylene).

(d) The gross alpha sample will be prepared from $\mathrm{Pu}-239$.

(e) The gross beta sample will be prepared from Sr-90.

$\mathrm{RSD}=$ Relative standard deviation

\section{A.3 Data Quality Objectives}

DQOs are defined for reporting limits, precision, accuracy, and completeness. Groundwater monitoring plans or sampling analysis plans specify whether or not a particular site has more stringent DQOs than those specified in this plan.

Limits for precision and accuracy for chemical analyses are based on criteria stipulated in the methods (e.g., EPA/SW-846, as amended, EPA 600 series). Precision and accuracy limits for radiochemical results are specified in the laboratory contract.

Completeness is defined as the percentage of data points judged to be valid. The percent complete for each quarter should be at least $85 \%$. 
Reporting limits for radiochemical constituents are defined in individual test plans. Reporting limits will be based on research needs, but regulatory reporting limits and actual reporting limits are listed in Table A.5 for radiochemical constituents as a reference point. For chemical constituents, MDLs as low as one-third the EPA drinking water standards are preferred. In some cases, MDLs that are one-third the regulatory limit are not feasible (e.g., pentachlorophenol and cadmium). Because MDLs change frequently, these values are not provided in this document.

\section{A.4 Reporting and Deliverables Requirements}

The results of the blind standards and the field QC samples will be provided through current analytical reporting procedures. The QC analytical results will be reviewed and compiled in the IFC database.

All project records associated with QC are maintained in accordance with the RIDS for the Columbia River Project.

Table A.5. Reporting Limits for Radiochemical Constituents

\begin{tabular}{|c|c|c|c|c|c|}
\hline Constituent of Concern & Method & CAS \# & DWS & 1/3 DWS & RDL \\
\hline Gross Alpha & Gross Alpha-GA & $12587-46-1$ & $15 \mathrm{pCi} / \mathrm{L}^{*}$ & $5 \mathrm{pCi} / \mathrm{L}^{*}$ & $3 \mathrm{pCi} / \mathrm{L}$ \\
\hline Gross Beta & Gross Beta - GB & $12587-47-2$ & N/A & N/A & $4 \mathrm{pCi} / \mathrm{L}$ \\
\hline Cobalt-60 & Gamma Spec & $10198-40-0$ & $100 \mathrm{pCi} / \mathrm{L}$ & $33 \mathrm{pCi} / \mathrm{L}$ & $25 \mathrm{pCi} / \mathrm{L}$ \\
\hline Cesium-137 & -- & $10045-97-3$ & $200 \mathrm{pCi} / \mathrm{L}$ & $67 \mathrm{pCi} / \mathrm{L}$ & $15 \mathrm{pCi} / \mathrm{L}$ \\
\hline Europium-152 & -- & -- & -- & -- & $50 \mathrm{pCi} / \mathrm{L}$ \\
\hline Europium-154 & -- & -- & $200 \mathrm{pCi} / \mathrm{L}$ & $67 \mathrm{pCi} / \mathrm{L}$ & $50 \mathrm{pCi} / \mathrm{L}$ \\
\hline Europium-155 & -- & -- & $600 \mathrm{pCi} / \mathrm{L}$ & $200 \mathrm{pCi} / \mathrm{L}$ & $50 \mathrm{pCi} / \mathrm{L}$ \\
\hline Tritium & $\mathrm{H}-3$ & $10028-17-8$ & $20,000 \mathrm{pCi} / \mathrm{L}$ & $6700 \mathrm{pCi} / \mathrm{L}$ & $400 \mathrm{pCi} / \mathrm{L}$ \\
\hline Tritium & H-3 (LL) & N/A & N/A & N/A & $10 \mathrm{pCi} / \mathrm{L}$ \\
\hline Iodine-129 & $\mathrm{I}-129$ & $10043-66-0$ & $1 \mathrm{pCi} / \mathrm{L}$ & $0.33 \mathrm{pCi} / \mathrm{L}$ & $5 \mathrm{pCi} / \mathrm{L}$ \\
\hline Iodine-129 & I-129 (LL) & N/A & N/A & N/A & $1 \mathrm{pCi} / \mathrm{L}$ \\
\hline Strontium-90 & Sr-89/Sr-90 & $10098-97-2$ & $8 \mathrm{pCi} / \mathrm{L}$ & $2.7 \mathrm{pCi} / \mathrm{L}$ & $2 \mathrm{pCi} / \mathrm{L}$ \\
\hline Technetium-99 & Tc-99 & $14133-76-7$ & $900 \mathrm{pCi} / \mathrm{L}$ & $300 \mathrm{pCi} / \mathrm{L}$ & $15 \mathrm{pCi} / \mathrm{L}$ \\
\hline Plutonium-238 & Isotopic Plutonium & -- & $1.6 \mathrm{pCi} / \mathrm{L}$ & $0.5 \mathrm{pCi} / \mathrm{L}$ & $1 \mathrm{pCi} / \mathrm{L}$ \\
\hline Plutonium-239/240 & Pu-AEA & -- & $1.2 \mathrm{pCi} / 1$ & $0.4 \mathrm{pCi} / \mathrm{L}$ & $1 \mathrm{pCi} / \mathrm{L}$ \\
\hline Constituent of Concern & Method & CAS \# & DWS & $1 / 3 \mathrm{DWS}$ & RDL \\
\hline Uranium-233 & Isotopic Uranium & $13968-55-3$ & $20 \mathrm{pCi} / \mathrm{L}$ & $6.7 \mathrm{pCi} / \mathrm{L}$ & $1 \mathrm{pCi} / \mathrm{L}$ \\
\hline Uranium-234 & Isotopic Uranium & $13966-29-5$ & $20 \mathrm{pCi} / \mathrm{L}$ & $6.7 \mathrm{pCi} / \mathrm{L}$ & $1 \mathrm{pCi} / \mathrm{L}$ \\
\hline Uranium-235 & Uranium-AEA & $15117-96-1$ & $24 \mathrm{pCi} / \mathrm{L}$ & $8 \mathrm{pCi} / \mathrm{L}$ & $1 \mathrm{pCi} / \mathrm{L}$ \\
\hline Uranium-238 & & $\mathrm{U}-238$ & $24 \mathrm{pCi} / \mathrm{L}$ & $8 \mathrm{pCi} / \mathrm{L}$ & $1 \mathrm{pCi} / \mathrm{L}$ \\
\hline $\begin{array}{l}\text { Total alpha energy emitted } \\
\text { from Radium }\end{array}$ & Total Radium & N/A & N/A & $\mathrm{N} / \mathrm{A}$ & $1 \mathrm{pCi} / \mathrm{L}$ \\
\hline Uranium (elemental) & Total Uranium & N/A & $30 \mu \mathrm{g} / \mathrm{L}$ & $10 \mu \mathrm{g} / \mathrm{L}$ & $0.1 \mu \mathrm{g} / \mathrm{L}$ \\
\hline $\begin{array}{l}{ }^{*} \text { Excluding uranium } \\
\text { CAS\# }=\text { Chemical abstract } \\
\text { DWS }=\text { Drinking water sta } \\
\text { N/A }=\text { Not applicable. } \\
\text { RDL }=\text { Required detectior }\end{array}$ & $\begin{array}{l}\text { ice number. } \\
\text { d. }\end{array}$ & & & & \\
\hline
\end{tabular}




\section{A.5 Requirements for Soil and Sediment Samples}

The Columbia River Project will analyze sediment samples in support of site-characterization activities. The nature of this work precludes specification of many of the requirements listed previously for groundwater samples. Therefore, the types, quantities, and acceptance criteria for field and/or laboratory QC samples are specified in the characterization plan and specific test plans for individual experiments. Table A.6 lists the maximum recommended holding times for common analytes in soils. Radionuclides are not included in the table.

Table A.6. Holding Times for Sediment Analyses

\begin{tabular}{|c|c|c|}
\hline Constituents & Methods $^{(a)}$ & Holding Times \\
\hline ICP metals & SW-846, 6010 & 6 months \\
\hline ICP-MS & SW-846, 6020 & 6 months \\
\hline Arsenic & SW-846, 7060 & 6 months \\
\hline Lead & SW-846, 7421 & 6 months \\
\hline Mercury & SW-846, 7470/7471 & 28 days \\
\hline Selenium & SW-846, 7740 & 6 months \\
\hline Thallium & SW-846, 7841 & 6 months \\
\hline Alkalinity & EPA 600 Series, 310.1 & 14 days \\
\hline Cyanide & SW-846, 9010/9012 & 14 days \\
\hline Bromide & EPA 600 Series, 300.0 & 28 days \\
\hline Chloride & EPA 600 Series, 300.0 & 28 days \\
\hline Fluoride & EPA 600 Series, 300.0 & 28 days \\
\hline Nitrate & EPA 600 Series, 300.0 & 48 hours \\
\hline Nitrite & EPA 600 Series, 300.0 & 48 hours \\
\hline Phosphate & EPA 600 Series, 300.0 & 48 hours \\
\hline Sulfate & EPA 600 Series, 300.0 & 28 days \\
\hline Total organic carbon & SW-846, 9060 & 28 days \\
\hline Total organic halides & SW-846, 9020 & 28 days \\
\hline Chemical oxygen demand & EPA 600 Series, 410.4 & 28 days \\
\hline
\end{tabular}




\section{A.6 References}

DOE/RL-96-68. 1998. Hanford Analytical Services Quality Assurance Requirements Documents. (HASQARD), Volumes 1 through 4, U.S. Department of Energy, Richland, Washington.

DOH. 1990. Washington State Environmental Radiation Program Annual Report. Washington State Department of Health, Olympia, Washington.

EPA-600/4-79-019. 1979. Handbook for Analytical Quality Control in Water and Wastewater Laboratories. U.S. Environmental Protection Agency, Cincinnati, Ohio.

EPA 910/9-86-00. 1986. Quality Assurance Manual for Waste Management Branch Investigations. U.S. Environmental Protection Agency, Region 10, Seattle, Washington.

EPA/OWSER-9950.1. 1986. Resource Conservation and Recovery Act (RCRA) Groundwater Monitoring Technical Enforcement Guidance Document. U.S. Environmental Protection Agency, Washington, D.C.

EPA/SW-846. 1986, as amended. Test Methods for Evaluating Solid Waste: Physical/Chemical Methods, SW-846, Third Edition. Office of Solid Waste and Emergency Response, U.S. Environmental Protection Agency, Washington, D.C. Available online at http://www.epa.gov/epaoswer/hazwaste/test/sw846.htm

PNNL-145670. 2006. Hanford Site Groundwater Monitoring for Fiscal Year 2005. MJ Hartman, LF Morasch, and WD Webber (eds.), Pacific Northwest National Laboratory, Richland, Washington. 

Appendix B

Experimental and Modeling Procedures for the Projects 



\section{Appendix B}

\section{Experimental and Modeling Procedures for the Projects}

\begin{tabular}{|c|c|c|c|}
\hline Method & Analysis & Document Number & Procedure Title \\
\hline $\begin{array}{l}\text { Conduct of Routine } \\
\text { Laboratory Operations }\end{array}$ & General & RPL-OP-001 & $\begin{array}{l}\text { "Routine Research } \\
\text { Operations," } \\
\text { Section 31, tab } 3 \text { of } \\
\text { RPL Laboratory Handbook }\end{array}$ \\
\hline $\begin{array}{l}\text { Inductively Coupled } \\
\text { Plasma-Optical Emission } \\
\text { Spectroscopy } \\
\text { (ICP-OES)* }\end{array}$ & $\begin{array}{l}\mathrm{Ca}, \mathrm{K}, \mathrm{Mg}, \mathrm{P}, \mathrm{Sr}, \mathrm{Na}, \mathrm{Si} \\
\mathrm{Cu}, \mathrm{Fe}, \mathrm{Mn}, \mathrm{S} \text {, and } \mathrm{Ti} \text { in } \\
\text { water in ppb or moles } / \mathrm{L}\end{array}$ & PNNL-AGG-ICP-AES ${ }^{\dagger}$ & $\begin{array}{l}\text { Inductively Couple Plasma - } \\
\text { Optical Emission } \\
\text { Spectrometry (ICP-OES) } \\
\text { Analysis }\end{array}$ \\
\hline $\begin{array}{l}\text { Inductively Coupled } \\
\text { Plasma-Mass } \\
\text { Spectroscopy (ICP-MS) }\end{array}$ & $\mathrm{Re}, \mathrm{Tc}$ & PNNL-AGG-415 & $\begin{array}{l}\text { Inductively Coupled Plasma } \\
\text { Mass Spectrometric (ICP-MS) } \\
\text { Analysis }\end{array}$ \\
\hline Ion Chromatography & $\begin{array}{l}\mathrm{F}, \mathrm{Cl}, \mathrm{NO}_{2}, \mathrm{NO}_{3}, \mathrm{CO}_{3}, \\
\mathrm{SO}_{4}, \mathrm{PO}_{4}, \mathrm{PO}_{4} \text { in water } \\
\text { in } \mathrm{ppm}_{\text {or moles} / \mathrm{L}}\end{array}$ & *PNNL-AGG-IC-001 & $\begin{array}{l}\text { Determinations by Ion } \\
\text { Chromatography (IC) }\end{array}$ \\
\hline $\mathrm{ICP} / \mathrm{MS}$ & $\begin{array}{l}\mathrm{Cu}, \mathrm{Fe} \text { in water in ppb or } \\
\text { moles/L }\end{array}$ & $\begin{array}{l}\text { PNL-SAND-3.1 (needs to } \\
\text { be updated) }\end{array}$ & -- \\
\hline KPA & $\begin{array}{l}\mathrm{U} \text { in water in ppb or } \\
\text { moles/L }\end{array}$ & Liu et al. (2004) & -- \\
\hline Spectrophotometer & $\mathrm{Fe}(\mathrm{II})$ and total $\mathrm{Fe}$ in $\mathrm{ppb}$ & Kukkadapu et al. (2004) & -- \\
\hline LSC & $\begin{array}{l}\text { Sr-90, Tc-99, I-129, in } \\
\mathrm{dpm} / \mathrm{mL}\end{array}$ & $\begin{array}{l}\text { *PNNL-AGG-RRL-002; } \\
\text { Procedures vary slightly } \\
\text { for different } \\
\text { radioisotopes; McKinley } \\
\text { et al. (2007) for Sr-90 }\end{array}$ & -- \\
\hline $\begin{array}{l}\text { Solid-State } \mathrm{pH} \text { Electrode } \\
\text { and Meter }\end{array}$ & $\mathrm{pH}$, Bromide & AGG-PH-001 & pH Measurement \\
\hline X-Ray Diffraction (XRD) & Mineralogy & RPL-XRD-PIP & $\begin{array}{l}\text { Operation of Scintag Pad-V } \\
\text { X-Ray Diffractor (RGD \#62) }\end{array}$ \\
\hline $\begin{array}{l}\text { Scanning Electron } \\
\text { Microscopy/Energy- } \\
\text { Dispersive X-Ray } \\
\text { Spectrometry } \\
\text { (SEM/EDS) }\end{array}$ & $\begin{array}{l}\text { Particle morphology, } \\
\text { size, and qualitative } \\
\text { elemental analysis }\end{array}$ & PNL-SP-3 & $\begin{array}{l}\text { Scanning Electron } \\
\text { Microscopy/Energy } \\
\text { Dispersive Spectrometry }\end{array}$ \\
\hline Particle-Size Distribution & -- & PNL-MA-567, SA-3 & $\begin{array}{l}\text { Particle-size analysis (pipette } \\
\text { or hydrometer method); } \\
\text { wet-sieve analysis will be } \\
\text { used to remove sand-size } \\
\text { particles }\end{array}$ \\
\hline
\end{tabular}




\begin{tabular}{|c|c|c|c|}
\hline Method & Analysis & Document Number & Procedure Title \\
\hline Hydraulic Conductivity & -- & PNL-MA-567, SA-5 & $\begin{array}{l}\text { Falling head hydraulic } \\
\text { conductivity }\end{array}$ \\
\hline Water Retention & -- & UFA-SK-01 & $\begin{array}{l}\text { Determination of water } \\
\text { retention as a function of } \\
\text { water content using open-flow } \\
\text { centrifugation techniques }\end{array}$ \\
\hline Water Content & -- & PNL-MA-567, SA-7 & Water content \\
\hline Bulk Density & -- & PNL-MA-567, SA-8 & Clod density/bulk density \\
\hline Particle Density & -- & PNL-MA-567, SA-9 & $\begin{array}{l}\text { Determining particle density; } \\
\text { necessary for constant head } \\
\text { hydraulic conductivity }\end{array}$ \\
\hline Column Packing & -- & $\begin{array}{l}\text { WHC-IP-0635, GEL-3 } \\
\text { Rev.3 }\end{array}$ & $\begin{array}{l}\text { Moisture relationships of } \\
\text { soils; necessary for constant } \\
\text { head hydraulic conductivity }\end{array}$ \\
\hline $\mathrm{pH} / \mathrm{EC}$ & -- & PNL-G-5-pH/EC & $\begin{array}{l}\text { Measuring } \mathrm{pH} / \mathrm{EC} \text { of low- } \\
\text { level radioactive solutions }\end{array}$ \\
\hline $\begin{array}{l}\text { Saturated column } \\
\text { experiments }\end{array}$ & -- & AGG-SAT-COL-001 & $\begin{array}{l}\text { Conducting saturated column } \\
\text { experiments }\end{array}$ \\
\hline Batch experiments & -- & AGG-BSE-001 & Batch sorption experiments \\
\hline Surface Area & -- & AGG-SA-001 & Measuring surface area \\
\hline TIC/TOC & $\begin{array}{l}\text { Inorganic } \mathrm{C} \text {, organic } \mathrm{C} \text {, } \\
\text { total } \mathrm{C}\end{array}$ & *PNNL-AGG-TOC-001 & -- \\
\hline X-ray Fluorescence & $\begin{array}{l}\text { Total analyses of } \\
\text { sediments including } \mathrm{Al} \text {, } \\
\mathrm{Si}, \mathrm{K}, \mathrm{Ca}, \mathrm{Mg}, \mathrm{Sr}, \mathrm{Ti}, \mathrm{Fe} \text {, } \\
\mathrm{Mn}, \mathrm{Cu}, \mathrm{Ni}, \mathrm{Cr}, \mathrm{Cs}, \mathrm{U}, \\
\text { and others. }\end{array}$ & $\begin{array}{l}\text { *PNNL-AGG-OP- } \\
\text { RGD74-001 }\end{array}$ & -- \\
\hline $\begin{array}{l}\text { Conventional Powder X- } \\
\text { ray Diffraction }\end{array}$ & $\begin{array}{l}\text { Mineral identity (\% } \\
\text { distribution) }\end{array}$ & Qafoku et al. (2005) & -- \\
\hline Digital Autoradiography & $\begin{array}{l}\text { Identify locations of } \\
\text { radioactivity in sediment } \\
\text { thin section and mixtures } \\
\text { of sand and silt-sized } \\
\text { particles. }\end{array}$ & $\begin{array}{l}\text { Zeissler et al. (2001); } \\
\text { McKinley et al. (2001) }\end{array}$ & -- \\
\hline $\begin{array}{l}\text { Scanning Electron } \\
\text { Microscopy } \\
\text { with WDS }\end{array}$ & $\begin{array}{l}\text { High resolution imaging } \\
\text { of particle morphology } \\
\text { and atomic mass } \\
\text { generally in sediment } \\
\text { thin section; semi } \\
\text { quantitative imaging of } \\
\text { chemical distribution. }\end{array}$ & McKinley et al. (2006) & -- \\
\hline $\begin{array}{l}\text { Transmission Electron } \\
\text { Microscopy with } \\
\text { Selected Area Diffraction } \\
\text { (SAED) }\end{array}$ & $\begin{array}{l}\text { Very high resolution of } \\
\text { single mineral grains in } \\
\text { cross section; local } \\
\text { morphology, structure } \\
\text { and atomic arrangement. }\end{array}$ & $\begin{array}{l}\text { Zachara et al. (2006). } \\
\text { Selected area diffraction } \\
\text { patterns are interpreted } \\
\text { using the JADE software } \\
\text { (see below) using x-ray } \\
\text { powder diffraction data } \\
\text { (PDF) retrieved from a } \\
\text { standards library (ICDD } \\
\text { 2003) }\end{array}$ & -- \\
\hline
\end{tabular}




\begin{tabular}{|c|c|c|c|}
\hline Method & Analysis & Document Number & Procedure Title \\
\hline Electron microprobe & $\begin{array}{l}\text { Quantitative, } \\
\text { intermediate sensitivity } \\
\text { chemical mapping in } \\
\text { thin sections. Chemical } \\
\text { transects across } \\
\text { grain/particle } \\
\text { boundaries. }\end{array}$ & $\begin{array}{l}\text { Wang et al. (2005b); } \\
\text { Catalano et al. (2006) }\end{array}$ & -- \\
\hline $\begin{array}{l}\text { X-ray fluorescence } \\
\text { microprobe }\end{array}$ & $\begin{array}{l}\text { High sensitivity, semi } \\
\text { quantitative mapping of } \\
\text { element distributions in } \\
\text { sediment thin sections at } \\
\text { scales of } 10 \mu \mathrm{m} \text {. }\end{array}$ & $\begin{array}{l}\text { Liu et al. (2004); } \\
\text { Fredrickson et al. (2004) }\end{array}$ & -- \\
\hline $\begin{array}{l}\text { X-ray absorption } \\
\text { spectroscopy }\end{array}$ & $\begin{array}{l}\text { Determination of } \\
\text { element coordination } \\
\text { structure, nearest } \\
\text { neighbors, and bond } \\
\text { distances in } \\
\text { contaminated sediment. }\end{array}$ & $\begin{array}{l}\text { Catalano et al. (2004); } \\
\text { Catalano et al. (2006) } \\
\text { Basic experimental } \\
\text { synchrotron } \\
\text { measurements are } \\
\text { modeled with FEFF, } \\
\text { FEFFIT, and IFEFFIT } \\
\text { (see below) to extract } \\
\text { molecular information. }\end{array}$ & -- \\
\hline Synchrotron diffraction & $\begin{array}{l}\text { Identification of mineral } \\
\text { structures } \\
\text { In sediment thin } \\
\text { sections. }\end{array}$ & $\begin{array}{l}\text { Catalano et al. (2004). } \\
\text { Mineral structures are } \\
\text { derived by application of } \\
\text { the FIT2D software (see } \\
\text { below). }\end{array}$ & -- \\
\hline $\begin{array}{l}\text { Cryogenic laser induced } \\
\text { fluorescence } \\
\text { spectroscopy (CLIFS) }\end{array}$ & $\begin{array}{l}\text { Vibronic spectra of } \\
\text { U(VI) in water and } \\
\text { solids to establish } \\
\text { molecular and } \\
\text { mineralogic } \\
\text { environment. }\end{array}$ & $\begin{array}{l}\text { Wang et al. (2004) (for } \\
\text { aqueous solutions); Wang } \\
\text { et al. (2005a) (for solids). } \\
\text { Data analysis is } \\
\text { performed using the } \\
\text { IGOR and Globals } \\
\text { programs (see below). }\end{array}$ & -- \\
\hline $\begin{array}{l}\text { Batch kinetic desorption } \\
\text { experiments }\end{array}$ & $\begin{array}{l}\text { Sediments are bathed in } \\
\text { electrolyte of known } \\
\text { composition and the } \\
\text { time-variant release of } \\
\text { contaminants and other } \\
\text { solid associated ions are } \\
\text { monitored by aqueous } \\
\text { phase analyses. }\end{array}$ & $\begin{array}{l}\text { Procedures vary as per } \\
\text { element and its concen- } \\
\text { tration. Examples include } \\
\text { Liu et al. (2003) (Cs-137); } \\
\text { Liu et al. (2004) (U); } \\
\text { McKinley et al. (2006) } \\
\text { (Sr-90). Kinetic rate laws } \\
\text { and rate constants are } \\
\text { calculated from the data } \\
\text { using microscopic, } \\
\text { diffusion based transport } \\
\text { models (See below). } \\
\text { Steady state values can be } \\
\text { used to establish } \\
\text { thermodynamic } \\
\text { parameters, such as the } \\
\text { solubility product of a } \\
\text { precipitated contaminant } \\
\text { phase (e.g., Ilton et al. } \\
\text { 2007). }\end{array}$ & -- \\
\hline
\end{tabular}




\begin{tabular}{|c|c|c|c|}
\hline Method & Analysis & Document Number & Procedure Title \\
\hline $\begin{array}{l}\text { Batch adsorption } \\
\text { experiments }\end{array}$ & $\begin{array}{l}\text { Sediments are bathed in } \\
\text { electrolyte of know } \\
\text { composition that has } \\
\text { been spiked with a } \\
\text { contaminant of interest. } \\
\text { The adsorption of the } \\
\text { contaminant is } \\
\text { monitored as a function } \\
\text { of pH, ionic strength, or } \\
\text { ion composition. }\end{array}$ & $\begin{array}{l}\text { Example procedures are } \\
\text { equilibrium -Turner et al. } \\
1996 \text { (U) and Zachara } \\
\text { et al. } 2002 \text { (Cs); kinetic- } \\
\text { Liu et al. } 2003 \text { (Cs), Liu } \\
\text { et al. } 2004 \text { (U), and } \\
\text { McKinley et al. } 2007 \text { (Sr). } \\
\text { Experimental results are } \\
\text { fitted with various } \\
\text { geochemical models } \\
\text { (MINTEQ; Geochemists } \\
\text { Workbench; GMIN; or } \\
\text { FITEQL see below) to } \\
\text { identify suites of } \\
\text { adsorption reactions (ion } \\
\text { exchange or surface } \\
\text { complexation). }\end{array}$ & -- \\
\hline Column experiments & $\begin{array}{l}\text { Sediment }(<2 \mathrm{~mm} \text { or } \\
<4 \mathrm{~mm}) \text { is packed into a } \\
\text { cylindrical plastic, glass, } \\
\text { or stainless steel column. } \\
\text { Electrolyte with or } \\
\text { without a contaminant } \\
\text { tracer is applied to the } \\
\text { column to study the } \\
\text { release (from } \\
\text { contaminated sediment) } \\
\text { or sorption/retardation } \\
\text { (for uncontaminated } \\
\text { sediments) of key } \\
\text { contaminants of concern. }\end{array}$ & $\begin{array}{l}\text { Qafoku et al. 2005. The } \\
\text { basic experimental data } \\
\text { that is in the form of } \\
\text { chemical concentration as } \\
\text { a function of leaching } \\
\text { volume of fluid, must be } \\
\text { modeled with various } \\
\text { commercial and research } \\
\text { codes to yield useable } \\
\text { information. CXTFIT is } \\
\text { used to fit physical } \\
\text { transport parameters such } \\
\text { as the dispersivity, while } \\
\text { other models are linked } \\
\text { with a solver of the } \\
\text { advective-dispersion } \\
\text { equation to describe } \\
\text { 1-dimensional reactive } \\
\text { transport. The reactive } \\
\text { transport models include a } \\
\text { commercial one (the } \\
\text { Geochemists Workbench) } \\
\text { and others assembled by } \\
\text { the research team } \\
\text { including the Distributed } \\
\text { Rate Model (DRM) and } \\
\text { the Dual Continuum } \\
\text { Model (DCM). These are } \\
\text { described below. }\end{array}$ & - \\
\hline
\end{tabular}




\begin{tabular}{|c|c|c|c|}
\hline Method & Analysis & Document Number & Procedure Title \\
\hline MINTEQA2 Version 4 & $\begin{array}{l}\text { Commercial software } \\
\text { used to calculate } \\
\text { aqueous speciation, } \\
\text { precipitation/dissolution, } \\
\text { and adsorption/ } \\
\text { desorption equilibria for } \\
\text { low to intermediate- } \\
\text { strength solutions. }\end{array}$ & $\begin{array}{l}\text { Code published by } \\
\text { Allison et al. } 1991 \text { and } \\
1998 \text { linked to a } \\
\text { thermodynamic data base } \\
\text { of our own synthesis (see } \\
\text { below). }\end{array}$ & -- \\
\hline Geochemists Workbench & $\begin{array}{l}\text { Commercial software to } \\
\text { calculate geochemical } \\
\text { equilibria, reaction } \\
\text { network modeling, and } \\
\text { reactive transport. }\end{array}$ & $\begin{array}{l}\text { Geochemists Workbench } \\
\text { Release 6. from Craig } \\
\text { Bethke, Hydrogeology } \\
\text { Program, University of } \\
\text { Illinois }\end{array}$ & -- \\
\hline CXTFIT & $\begin{array}{l}\text { Commercial software for } \\
\text { fitting column effluent } \\
\text { data. }\end{array}$ & Toride et al. (1999) & -- \\
\hline FITEQL (V 4.0) & $\begin{array}{l}\text { Commercial software } \\
\text { used to calculate } \\
\text { equilibrium constants } \\
\text { and their statistics for } \\
\text { aqueous, surface and } \\
\text { precipitated phases from } \\
\text { batch experimental data. }\end{array}$ & $\begin{array}{l}\text { Herbelin and Westall } \\
\text { (1999) }\end{array}$ & -- \\
\hline GMIN & $\begin{array}{l}\text { An equilibrium } \\
\text { geochemical model used } \\
\text { to calculate aqueous } \\
\text { speciation, precipitation/ } \\
\text { dissolution, and } \\
\text { adsorption desorption } \\
\text { equilibria for high ionic } \\
\text { strength solutions. } \\
\text { Maintained by PNNL. }\end{array}$ & Felmy (1995) & -- \\
\hline Spectral Fitting Software & $\begin{array}{l}\text { Commercial software } \\
\text { used to fit fluorescence } \\
\text { emission spectra on } \\
\text { U(VI) derived from } \\
\text { CLIFS analyses. The } \\
\text { fitting allows } \\
\text { determination of the } \\
\text { precise spectral } \\
\text { wavelengths and } \\
\text { deconvolutes spectral } \\
\text { signatures resulting from } \\
\text { multiple fundamental } \\
\text { species. }\end{array}$ & Beechem et al. (1991) & -- \\
\hline $\begin{array}{l}\text { Phase Identification for } \\
\text { Powder Diffraction } \\
\text { (JADE+, V 5) }\end{array}$ & $\begin{array}{l}\text { Commercial software } \\
\text { used to manipulate } \\
\text { powder diffraction files } \\
\text { are for comparison with } \\
\text { reference spectra in for } \\
\text { mineral identification. }\end{array}$ & $\begin{array}{l}\text { Materials Data Inc., } \\
\text { Livermore, CA; ICDD, } \\
\text { (2003) }\end{array}$ & -- \\
\hline
\end{tabular}




\begin{tabular}{|c|c|c|c|}
\hline Method & Analysis & "Document Number & Procedure Title \\
\hline $\begin{array}{l}\text { Reactive Transport } \\
\text { Modeling }\end{array}$ & $\begin{array}{l}\text { The Dual Continuum } \\
\text { Model (DCM) is used to } \\
\text { model the reactive } \\
\text { transport of contami- } \\
\text { nants 1-dimensional } \\
\text { laboratory columns and } \\
\text { in multidimensional field } \\
\text { simulations. The model } \\
\text { is a reaction-based } \\
\text { simulator and requires } \\
\text { significant } \\
\text { parameterization using } \\
\text { batch and column data, } \\
\text { and physical measure- } \\
\text { ments of sediment } \\
\text { characteristics. } \\
\text { Maintained by LANL. }\end{array}$ & $\begin{array}{l}\text { Lichtner et al. (2000); } \\
\text { Lichtner et al. (2001) }\end{array}$ & -- \\
\hline $\begin{array}{l}\text { Empirical Kinetic } \\
\text { Modeling }\end{array}$ & $\begin{array}{l}\text { The distributed rate } \\
\text { model (DRM) is used to } \\
\text { empirically describe } \\
\text { complex kinetic } \\
\text { desorption/dissolution } \\
\text { phenomena in sediment } \\
\text { that is controlled by } \\
\text { chemical kinetics or } \\
\text { diffuse mass transport. } \\
\text { The basic model } \\
\text { describes kinetic } \\
\text { phenomena using a } \\
\text { statistical distribution of } \\
\text { first order rate constants. } \\
\text { Maintained at PNNL. }\end{array}$ & Culver et al. (1997) & -- \\
\hline $\begin{array}{l}\text { Surface Complexation } \\
\text { Model }\end{array}$ & $\begin{array}{l}\text { The surface complex- } \\
\text { ation model (SCM) is } \\
\text { used to describe the } \\
\text { surface chemical } \\
\text { reactions of U(VI) that } \\
\text { are responsible for its } \\
\text { adsorption to vadose } \\
\text { zone and aquifer } \\
\text { sediments. Maintained } \\
\text { by USGS. }\end{array}$ & Davis et al. (2004) & -- \\
\hline
\end{tabular}




\begin{tabular}{|c|c|c|c|}
\hline Method & Analysis & Document Number & Procedure Title \\
\hline $\begin{array}{l}\text { Thermodynamic Data } \\
\text { Base }\end{array}$ & $\begin{array}{l}\text { A large thermodynamic } \\
\text { data base is maintained } \\
\text { and constantly updated } \\
\text { based on literature } \\
\text { advances. The data base } \\
\text { describes stability } \\
\text { constants for aqueous } \\
\text { complexes and solubility } \\
\text { products for precipitated } \\
\text { phases relevant to S\&T } \\
\text { research and issues. } \\
\text { This data base is used in } \\
\text { almost every S\&T } \\
\text { geochemical study. } \\
\text { There are many } \\
\text { hundreds of entries in } \\
\text { the data base for a } \\
\text { variety of contaminants } \\
\text { that is used in } \\
\text { MINTEQA@; } \\
\text { Geochemists } \\
\text { Workbench, and all of } \\
\text { the reactive transport } \\
\text { codes. Maintained at } \\
\text { PNNL. }\end{array}$ & $\begin{array}{l}\text { The data base relies on } \\
\text { the following and many } \\
\text { other sources: Grenthe } \\
\text { et al. } 1992 \text { (U); } \\
\text { Guillaumount et al. } 2003 \\
\text { (U); Rard (1999) (Tc). }\end{array}$ & -- \\
\hline $\begin{array}{l}\text { Saturated Hydraulic } \\
\text { Conductivity }\end{array}$ & -- & Wietsma et al. (2009) & $\begin{array}{l}\text { Saturated hydraulic } \\
\text { conductivity using constant } \\
\text { flux, constant head, and } \\
\text { falling head methods. }\end{array}$ \\
\hline Multistep retention & -- & Tuli et al. (2001) & $\begin{array}{l}\text { Determination of water } \\
\text { saturation as a function of } \\
\text { capillary pressure by } \\
\text { imposing a series of } \\
\text { increasing air pressures on } \\
\text { cores. }\end{array}$ \\
\hline
\end{tabular}

*PNNL-AGG referenced procedures are from PNNL’s Applied Geochemistry Group

\section{B.1 References}

Allison JD, DS Brown, and KJ Novo-Gradac. 1991. MINTEQA2/PRODEFA2, A Geochemical Assessment Model for Environmental Systems: Version 3.0 User's Manual. U.S. Environmental Protection Agency, Washington, D.C.

Allison JD, DS Brown, and KJ Novo-Gradac. 1998. MINTEQA2/PRODEFA2, A Geochemical Assessment Model for Environmental Systems: User Manual Supplement for Version 4.0. U.S. Environmental Protection Agency, Washington, D.C.

Beechem JM, E Gratton, and WW Mantulin. 1991. Globals Unlimited. UIUC Publication. 
Catalano JG, JP McKinley, JM Zachara, SC Smith, and GE Brown, Jr. 2006. "Changes in Uranium Speciation Through a Depth Sequence of Contaminated Hanford Sediments." Environ. Sci. Technol. 40(8), 2517-2524.

Catalano JG, SM Heald, JM Zachara, and GE Brown, Jr. 2004. "Spectroscopic and Diffraction Study of Uranium Speciation in Contaminated Vadose Zone Sediments from the Hanford Site, Washington State." Environ. Sci. Technol. 38:2822-2828.

Culver TB, SP Hallisey, D Sahoo, JJ Deitsch, and JA Smith. 1997. "Modeling the Desorption of Organic Contaminants from Long-Term Contaminated Soil Using Distributed Mass Transfer Rates." Environ. Sci. Technol. 31:1581-1588.

Davis JA, DE Meece, M Kohler, and GP Curtis. 2004. "Approaches to Surface Complexation Modeling of Uranium(VI) Adsorption on Aquifer Sediments." Geochim. Cosmochim. Acta 68:3621-3641.

Felmy AR. 1995. "GMIN. A Computerized Chemical Equilibrium Program Using a Constrained Minimization of the Gibbs Free Energy: Summary Report." In Chemical Equilibrium and Reaction Models (eds. RH Loeppert, AP Schwab, and S Goldberg) pp. 377-407, Soil Science Society of America.

Fredrickson JK, JM Zachara, DW Kennedy, RK Kukkadapu, JP McKinley, SM Heald, C Liu, and AE Plymale. 2004. "Reduction of $\mathrm{TcO}^{4-}$ by Sediment-Associated Biogenic Fe(II)." Geochim. Cosmochim. Acta 68(15):3171-3187.

Grenthe I, J Fuger, RJM Konings, RJ Lemire, AB Muller, C Nguyen-Trung, and H Wanner. 1992. Chemical Thermodynamics of Uranium. North-Holland, Amsterdam.

Guillaumount R, T Fanghanet, V Neck, J Fuger, DA Palmer, I Grenthe, and MH Rand. 2003. Update on the Chemical Thermodynamics of Uranium, Neptunium, Plutonium, Americium, and Technetium. Elsevier.

Hammersley AP. 1997. FIT2D: An Introduction and Overview. Internal Report ESRF97HA02T; European Synchrotron Radiation Facility, Grenoble, France.

Herbelin A and J Westall. 1999. FITEQL: A Computer Program for Determination of Chemical Equilibrium Constants from Experimental Data, Version 4.0. Report 99-01. Oregon State University, Corvallis, Oregon.

ICDD. 2003. JCPDS Powder Diffraction Files, PDF. International Centre for Diffraction Data (ICDD), Newtown, Square, Pennsylvania.

Ilton ES, C Liu, W Yantasee, Z Wang, D Moore, and JM Zachara. 2006. "The Effect of Carbonate on the Dissolution of Synthetic Na-Boltwoodite." Geochimica et Cosmochimica Acta 70(19):4836-4849.

Kukkadapu RK, JM Zachara, JK Fredrickson, and DW Kennedy. 2004. "Biotransformation of Two-Line Silica-Ferrihydrite by a Dissimilatory Fe(III)-Reducing Bacterium: Formation of Carbonate Green Rust in the Presence of Phosphate." Geochim. Cosmochim. Acta 68(13):2799-2814.

Lichtner PC. 2001. FLOTRAN: User's Manual. Report No. LA-UR-02-2349, Los Alamos National Laboratory, Los Alamos, New Mexico. 
Lichtner PC. 2000. "Critique of Dual Continuum Formulations of Multicomponent Reactive Transport in Fractured Porous Media, Dynamics of Fluids in Fractured Rock." Geophys. Monograph 122:281-298.

Liu C, JM Zachara, W Yantasee, PD Majors, and JP McKinley. 2006. "Microscopic Reactive Diffusion of Uranium in the Contaminated Sediments at Hanford, USA: Characterization and Modeling." Water Resources Research, Vol. 42, W12420, doi:10.1029/2006WR005031.

Liu C, JM Zachara, O Qafoku, JP McKinley, SM Heald, and Z Wang. 2004. "Dissolution of Uranyl Microprecipitates in Subsurface Sediments at Hanford Site, USA." Geochim. Cosmochim. Acta 68(22):4519-4537.

Liu C, JM Zachara, SC Smith, JP McKinley, and CC Ainsworth. 2003. "Desorption Kinetics of Radiocesium from Subsurface Sediments at Hanford Site, USA." Geochim. Cosmochim. Acta 67(16):2893-2912.

McKinley JP, JM Zachara, SC Smith, and C Liu. 2007. “Cation Exchange Reactions Controlling Desorption of ${ }^{90} \mathrm{Sr}^{2+}$ from Coarse-Grained Contaminated Sediments from the Hanford Formation, Washington." Geochimica et Cosmochimica Acta 71(2):305-325.

McKinley JP, JM Zachara, C Liu, and SC Heald. 2006. "Precipitation of Waste Uranium as a Uranyl Silicate in Microfractures." Geochimica et Cosmochimica Acta 70(8):1873-1887.

McKinley JP, RJ Serne, JM Zachara, CJ Zeissler, and RM Lindstrom. 2001. "The Distribution and Retention of ${ }^{137} \mathrm{Cs}$ in Sediments at the Hanford Site, Washington." Environ. Sci. Technol. 35:3433-3441.

Newville M. 2001a. "IFEFFIT: Interactive XAFS Analysis and FEFF Fitting." J. Synch. Rad. 8:322-324.

Newville M. 2001b. "EXAFS Analysis Using FEFF and FEFFIT.” J. Synch. Rad. 8:96-100.

Qafoku NP, JM Zachara, C Liu, PL Gassman, OS Qafoku, and SC Smith. 2005. "Kinetic Desorption and Sorption of U(VI) During Reactive Transport in a Contaminated Hanford Sediment." Environ. Sci. Technol. 39:3157-3165.

Rard JA, MH Rand, G Anderegg, and H Wanner. 1991. Chemical Thermodynamics of Technetium, Chapter 3; (MCA Sandino and E Osthols, eds.), Elsevier, The Netherlands, Amsterdam, pp. 544.

Toride N, FJ Leij, and MT van Genuchten. 1999. The CXTFIT Code for Estimating Transport Parameters from Laboratory or Field Tracer Experiments. U.S. Salinity Laboratory.

Tuli, A, MA Denton, JW Hopmans, T Harter, and JLMacIntyre. 2001. Multi-step Outflow Experiment: From Soil Preparation to Parameter Estimation. Department of Land, Air, and Water Paper. No 100037. University of California, Davis, California.

Turner GD, JM Zachara, JP McKinley, and SC Smith. 1996. "Surface-Charge Properties and $\mathrm{UO}_{2}{ }^{2+}$ Adsorption of a Subsurface Smectite.” Geochim. Cosmochim. Acta 60:3399-3414.

Wang Z, JM Zachara, PL Gassman, O Qafoku, and J Catalano. 2005a. "Fluorescence Spectroscopy of U(VI)-Silicates and U(VI)-Contaminated Hanford Sediment." Geochim. Cosmochim. Acta 69(6):1391-1403. 
Wang Z, JM Zachara, JP McKinley, SC Smith, and SM Heald. 2005b. "Cryogenic Laser Induced U(VI) Fluorescence Studies of a U(VI) Substituted Natural Calcite: Implications to U(VI) Speciation in Contaminated Hanford Sediments." Environ. Sci. Technol. 39:2651-2659.

Wang Z, JM Zachara, W Yantasee, PL Gassman, C Liu, and AG Joly. 2004. "Cryogenic Laser Induced Fluorescence Characterization of U(VI) in Hanford Vadose Zone Pore Waters." Environ. Sci. Technol. 38(21):5591-5597.

Webb SM. 2005. "SIXPack: A Graphical User Interface for XAS Analysis Using IFEFFIT.” Phys. Scr. T115, 1011-1014.

Wietsma, TW, M Oostrom, MA Covert, TW Queen, and MJ Fayer. 2009. “An Automated Apparatus for Constant Flux, Constant Head, and Falling Head Hydraulic Conductivity Measurements." Soil Science Society of America J. (In Press).

Zachara JM, SC Smith, C Liu, JP McKinley, RJ Serne, and PL Gassman. 2002. "Sorption of Cs ${ }^{+}$to Micaceous Subsurface Sediments from the Hanford Site, USA.” Geochim. Cosmochim. Acta 66:193-211.

Zeissler CJ, RM Lindstrom, and JP McKinley. 2001. "Radioactive Particle Analysis by Digital Autoradiography." J. Radioanal. Nuclear Chem. 248(2):407-412. 


\section{Distribution}

No. of

Copies

\section{Local Distribution}

DOE Richland Operations Office

DOE Public Reading Room (2) H2-53

\section{Pacific Northwest National Laboratory}

L. R. Burns

K6-94

R. D. Daudt

K7-28

R. J. Fellows

K2-21

N. J. Fix

K9-75

J. S. Fruchter

K6-96

R. E. Peterson

K6-75

N. A. Sargent

K9-75

J. E. Smith

J2-56

V. R. Vermeul

K6-96

D. M. Wellman

K3-62

Hanford Technical Library (2)

P8-55

Distr.1 


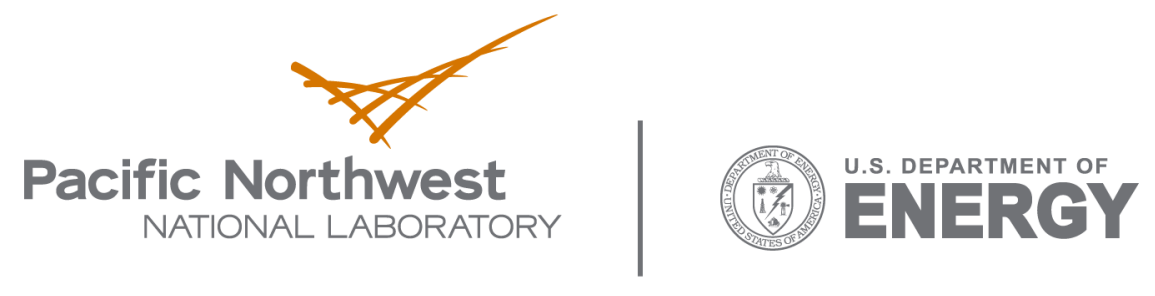

902 Battelle Boulevard

P.O. Box 999

Richland, WA 99352

1-888-375-PNNL (7665)

www.pnl.gov 